\title{
APROXIMACIÓN A LA «BAJA LABORAL» EN EL SIGLO XVIII. EL «PUNCTO DE QUARTANARIO»EN LA CATEDRAL BURGALESA
}

\author{
POR \\ Francisco José SANZ DE LA HiguERA \\ I.E.S. «Torreblanca» (Sevilla)
}

\section{RESUMEN}

Los componentes del Cabildo catedralicio tenían el privilegio añadido de gozar de las atenciones profesionales de, al menos, un médico, contratado en exclusiva para el cuidado de su salud. Las Actas capitulares anotan sus bajas por enfermedad, los diagnósticos, tratamientos y particularidades de sus patologías y las circunstancias que acompañaban al proceso de su «Punto de Quartanario». Las certificaciones de los galenos eran sometidas a la aprobación de sus compadres, tanto para la primera ausencia como para las posteriores ampliaciones.

PALABRAS CLAVE: Cabildo, Catedral, Médico, Quartanario, Enfermedad

\section{APPROACH TO THE «SICK LEAVE» IN THE EIGHTEENTH CENTURY. THE «PUNTO DE QUARTANARIO»IN IN THE CATHEDRAL OF BURGOS}

\begin{abstract}
The members of the Cathedral Chapter had the privilege added of enjoying professional attentions of, at least, a doctor, exclusively contracted to take care of their health. The capitulars acts record their sick leave, diagnoses, treatments and particularities of their pathologies and the circumstances that accompanied the process of their «Punto de Quartanario». The medical certificates were subjected to the approval of their compadres, for the first absence as well as for the subsequent ones.
\end{abstract}

KEY WORDS: Chapter, Cathedral, Doctor, Quartanario, Illness

Recibido/Received 19-07-2010

Aceptado/Accepted 04-01-2012 
«...devuelves la vista a los ciegos, y la facultad de andar a los cojos; limpias a los leprosos, y expulsas espíritus inmundos y demonios; devuelves la salud a los que se encuentran aquejados de largas enfermedades y resucitas a los muertos».

Evangelios apócrifos.

El Cabildo de la Catedral de Burgos cuenta, en lo tocante a su asistencia médica, con brillantes estudios efectuados por el doctor López Gómez. ${ }^{1}$ En el panorama español aparecen otras obras de singular interés. ${ }^{2}$ Empero, la cuestión

\footnotetext{
${ }^{1}$ López Gómez, J. M. 1993. «Los médicos del Cabildo catedralicio de Burgos en el siglo XVIII». Boletín de la Institución Fernán González (BIFG) 207: 411-448, López Gómez, J. M. 1996. Cirugía ilustrada en Burgos: la figura y la obra de José Victoriano Gómez. (1773-1819), Burgos, Institución Fernán González - Academia Burgense de Historia y Bellas Artes. López Gómez, J. M. 1999. «Los profesionales sanitarios de la ciudad de Burgos en 1740». BIFG 218: 20-31. Véase también Sanz de la Higuera, F. J. (2009). «La temible f(r)actura de la muerte. Fallecer en el Burgos del Setecientos». Cuadernos de Investigación Histórica 23: 251-283 y Sanz de la Higuera, F. J. 2009. «Aproximación a la locura en el Setecientos burgalés. Cerebros, humores y economías en desequilibrio». Investigaciones Históricas 29: 41-68.

${ }^{2}$ Citados sin un ánimo exhaustivo, descuellan Sánchez Granjel, L. 1979. La medicina española del siglo XVIII, Salamanca, Peset Reig, J. L. 2008. «Clérigos y médicos ante la muerte», Vía Spiritus, 15: 23-34, Lafuente, A., Puerto Sarmiento, F. J. y Calleja Folguera, M. C. 1988. «Los profesionales de la sanidad tras su identidad en la Ilustración española», en Sánchez Rón, J. M. (Ed.), Ciencia y Sociedad en España: de la Ilustración a la Guerra Civil: 73-74, Madrid, Granjel. M. 2002: «Médicos y cirujanos en Extremadura a finales del siglo XVIII». Dynamis 22: 151-187, Moretón Alonso, M. 1993. Las profesiones sanitarias en Castilla y León (siglo XVIII). Análisis sociológico y estadístico, Valladolid, Sáez Gómez, J. M. y Marset Campos, Pedro. 1993. «Profesionales sanitarios en la Murcia del siglo XVIII. Número, evolución y distribución». Asclepio 45/2: 71-101, Fernández Doctor, A. 1997. «Médicos y cirujanos de Zaragoza en la Edad Moderna». Dynamis 17:141-164, Ortiz Gómez, T., Quesada Ochoa, C. y Astrain Gallart, M. 1994. «El Catastro de Ensenada como fuente para el estudio de las profesiones sanitarias en la España del siglo XVIII», en Carrillo Martos, J. L. y Olagüe de Ros, G. (Eds.), Actas del 33 Congreso Internacional de Historia de la Medicina: 712-713, Sevilla y 1995. «Profesionales de la salud en la Almería del siglo XVIII, según el Catastro de Ensenada», Actas del II Congreso de Historia de Andalucía, Historia Moderna, tomo I: 511-520, Córdoba, León Sanz, P. 2002. «La consulta médica. Una práctica de la medicina en el siglo XVIII». Dynamis 22: 279-302, Gómez Díaz, D. y Gómez Díaz, M. J. 2003. «Almería ante el contagio. La práctica sanitaria del siglo XVIII». Dynamis 23: 221-244, Perdiguero Gil, E. 2002. «»Con medios humanos y divinos»: la lucha contra la enfermedad y la muerte en Alicante en el siglo XVIII». Dynamis 22: 121-150, Perdiguero Gil, E. y Bernabeu Mestre, J. 1995.«La asistencia médica pública en el Alicante del siglo XVIII: los médicos de la Ciudad». Canelobre 29/30: 165-176, García Guerra, D. 1985. «El ejercicio médico en el Hospital Real de Santiago en el siglo XVIII», en Peset Reig, J. L. (Ed.), La ciencia moderna y el conocimiento del Nuevo Mundo: 379-394, Rojo Vega, A. 1994. «Los médicos vallisoletanos del siglo XVII. Status y consideración social», en Historia y Medicina en España. Homenaje al Profesor Luis S. Granjel: 127-131, Valladolid en el ámbito español. En el ámbito internacional, Ramsey, M. 1988. Professional and popular medicine in France, 1770-1830, Cambridge, Gelfand, T. 1980. Professionalizing Modern Medicine, Londres, Brockliss, L. y Jones, C. 1997. The Medical World of Early Modern France, Cambridge, Lindemann, A. M. 1996. Health and Healing in Eighteenth Century Germany, Baltimore y Londres y Chaussinand-Nogaret, G. 1977. «Médecins, médecine et société en France aux XVIII ${ }^{\mathrm{e}}$ et XIX ${ }^{\mathrm{e}}$ siècles». Annales ESC 32/5: 849-857.
}

Hispania Sacra, LXIV

130, julio-diciembre 2012, 661-719, ISSN: 0018-215X, doi: 10.3989/hs.2012.020 
de cuántos eran, cómo habían llegado a serlo y a qué se dedicaban en su labor profesional no está reñida con el análisis de qué tipo de patologías se encargaban de tratar, cuáles eran los diagnósticos que pergeñaban y qué terapias recomendaban a los enfermos. Son raros los memoriales, o la documentación en general, a través de los que podamos adentrarnos, de primera mano, en el contenido de los análisis que los médicos y cirujanos ${ }^{3}$ efectuaban sobre sus pacientes, fueran éstos clérigos catedralicios o parroquiales, locos de atar, ${ }^{4}$ particulares o trabajadores del Hospital del Rey.

Las Actas capitulares de la Catedral de Burgos y el registro 108 de su sección Libros recogen abundantes expedientes e informaciones sobre las enfermedades de los capitulares de la Catedral burgalesa. ${ }^{5}$ Algunos retazos de información en el Ayuntamiento y en algunas parroquias de la ciudad permiten constatar la especificidad del «Puncto de Quartanario»-PQ en lo sucesivocatedralicio y su carácter innovador y precocidad.

Para la realización de este trabajo se ha efectuado un rastreo intensivo y sistemático, de tercer nivel, ${ }^{6}$ en las Actas del Cabildo catedralicio, en las Actas de gobierno del Concejo y en otras instituciones de la ciudad. Los libros de fábrica de la Catedral y los «sacramentales» de las parroquias, en especial los legajos de difuntos, permiten trazar una perspectiva ecológica del climax imperante en la ciudad en lo tocante a las vicisitudes climáticas y epidémicas. El volumen de combustibles consumidos en la Catedral y el devenir de la mortalidad en la ciudad se configuran, en la práctica, como barómetros circunstanciales que posibilitan auscultar la presión a que se hallaba sometida la población y la producción agraria en el siglo XVIII.

\footnotetext{
${ }^{3}$ Desarrollaran sus quehaceres profesionales para el Cabildo catedralicio en exclusiva, trabajaran para la Ciudad (Concejo) y los Hospitales o fueran de práctica libre en otros momentos de su vida cotidiana. Véase Valenzuela Candelario, J. y Rodríguez Ocaña, E. 1992. «Lugar de enfermos, lugar de médicos. La consideración del hospital en la medicina española, siglos XVIII a XX», en Montiel, L. (Coord.), La salud en el estado de bienestar: análisis histórico: 107-131, Madrid. Véase igualmente Peset Reig, L. L. (Dir.). 2002. Historia de la ciencia y de la técnica en la corona de Castilla, IV, Siglo XVIII: 215-237, Valladolid y Riera, J. 1980. José Masdevall y la medicina española ilustrada. (Enseñanza, epidemia y guerra a finales del siglo XVIII), Valladolid.

${ }^{4}$ López Gómez, J. M. 2005. «Razón y locura en el Burgos de la Ilustración. El caso del marqués de Lorca», en Estudios de Historia y Arte. Homenaje al profesor D. Alberto C. Ibáñez Pérez: 177-181, Burgos y López Gómez, J. M. 1996. Salud y enfermedad en el Burgos de la segunda mitad del siglo XVIII, Burgos.

${ }^{5}$ Archivo Capitular de la Catedral de Burgos (ACC). Actas Capitulares (AC). Libros de Registro (LR) diferentes y Cabildos ordinarios y Libro 108 que serán citados oportunamente en el discurso del texto.

${ }^{6}$ Chaunu, P. 1973.«Un nouveau champ pour l'histoire sérielle: le quantitatif au troisième niveau», Méthodologie de l'histoire et des sciencies humaines, Mélanges en l'honneur de Fernand Braudel: tomo II, 105-125, París y González Cruz, D. 1993. Religiosidad y ritual de la muerte en la Huelva del siglo de la Ilustración: 21-22, Huelva.
} 
LA «BAJA LABORAL» COMO PROBLEMA CONCEPTUAL

Uno de los más letales cánceres que puede sufrir un investigador de historia en el proceso de reconstrucción del pretérito es el presentismo, ${ }^{7}$ patología que suele estar acompañada de una carencia casi absoluta de objetividad y de un exacerbado bagaje de positivismo acrítico. El transponer a épocas anteriores a la nuestra conceptos, prácticas y/o actitudes habituales en la sociedad en que vivimos es un error monumental que impregna el quehacer del historiador con un pecado nefando imperdonable: la falta de sentido común.

Denominar «baja laboral» al «Puncto de Quartanario» que se estilaba en el Cabildo de la Catedral de Burgos en el siglo XVIII puede parecer a algunos un presentismo irregular, lamentable e insostenible. Empero, visto desde una perspectiva estricta, lo que hacían los prebendados catedralicios burgaleses, avalados por las «Zertificaziones Juradas» de médicos y cirujanos, era sencillamente solicitar a la institución en la que ejercían sus actividades profesionales uno o dos meses de permiso para no concurrir a los Cabildos, a los empleos y a los oficios divinos, al Coro en definitiva, con la certeza de que iban a percibir íntegramente sus prebendas.

Los prebendados disponían de un instrumento «sui generis», se habían dotado como institución de un mecanismo ingenioso, que posibilitaba unas relaciones laborales privilegiadas, no alcanzadas por ninguna otra categoría socio-profesional de la época. Las hilanderas, pobres de solemnidad, jornaleros, labradores y hortelanos, maestros y oficiales artesanos, comerciantes, burócratas y las gentes de los servicios públicos únicamente obtenían ingresos si desarrollaban sus quehaceres cotidianos. En caso contrario, el dinero no acudía a sus talegas por sí solo, porque no se había cumplido con el trabajo y, aunque estuvieran enfermos, nadie les pagaba.

En el Cabildo catedralicio de Burgos, los aquejados de patologías graves percibían sus prebendas si cumplimentaban rigurosamente el protocolo necesario. El proceso completo del «Puncto de Quartanario» transitaba por tres filtros rigurosos que se solapaban en la práctica pero tenían una autonomía y unas garantías plenas.

En primera instancia, el enfermo acudía al médico, fuera éste el del Cabildo, de la Ciudad o de otras entidades urbanas en que residiera, o a un cirujano de prestigio, titular de un hospital de su localidad, que le exploraba, diagnosticaba, prescribía soluciones a sus males y firmaba el correspondiente certificado jurado que lo avalaba.

${ }^{7}$ De ello nos advertía, por ejemplo, Saavedra Fernández, P. 1979. Economía rural antigua de la montaña lucense: el Concejo de Burón: 51, Santiago de Compostela, cuando enfatizaba sobre el grave error que supone «transponer nuestra mentalidad -la mentalidad capitalista- a un mundo bastante distinto».

Hispania Sacra, LXIV

130, julio-diciembre 2012, 661-719, ISSN: 0018-215X, doi: 10.3989/hs.2012.020 
En segundo término, el prebendado acudía al Cabildo, con los papeles en regla y solicitaba que se admitiera formalmente su situación clínica. Previamente se había dado de alta entre los afectados por los achaques de salud en el llamado «Puncto de enfermo».

En tercer lugar, el Cabildo, reunido de manera ordinaria -como hacía los lunes y los viernes- sometía a debate y a votación, por el democrático sistema del reparto de las habas, ${ }^{8}$ su opinión sobre si era aceptable que estuviera uno o dos meses de «baja». Fueron muy pocas las ocasiones en las que se denegó el «Puncto de Quartanario» a un capitular. Cuando ocurría era por falta de documentos acreditativos o por una evidente intencionalidad fraudulenta en los solicitantes. Las «prórrogas», para una o dos mensualidades, para dentro o para fuera de la ciudad, seguían el mismo procedimiento.

En el tratamiento de este asunto contamos con varias aportaciones de excepcional interés a la hora de auscultar la existencia de fórmulas de solidaridad entre los componentes de los Cabildos, tanto de la Iglesia Metropolitana como de la universidad de parroquias. Descuellan con luz propia las reflexiones de Benito Aguado para Vitoria, ${ }^{9}$ de Domínguez Ortiz para Canarias, ${ }^{10}$ de Villacorta Rodríguez para León, ${ }^{11}$ de Canovas Botía para Murcia, ${ }^{12}$ de Quintana Andrés para Canarias, ${ }^{13}$ de Morgado García para Cádiz ${ }^{14}$ o de García-Cuevas Ventura para Córdoba. ${ }^{15}$

\footnotetext{
${ }^{8}$ Sobre los sistemas de votación en los Cabildos catedralicios véase, citados sin un ánimo exhaustivo, Quintana Andrés, P. C. 2003. A Dios rogando y con el mazo dando. Fe, poder y jerarquía en la Iglesia canaria. El Cabildo Catedral de Canarias entre 1483-1820: 165-170, Las Palmas de Gran Canarias, Cabeza Rodríguez, A. 1997. La vida en una Catedral del Antiguo Régimen: 54-55, Palencia, Canovas Botía, A. 1994. Auge y decadencia de una institución eclesial: el Cabildo Catedral de Murcia en el siglo XVIII. Iglesia y Sociedad: 199-202, Murcia, Villacorta Rodríguez, T. 1974. El Cabildo Catedral de León. Estudio histórico-jurídico, siglos XIII-XIX: 306-308, León, Sánchez González, R. 2000. Iglesia y sociedad en la Castilla Moderna: el Cabildo catedralicio de la Sede primada (siglo XVII): 47-48, Cuenca, Beltrán Almazán, C. y Toledano Galera, J. 1988. «El Cabildo de la iglesia Catedral de Jaén en el siglo XVI. Organización y funcionamiento». Boletín de Estudios Giennenses 134: 56-57 (31-57) y Sanz de la Higuera, F. J. 2005. «Cebada, mulas, caballos, carruajes y habas. La Catedral de Burgos en el Setecientos». Hispania Sacra 116: 559-588.

${ }^{9}$ Benito Aguado, M. T. 2001. La sociedad vitoriana en el siglo XVIII: el clero, espectador y protagonista: 226-229, Bilbao.

10 Domínguez Ortiz, A. 1964. «Absentismo eclesiástico en Canarias». Anuario de Estudios Atlánti$\cos 10: 235-247$.

11 Villacorta Rodríguez, T. 1974. «Causas que eximen de residencia y asistencia (...) c) Enfermos y convalecientes», El Cabildo Catedral de León. Estudio histórico-jurídico, siglos XII-XIX: 266-269, León.

12 Canovas Botía, A. 1994: 212-214.

${ }^{13}$ Quintana Andrés, P. C. 2003: 36-37, 45-51, 69, 88-96, 97-98, 102-104, 106, 123, 262-265, 410 y 424 y del mismo autor 2004. Finis gloriae mundi. Ideología y sociedad en Canarias. Los prebendados del Cabildo Catedral durante el Antiguo Régimen (1483-1820): 38-40, Bilbao.

14 Morgado García, A 1989. Iglesia y sociedad en el Cádiz del siglo XVIII: 101, Cádiz.

15 García-Cuevas Ventura, J. 1996.El Cabildo catedralicio cordobés desde la Revolución a la Restauración (1788-1882): 36-37, Córdoba.
} 
La profesora María Teresa Benito Aguado plantea la existencia de «bajas por enfermedad», en que el canónigo «acreditaba mediante certificado médico estar impedido para desempeñar sus funciones», es decir, estar presente en el Coro, circunstancia que no mermaba sus prebendas ni le expulsaba de su «empleo», «no quedaban desamparados en la enfermedad, en la vejez, ni en la pobreza, aunque esto supusiera un aumento de trabajo para los que todavía eran jóvenes y sanos» -véase nota 9-.

Esta solidaridad, auténtico seguro de vida profesional, era, en la práctica, un «do ut des» a caballo entre el presente y el futuro. Los capitulares rubricaban con el «nihil obstat» de las habas las «bajas laborales», sabedores de que, tarde o temprano, cada uno de ellos podría necesitar del auxilio por jubilación o por cesación temporal de actividades por causas clínicas.

Domínguez Ortíz, en 1964, en su trabajo «Absentismo eclesiástico en Canarias», perfilaba algunas problemáticas esenciales del proceder y las conductas del clero en la Iglesia antiguo-regimental canaria, en particular, y castellana, en general. Pedro C. Quintana Andrés se refiere en múltiples ocasiones a las enfermedades de los miembros del Cabildo, a la asistencia de un médico y a la colocación en situación de «patitur por culpa de una enfermedad o estar retenido por causa mayor en su posada» -véase nota 10-.

En los Reales Ejércitos, la oficialidad y la tropa aquejada de disfunciones ocasionadas por la barbarie de los conflictos o por sus particulares afecciones clínicas eran relajados en el servicio, en sus domicilios particulares o en los cuarteles, o depuraban sus patologías en las instituciones hospitalarias, o eran enviados, ambos, a las unidades de inválidos, donde estaban obligados a cumplir con los quehaceres que se les imponían hasta la licencia absoluta. También en estas unidades nos topamos con que la tropa era remitida a los hospitales y la oficialidad a sus viviendas o acuartelamientos, bajo la atenta mirada de médicos y cirujanos militares o civiles. ${ }^{16}$

El resto de la población carecía de cobertura institucional. En las «quadras» de los hospitales o en las alcobas de las viviendas particulares no se ganaban los salarios imprescindibles para el mantenimiento cotidiano. El talante avanzado y progresivo de la «baja laboral» habilitada en el Cabildo catedralicio burgalés chocaba diametralmente con las problemáticas surgidas en el Concejo o entre los médicos que atendían a los capitulares. Así, un empleado del Ayuntamiento,

${ }^{16}$ Véase a este respecto López Gómez, J. M. 1997. «La asistencia sanitaria a militares enfermos en el Burgos del último tercio del siglo XVIII». BIFG 21: 245-272, Riera Palmero, J. 1974. «Organización hospitalaria militar en la España ilustrada. (Las «Ordenanzas» de 1739)» Asclepio 26-27: 115-134, Alzate Echeverri, A. A. 2008. «Militares, marineros y pobres enfermos. Contribución a la historia del Hospital de San Juan de Dios de Cartagena de Indias (siglo XVIII)». Asclepio 60: 203-236, y Sanz de la Higuera, F. J. 2005. «Obras en Barrantes (1747-1750)». BIFG 230: 115-147. 
que se hallaba «Sumamente enfermo», se debatió en la angustia, la frustración y la impotencia, dado que fue tratado «en sus ausencias y enfermedades sin llevar salario ninguno ni ayuda de costa». ${ }^{17}$

Los médicos que atendían a los capitulares tenían serios problemas para acogerse ellos mismos a la «baja laboral». En abril de 1788, un memorial del doctor Félix Antón, titular del Cabildo catedralicio, exponía que llevaba «gustosamente en su servicio veinte y cinco años y desea continuarle hasta el fin de sus días; pero para prorrogarles lo más que sea posible, en estado de asistir a V. S., necesita ya de algún alivio por estar mui trabajado y en la edad de sesenta y ocho años».18 «QUARTANAS», «TERCIANAS» Y OTRAS PATOLOGÍAS SUFRIDAS POR EL CLERO CATE-
DRALICIO BURGALÉS EN EL SETECIENTOS

Para el siglo XVIII, los gráficos I y II, merced al rastreo intensivo efectuado en las Actas Capitulares, muestran la situación de los prebendados catedralicios solicitantes del «Puncto de Quartanario». Las variaciones responden a las vicisitudes climáticas y epidémicas que asolaban las ciudades castellanas en el Antiguo Régimen, aunque también hay que considerar otras etiologías, como las enfermedades ocasionadas por los desequilibrios en la dieta (gota) y el paludismo generado por las particularidades del trazado urbano burgalés (tercianas y cuartanas).

En el gráfico I se aprecia un proceso de crecimiento gradual -a veces más efervescente, otras más pausado- en las concesiones del «Punctto de Quarttanario» a lo largo del siglo XVIII. Uno de los problemas es saber qué patologías se encuentran en la base de tal inflación y otro, más espinoso aún, conocer la respuesta de la institución ante las enfermedades y padecimientos de los prebendados, con el telón de fondo del acceso a los combustibles, carbón y leña, los excesos en la dieta, en la ingesta alimenticia cotidiana -sobre todo por el abuso del carnero- y las repercusiones medioambientales de la escorrentía permanente que caracterizaba, junto con el «fetor» sistemático de calles y casas, ${ }^{19}$

${ }^{17}$ Archivo Municipal de Burgos (AMB). Actas de Gobierno. Regimiento del 13 de abril de 1711, folio 112. Las circunstancias son extensivas a los restantes trabajadores del Concejo.

${ }_{18}$ Archivo Capitular de la Catedral de Burgos (ACB). Actas Capitulares (AC). Libro de Registro 119. Cabildo del 14 de abril de 1788, folios 182-183. En lo sucesivo ACCB. AC. LR. Don Félix Antón falleció en diciembre de 1807, a la edad de 87 años. Archivo Diocesano de Burgos (ADB). San Lesmes. Defunciones. Legajo $11^{\circ} .1^{\circ}$ de diciembre de 1807, folio 117.

19 Véase a este respecto Cipolla, C. M. 1993. Contra un enemigo mortal e invisible, Barcelona, Crítica, y Carmona García. J. I. 2000. Crónica urbana del malvivir (s. XIV-XVII). Insalubridad, desamparo y hambre en Sevilla, Sevilla. 
las esguevas de la ciudad burgalesa. ${ }^{20}$ La malaria, las «quartanas» $\mathrm{y}$ «tercianas», será el mal del siglo en la Castilla del Setecientos. ${ }^{21}$

El siglo XVIII presenta, desde la óptica de la petición, la primera concesión y las prórrogas del PQ, 5 etapas bien caracterizadas, cada una con un perfil definitorio y unas vicisitudes que las singularizan de las demás. El contraste resulta evidente en múltiples sentidos.

Un primer tramo, 1700-1734, se caracteriza por el predominio abrumador de la patología que daba nombre al «Punctto» -gráfico III-. El 67.9\% de las afec-

${ }^{20}$ Sobre las esguevas de Burgos Carmona Urán, G. 1954. Historia de las viejas rúas burguenses: 15-16 y 125, Burgos y Iglesias Rouco, L. S. 1978. Arquitectura y urbanismo de Burgos bajo el reformismo ilustrado (1747-1813): 30 y 45, Burgos.

${ }^{21}$ Véanse Pérez Moreda, V. 1982. «El paludismo en España a fines del siglo XVIII: la epidemia de 1786». Asclepio 34: 295-316, 1980. Las crisis de mortalidad en la España interior. Siglos XVI-XIX: 74-76 y 336-350, Madrid y Pérez Moreda, V. 1984. «Crisis demográficas y crisis agrarias: paludismo y agricultura en España a fines del siglo XVIII», en Congreso de Historia Rural. Siglos XV al XIX: 333354, Madrid, Sánchez Granjel, J. L. 1979... 106 y 693-704, Díaz Pintado, J. 1991.«Epidemias de paludismo en La Mancha del XVIII». Cuadernos de Historia Moderna 12: 123-166, Peset Reig, M. y J. L. 1979. «Tercianas y ciencia médica en el Setecientos valenciano», en I Congreso de historia del País Valenciano: vol. III, 685-694, Valencia y Peset Reig, M. 1972. «Cultivos de arroz y paludismo en la Valencia del siglo XVIII». Hispania 121: 277-375 y 1978. «Epidemias y sociedad en la España del fin del Antiguo Régimen». Estudios de Historia Social 4: 16-19, Mateu Tortosa, E. 1987. Arroz y paludismo. Riqueza y conflictos en la sociedad valenciana del siglo XVIII, Valencia, Capel Sáez, H. 19981999. «Medicina y clima en la España del siglo XVIII». Revista de Geografía 32-33: 89-98, Riero Palmero, J. 1984. Fiebres y paludismo en la España ilustrada: Félix Ibáñez y la epidemia de La Alcarria, 1784-1792, Valladolid, Alberola Romá, A. y Bernabé Gil, D. 1998-1999. «Tercianas y calenturas en tierras meridionales valencianas: una aproximación a la realidad médica y social del siglo XVIII». Revista de Historia Moderna 17: 95-112, Alberola Romá, A. 1985. «Una enfermedad de carácter epidémico en el Alicante del XVIII: las fiebres tercianas». Revista de Historia Moderna 5: 127-140 y Alberola Romá, A. 1985. «Fiebres, ciencia médica y política sanitaria en el Alicante del Setecientos». Canelobre 4: 85-89, Bernabé Gil, D. 1985.«Tercianas y prevención pública en el Siglo de las Luces: el caso del Bajo Segura». Canelobre 4: 77-83, Pérez Medina, T. V. 1991. "Arròs, paludisme i població a la comarca de l'Horta. L'epidèmia de 1784». Afers 11-12: 137-150, Pons i Sierra, L. 2001. «L'epidèmia de terçanes de l'any 1785 a Agramunt». URTX, Revista cultural de l'Urgell 14: 205-215, Rosado Batea, I. y Vidal Casero, M. C. 1985.«Paludismo en el siglo XVIII: graves epidemias de tercianas afectaron al este español en los años 1784 y 1785», en IV Congrés d'Història de la Medicina Catalana: vol. I, 325-332, Poblet, Zarzoso i Orellana, A. 1998.1999. «iObligación moral o responsabilidad política? Las autoridades borbónicas en tiempo de epidemias en la Cataluña del siglo XVIII». Revista de Historia Moderna 17: 73-94, Sobrevía Clavera, A. 2004.«El cultivo del arroz de secano en Cataluña (1778-1839). Una propuesta agronómica al problema del paludismo». Asclepio 56: 169-196, Sáez Gómez, J. M. y Marset Campos. 2000. «Teoría académica y práctica ciudadana en el paludismo. Las causas de las enfermedades endémicas en Murcia durante el siglo XVIII desde la perspectiva de la administración local». Asclepio 52: 167-183 y Frías Núñez, M. 2003.«El discurso médico a propósito de las fiebres y de la quina en el Tratado de las calenturas (1751) de Andrés Piquer». Asclepio 55: 215233. Hay más, como veremos posteriormente. Véanse también las sabrosas y nutritivas reflexiones de Fagan, B. 2009. La pequeña edad de hielo. Cómo el clima afectó a la historia de Europa, 1300-1850: 207-219, Barcelona.

Hispania Sacra, LXIV

130, julio-diciembre 2012, 661-719, ISSN: 0018-215X, doi: 10.3989/hs.2012.020 
GRÁFICOI.

PUNTO DE QUARTANARIO EN LA CATEDRAL DE BURGOS

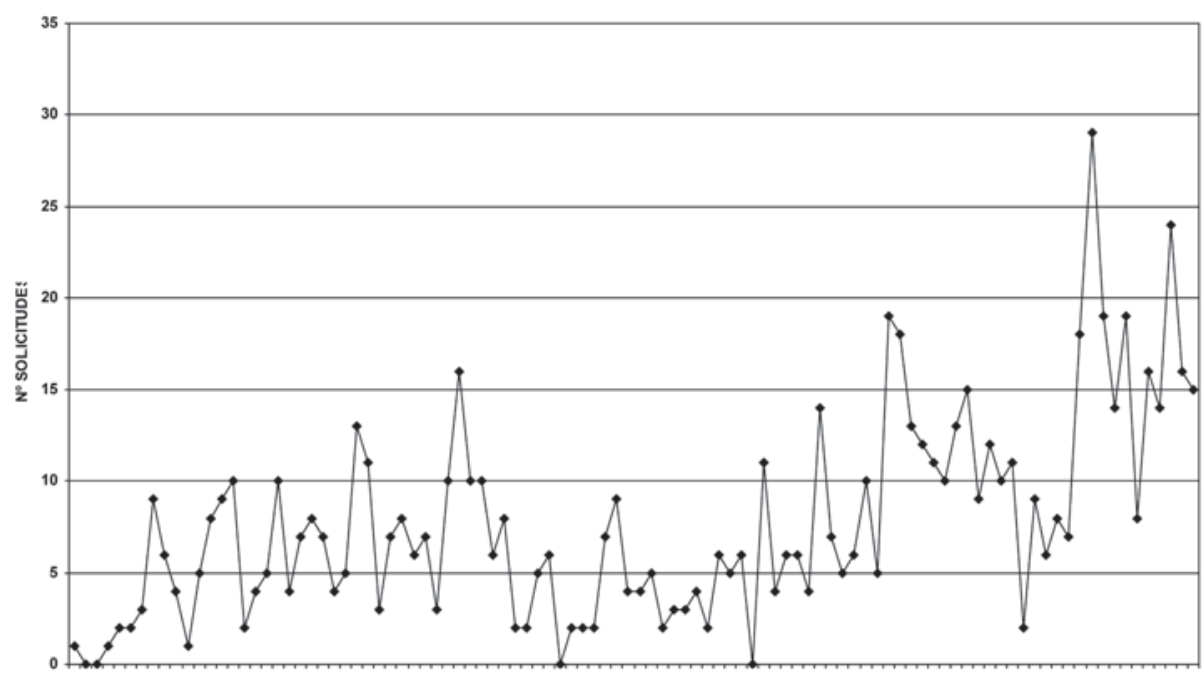

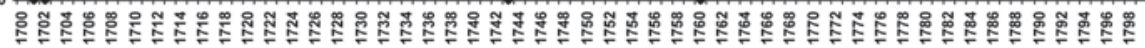

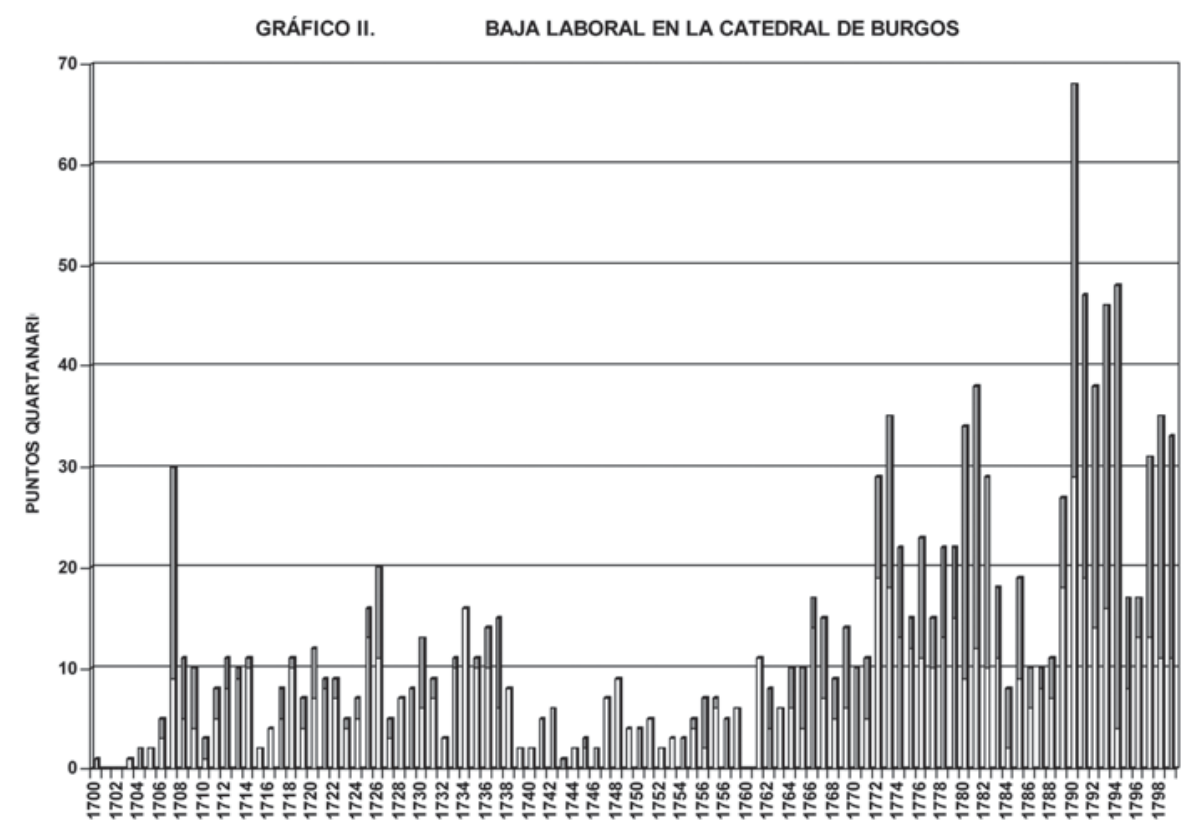

$\square 1$ BAJA $\square$ PRORROGA 
ciones del período inicial del siglo se debieron a las «quartanas», mientras que las «tercianas» ocasionaron el $9.1 \%$ de las solicitudes, las afecciones reumáticas y artríticas y la gota son el $1.5 \%$, respectivamente, y a otras enfermedades, como, por ejemplo, la perlesía, la demencia ${ }^{22}$ o la alferecía, se debieron el $21.6 \%$ de los memoriales suplicatorios de los prebendados catedralicios..$^{23}$

\section{GRÁFICO III ENFERMEDADES EN EL CABILDO CATEDRAL (SIGLO XVIII)}

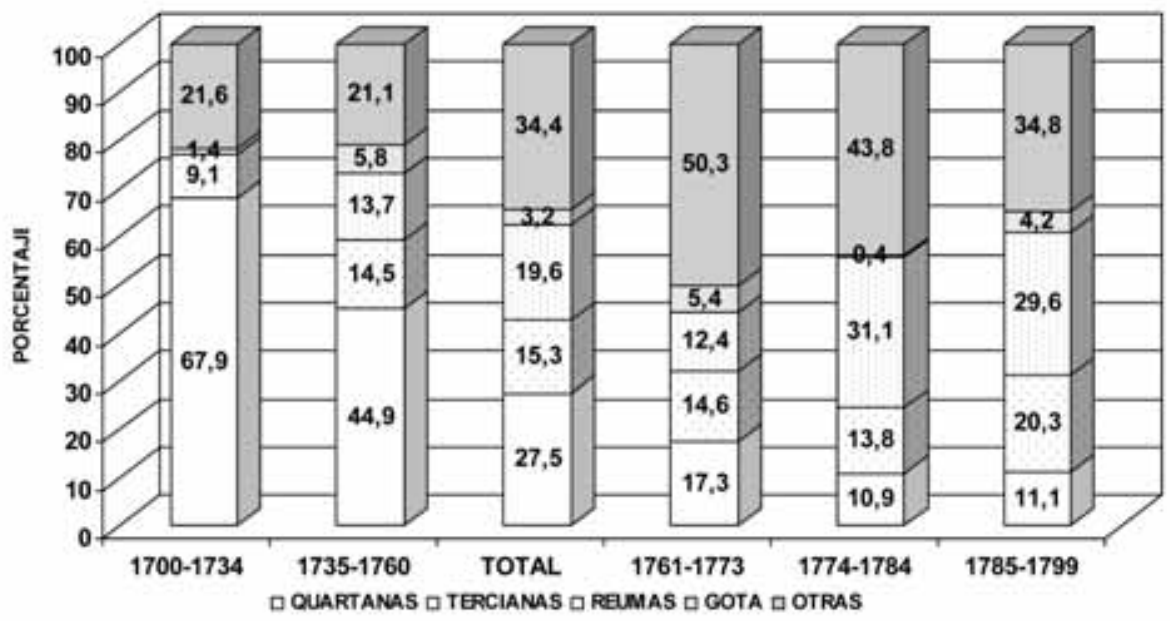

El promedio anual de peticiones fue escaso, con 5.74 solicitudes de «Punctto de Quartanario» por año -gráfico IV-, si bien hay un progresivo incremento, realmente substancial y a veces vertiginoso, entre las nulas ocurrencias de $1702-1703$ y 16 de 1734 -gráfico I-.

Esta etapa muestra un perfil cambiante, aunque con una evidente tendencia ascendente -gráfico I- en el que alternaron momentos de máximo y mínimo. Fueron momentos de «valle» 1700-1705, 1710, 1715-1716, 1719, 1727 y 1732. Por el contrario, la solicitud de PQ se disparó en 1707, 1711-1714, 1720-1721, 1725-1726 y 1733-1734. Si se incluyen las prórrogas hay un momento especialmente álgido, en 1707, con 21 prórrogas, 14 por réplica de las «quartanas»-. La adversa climatología está en la base de las afecciones.

${ }^{22}$ López Gómez, J. M. 1998. «La enfermedad del canónigo Calderón. Una historia clínica de demencia en el Burgos de principios del siglo XVIII». Revista de la Asociación Española de Neuropsiquiatría 66: 307-321 y Sanz de la Higuera, F. J. 2009... 41-68.

23 También aparecen diarreas, ciáticas, cólicos nefríticos, etc., aunque en menor medida. Véase Peter, J. P. 1972. «Malades et maladies à la fin du XVIII ${ }^{\mathrm{e}}$ siècle», en Le Roy Ladurie, E., Desaive, J. P. y otros, Médecins, climat et epidémies à la fin du XVIII siècle: 135-170, París. 


\section{GRÁFICO IV PUNTO DE QUARTANARIO: CATEDRAL DE BURGOS}

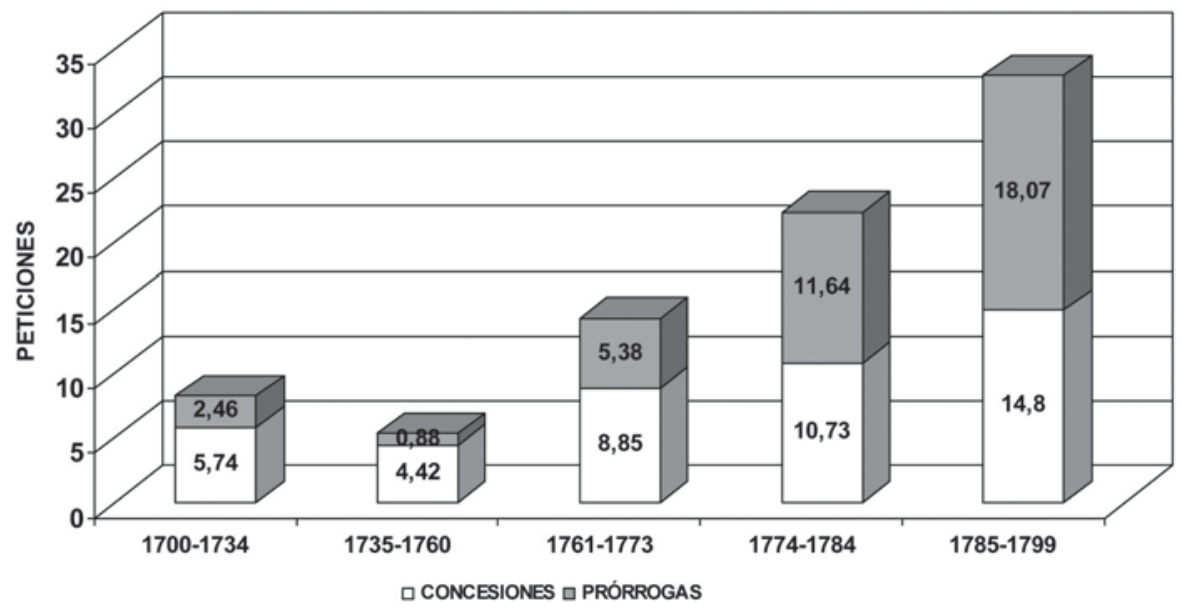

El recorrido de los gráficos I y II es similar al obtenido para la mortalidad de la ciudad en su conjunto - gráfico V-. El decenio inicial, con la Guerra de Sucesión, conoció, además de un pavoroso número de afectados por el conflicto, un notable empeoramiento climático. El Cabildo ordinario del 21 de abril de 1703, que refrendaba las decisiones del 14 de diciembre de 1699 y el 22 de noviembre de 1700 , señaló que se negaría todo punto de quartanario «excepto en propia enfermedad de quartana».

Esto explica, en parte, los datos señalados antes. ${ }^{24}$ Es probable una autocensura en los comportamientos clínicos de los prebendados. En noviembre de 1700 le fue denegada la «baja» a un canónigo y se advirtió que sólo se concedería «en caso que se padezca Verdadera y propiamente la enfermedad de quarta$n a »$. La certificación del médico no contenía el diagnóstico pormenorizado de la enfermedad, que será imprescindible más adelante. La votación fue categórica: 17 blancas y 1 negra. ${ }^{25}$

El Cabildo será muy riguroso en la aplicación de lo dispuesto. El debate entre los capitulares giraba alrededor de la conveniencia o no de moderar las concesiones. La decisión pasaba necesariamente por el examen de cada expediente.

${ }^{24}$ ACC. AC. LR 93. Cabildo del 21 de abril de 1703, folio 275 y LR 113, Cabildo del 6 de junio de 1776, folios 655-656. En 1776, las indagaciones de los Archivistas nos descubren que el PQ se instituyó en 1576 -LR 58, folio 150- y que, con el paso del tiempo, «haviéndose experimentado algunos abusos por su extensión, se tomó Providencia en el año de 1694, negándose a todos generalmente».

25 ACC. AC. LR 92, Cabildo del 22 de noviembre de 1700, folio 212. 
En abril de 1704 se retomó la polémica y se trajeron a colación, de nuevo, los «puntos de derecho y theología moral cerca de dar el punctto a los Sres Prevendados que Realmente lo necesitan para Convalecer y adquirir la salud de sus enfermedades», circunstancias que pasaban inexorablemente por hacer ejercicio «y si este no bastase, mudar de Región», porque si «se tenía riesgo de su vida no haciendo así se exponía a la repetición de los accidentes peligrosos que avía padecido». ${ }^{26}$

El temor a los fraudes estimulaba y extremaba los controles. En el auto capitular del 14 de diciembre de 1699, como referencia ineludible, «se confirió [se] sería mui riguroso [en] lo dispuesto por dhos Autos capitulares». El asunto esencial «abla Cerca del Puncto de Quartanario de los que piden sin padecer la enfermedad propia de la Quartana».27 Los archivistas, a requerimiento del pleno capitular, escudriñaron el «histórico» del Cabildo y se esgrimieron, escrutadas las Actas, los debates y decisiones del 5 de octubre y del 30 de noviembre de 1576, «sobre el modo en que havían de tener los Prevendados el Punctto de Quartanario». La existencia de fraudes y los abusos descubiertos extremaron las precauciones y ello generó denegaciones.

La pauta del período la hallamos en la enfermedad sufrida por el canónigo Igay, quien en noviembre de 1706 consiguió el PQ «por término de dos meses con las circunstanzias y limitaciones que tiene dispuesto el Cavildo por sus Autos capitulares». Se recurrió a 7 prórrogas de un mes entre el 20 de diciembre de 1706 y el 29 de diciembre de 1707.28 El proceso de la patología hizo que el doctoral reiterara mensualmente la continuidad en la «baja laboral» porque «no se hallaba libre de sus quartanas». ${ }^{29}$ La concesión al canónigo Guerra, en septiembre de 1708, denunció la existencia de prácticas irregulares. Se aprobó que «era escrupuloso que los Sres que continuamente no ganaban Vísperas y las horas menores estando sanos y desocupados las ganasen con el punto de quartanario» y se acordó «que al presente se lo diese a entender a dhos Sres para que en ello obrasen lo que pareciesse conforme a su Conciencia». ${ }^{30}$ No todos lo percibían de la misma forma.

Las peticiones de PQ a lo largo de esta primera etapa revela un inicial cicaterismo en la concesión de la «baja laboral», pero esta rigidez se fue relajando ante la presión de circunstancias históricas y climáticas. Se añadieron nuevos

${ }^{26}$ ACC. AC. LR 93, Cabildo del 21 de abril de 1704, folio 275.

27 ACC. AC. LR 93, Cabildo del 23 de abril de 1703, folio 64. Los referentes más cercanos serán siempre las resoluciones del 14 de diciembre de 1699 y el 22 de noviembre de 1700 .

28 ACC. AC. LR 94, Cabildo el 5 de noviembre de 1706, folio 130 (primera concesión), Cabildo del 20 de diciembre de 1706, folio 145 (primera prórroga por un mes) y Cabildo del 29 de diciembre de 1707, folio 319 (última prórroga).

${ }^{29}$ ACC. AC. LR 94, Cabildo del 15 de noviembre de 1706, folio 134.

${ }^{30}$ ACC. AC. LR 94, Cabildo del 17 de septiembre de 1708, folio 439. 
motivos para poder pedir y obtener la «baja». No será únicamente la «calentura» palúdica, fuera ésta «quartana» o «terciana», etiologías «Quartanarias» predominantes y casi exclusivas. Se fueron contemplando otras disfunciones como las que afectaban a ojos, garganta, pecho, piernas, riñones, huesos... Se tendrían en cuenta en las votaciones del Cabildo.

La institución se abría a las problemáticas de sus miembros. La solidaridad con los padecimientos de cualquier tipo, se hizo extensiva a las necesidades clínicas más perentorias. Esto no significa, el abandono de las cautelas ni de la búsqueda de seguridades ante el fraude. ${ }^{31}$ Así, el canónigo Escalante, que pidió varias prórrogas, «en attenzión a hallarse sin mejoría en su indisposición y que para Combalecer nezesitaba salir de esta Ciudad a tomar los ayres», se vio sorprendido en marzo de 1709 con la denegación del punto de quartanario porque «abiendose tenido presente el largo tiempo que avía gozado deel y que no havia exercicio para cuyo efecto se le concedió, se acordó debérsele denegar y denegó».32 $\mathrm{Al}$ canónigo Castañeda, en agosto de 1721, «no se le dio por haver insinuado al Cavildo no le necesitaba por quanto se hallaba enteramente convalezido». En ese mismo momento, al canónigo Madrazo se le concede la «baja laboral» por un mes, aquejado de tercianas. ${ }^{33}$

La solidaridad tenía un aspecto egoísta, cuando las patologías, certificadas por los médicos, eran contagiosas. Eso sucedió con Escalante, quien, en junio de 1710, fue diagnosticado de «hecticia y tísica», mal sobre el que era conveniente «precaber su Concurrenzia por lo Contajioso de dha enfermedad».34

Los ánimos estaban bastante caldeados en el Cabildo. En septiembre de 1722 , un canónigo denunciaba «el abuso que avia en dhos punctos» ${ }^{35}$ y exigía

\footnotetext{
${ }^{31}$ Capitulares y Cabildos enfrentados a «compadres» catedralicios manifiestamente deshonestos y problemáticos han sido descritos, entre otros, en los trabajos de Quintana Andrés, P. C. 2003: 102, 119-121 y 123, Canovas Botía, A. 1997: 309-311, Morgado García, A. 1989: 100-102 y García-Cuevas Ventura, J. 1996: 34.

32 ACC. AC. LR 94, Cabildo del 19 de noviembre de 1708, folio 481 (primera concesión) y Cabildo del 22 de marzo de 1709, folio 549 (denegación de prórroga). Uno de sus «compadres», el canónigo Tomás de Salazar, alzó enérgicamente su voz ante el Cabildo para denunciar tan tremenda falta de humanidad, dado que Escalante «se hallaba Cada días más fatigado de su indisposición», de la que podrían resultan funestas consecuencias. ACC. AC. LR 94, Cabildo del 10 de mayo de 1709, folio 571.

${ }^{33}$ ACC. AC. LR 98, Cabildo del 8 de agosto de 1721, folio 255 (petición del PQ por «Erisipela») y Cabildo del 11 de agosto de 1721, folio 258 (denegación). El PQ de Madrazo en Cabildo de 8 de agosto de 1721 , folio 255 .

${ }_{34}$ ACC. AC. LR 95, Cabildo del 20 de junio de 1710, folio 169. Lo alarmante y peligroso de esas patologías impelió al Cabildo a recavar certificaciones de 3 médicos, a quienes se exigió «vissitasen y reconoziessen la enfermedad que padezía, su Calidad y (...) si era Curable o incurable y qué medicinas y medios eran Convenientes siendo Curable, y si sería conveniente Salir de esta Ciudad a tomar los ayres de su Patria o de otra parte».

${ }^{35}$ ACC. AC. LR 98, Cabildo del 25 de septiembre de 1722, folio 466. En el Cabildo del 19 de octubre de 1722, «se trató de arreglar el modo y circunstancias con que se deben conceder los puntos de
} 
una reforma que el Cabildo debía poner en marcha con rapidez. «Se trató y confirió largamente y aviendose leydo el estatuto que trata y define esta materia, que es la Constituzión 37 folio 51 per totum, y algunos autos Capitulares, en su razón se acordó que, para mayor inteligencia y explicazión, los Sres Penitenciario y Haedo formen un papel exponiendo con toda claridad el modo y circunstancias con que se deberá usar de dho puncto y apunctar al que se le concediese según lo que por dha consulta y estatuto se previene». ${ }^{36}$

Prueba del desasosiego e inquietud reinante fue el asunto suscitado en octubre de dicho año (1722). «En el Cavildo se trató de arreglar el modo y circunstancia con que se deve conceder los punctos de Quartanario para evitar los abusos que se experimentan según repetidas veces se halla presentado por algunos Sres y haviendo precedido el informe y dictamen de los Sres de ofizio y dn Gaspar de Haedo, que sobre este asumpto se expresaron, se acordó que en la concesión de dhos Puncttos de Quartanario se observe en adelante lo siguiente: Que quando algún Sr Prevendado le pida u otro qualquiera de los que en Cavildo acostumbran solicitar esta grazia, aian de presentar certificación deel Médico, que pide la necesidad no sólo en quanto a salir de Casa por motibo de hacer egercicio el que ha estado enfermo sino también que la residencia de la Iglesia le pueda ser dañosa a la salud y retardar la convalescencia, expresando el tiempo que prudencialmente necesitará para lograrla».37

Ejemplo de prebendados con graves problema de «quartanas» es el medio racionero Manuel González, aquejado de doble quartanas en febrero de 1723. Se vio obligado a solicitar prórroga «en atención a proseguirle con maior rigor sus quartanas». ${ }^{38} \mathrm{Al}$ canónigo Tomás de Salazar se le concedieron 2 meses en noviembre de 1708 para remedio de sus «quartanas». 39

Las «tercianas» traían por la calle de la amargura al arcediano de Valpuesta, Garma de la Puente, quien, en septiembre de 1720, «en attención a hallarse

\footnotetext{
Quartanario para evitar los abusos que se experimentan, según repetidas veces se halla presentado por algunos Señores», prueba evidente de las múltiples denuncias que se detectaban en la petición, concesión y prórrogas de la «baja laboral». Cabildo del 19 de octubre de 1722, folios 495-496.

${ }^{36}$ ACC. AC. LR 98, Cabildo del 25 de septiembre de 1722, folio 466.

${ }^{37}$ ACC. AC. LR 98, Cabildo del 19 de octubre de 1722, folios 495-496. Véase, también, ACC. AC. LR 113, Cabildo del 8 de junio de 1776, folios 655-656. A partir de ese momento, y en el seno de los expedientes para la concesión del PQ perpetuo a los canónigos Carrera y Haedo, pasó a ser conditio sine qua non para la concesión del PQ la presentación de la «Certificación jurada del Médico, con expresión deel tiempo que prudencialmente necesite el enfermo para la Combalescencia que es conveniente para ésta, el exercicio fuera de Casa y perjudicial la residencia en el Coro. De suerte que por la Certificación pueda arreglarse el tiempo que se le ha ya de conceder».

${ }_{38}$ ACC. AC. LR 98, Cabildo del 18 de febrero de 1723, folio 542. En octubre del año anterior ya había padecido de la misma enfermedad -Cabildo del 2 de octubre de 1722, folio 471-y en marzo de 1723 aún perseveraba en ellas «en atención a proseguirle con maior rigor sus quartanas». Cabildo del 15 de marzo de 1723 , folio 533 -.

${ }^{39}$ ACC. AC. LR 94, Cabildo del 16 de noviembre de 1708, folio 478.
}

Hispania Sacra, LXIV

130, julio-diciembre 2012, 661-719, ISSN: 0018-215X, doi: 10.3989/hs.2012.020 
convaleciente de una perniciosas tercianas que avía padezido y que le havían ocasionado algunos humores, por cuia expulsión necesitaba algún exercicio», rabiaba ante el Cabildo para conseguir el PQ. ${ }^{40}$ No menos ansioso estaba, en julio de 1726, el canónigo Díaz Cosío, «en attenzión a la devilidad y falta de fuerza con que se halla, motivado de unas terzianas vastantemente penosas que ha padezido». ${ }^{41}$ El canónigo Díaz de la Peña estaba igualmente, en diciembre de 1729, muy sensibilizado, pues «haviendo padezido el penoso accidente de tercianas, y por este motivo haversele hecho alguna evacuazión, se halla sumamente debilitado y teme que la gran frialdad de la Iglesia le sirba de perjuicio a su recobro». ${ }^{42} \mathrm{El}$ lectoral Prieto Bustamante ${ }^{43}$ «hacía muchos días [en agosto de 1733] padezía unos vehementes dolores de caveza a que se le siguieron unas perniciosas terzianas». ${ }^{44}$

Dolorosas complicaciones reumáticas tuvo el canónigo Gaspar de Haedo. Solicitó la «baja» en diciembre de 1721 porque «ha padezido un afecto Reomático» que le había dejado exhausto. ${ }^{45}$ El canónigo Madrazo, «hallándose [en enero de 1709] Cada día más penoso del afecto de piedra», solicitó también el PQ dado que los facultativos «le aconsejaban para su remedio fuese a beber del agua del Pozo de Gayangos». ${ }^{46}$

En mayo de 1720, el canónigo Marañón, que «se halla con grave achaque y Specialmente con detenzión de Orina que no le permite la residencia sin grave

${ }^{40}$ ACC. AC. LR 98, Cabildo del 27 de septiembre de 1720, folio 89.

${ }^{41}$ ACC. AC. LR 100, Cabildo del 19 de julio de 1726, folio 80.

${ }^{42}$ ACC. AC. LR 101, Cabildo del 23 de diciembre de 1729, folio 32. Sobre las frialdades de las Catedrales y las enfermedades de los capitulares, véase Cabeza Rodríguez, A. 1997.La vida en una Catedral del Antiguo Régimen: 34-40, Palencia.

${ }^{43}$ Sobre este capitular véanse Sanz de la Higuera, F. J. 2009. «La librería del canónigo lectoral Prieto Bustamante. Libros y mesas de trucos a la greña. Burgos (1749-1766)», en Álvarez Santaló, L. C. (Coord.), Estudios de Historia Moderna en homenaje al profesor Antonio García-Baquero: 639-659, Sevilla y Sanz de la Higuera, F. J. 2006. «Seminario de San Nicolás (Burgos, 1743): una rectoría apetecible, un litigio aborrecible». BIFG 232: 149-177.

${ }^{44}$ ACC. AC. LR 102, Cabildo del 31 de agosto de 1733, folio 282. «... aconsejándole el médico que le ha asistido que para su convalecencia le sería conveniente pasar a tomar los aires naturales [de su tierra natal, Santander] y que el temperamento de esta Ciudad y frialdad de la Iglesia le era contraria».

${ }^{45}$ ACC. AC. LR 98, Cabildo del 12 de diciembre de 1721, folio 326.

${ }^{46}$ ACC. LR. LR 94, Cabildo del 7 de enero de 1709, folio 505. El PQ se le concedió por 2 meses. En abril de 1709 se le permitió la prórroga, dado que «está tomando el agua de los Pozos de Gayangos para su Curación y necesita de él para proseguirle». Sobre dichos tratamientos termales véase Gutiérrez Rodilla, B. M. 1999. «Sobre la hidrología médica en la España barroca». Medicina e Historia 3: 1-16, Caro Puértolas, 2003. «Pasado y presente de los Balnearios en Extremadura». Revista de Estudios Extremeños 59/1: 319-341, Bau, A. M. y Canavese, G. F. 2006. «Agua que cura, agua que alimenta». La dietética para sanos y el agua en la sociedad española bajomedieval y moderna». Cuadernos de Historia de España 80: 127-146, Rodríguez Sánchez, J. A. 2007. «Agua que aún mueve molino: aproximación a la historia balnearia». Anales de Hidrología Médica 2: 9-26, Rosa Jorge, M. C. y Mosso 
perjuicio de su Salud». ${ }^{47}$ El maestre escuela de entonces pidió la «baja» como consecuencia de un «Accidente de la Gota que ha padezido [y porque] le es summamentte perjudicial la rresidenzia de la Mesa y su frialdad en el riguroso tiempo presente [enero de 1726] por lo que le aconsejaban los Médicos se abstenga della por algunos días».48

En abril de 1734, al medio racionero y músico Diego de la Peña, «haviéndole repetido el accidente de flujo de sangre por la voca, le aconssejaban los $\mathrm{Zi}$ rujanos y Médicos pasase a tomar los ayres naturales de la tierra». ${ }^{49}$ En mayo (1734), todas las habas fueron blancas, dada la «presente notoria nezesidad del suplicante». 50

Del canónigo Miguel González, en octubre de 1731, decían los médicos «haver padezido, y estar actualmente padeziendo, una fluxión tan vehemente en los ojos que le impide aún salir de casa y por consiguiente la residenzia en la Iglesia, siendo preziso tratar de hacer algunos remedios para su curazión, perjudicándole a ella la intemperie de la Iglesia». ${ }^{51}$ De semejante tenor era la «gran turbazión de vista y debilidad que le imposibilitaba la residencia en el choro, como lo acredita la certificación del Médico» de que estaba aquejado el racionero José de Castrosana, quien obtuvo la «baja laboral» de «un mes para dentro de la Ciudad y dos meses para fuera» con todas las habas blancas..$^{52}$

En octubre de 1726, se había suscitado otra de las facetas espinosas del patitur, ante la polémica que el deán Rubín generó sobre el intrincado asunto del desde cuándo corre la «baja laboral». El Cabildo decidió que «no empieza cuando quiera el prebendado sino a partir del día del Decreto y no desde el día en que lo use por lo que le pareciere a dho Señor».53

Romeo, M. A. 2004. «Historia de las aguas mineromedicinales en España». Observatorio Medioambiental 7: 117-137, Pérez Fernández, M. R. y Novoa Castro, B. 2002. «Historia del agua como agente terapéutico». Fisioterapia 24: 3-13, Gutiérrez-Cortines Corral, C. 1990. «La arquitectura del Agua: Los Balnearios del Mar Menor». Imafronte 6-7: 79-92 y Silva Prada, N. 2002. «El uso de los baños temascales en la visión de dos médicos novohispanos. Estudio introductorio y transcripción documental de los informes de 1689». Historia Mexicana 52/2: 5-56,

${ }^{47}$ ACC. LR 98, Cabildo del 10 de mayo de 1720, folio 29. Véase también las patologías del capiscol Juan de Salazar, aquejado de «grave accidente de supresión de Orina». ACC. AC. LR 98, Cabildo del 9 de junio de 1721, folio 219.

48 ACC. AC. LR 100, Cabildo del 7 de enero de 1726, folio 12.

49 ACC. AC. LR 102, Cabildo del 15 de abril de 1734, folio 501.

50 ACC. AC. LR 100, Cabildo del 17 de mayo de 1734, folio 532.

${ }^{51}$ ACC. AC. LR 101, Cabildo del 26 de octubre de 1731, folio 401. Véase Sanz de la Higuera, F. J. 2012. «Aproximación a los problemas en la visión y el uso de anteojos en el Burgos de mediados del siglo XVIII», El Futuro del Pasado 3: 371-401.

52 ACC. AC. LR 102, Cabildo del 5 de septiembre de 1732, folio 16.

${ }^{53}$ ACC. AC. LR 100, Cabildo del 20 de diciembre de 1726, folio 147. 
La inflación de patologías enervaba los ánimos y acaloraba los debates en el seno del Cabildo. En septiembre de 1733 se aplicó un Decreto del 4 de junio de 1731 según el cual «el maestro de capilla puede y debe gozar del punctto de Quartanario en la misma conformidad que todos los demás Sres Prebendados sin diferencia alguna». ${ }^{54} \mathrm{El}$ citado maestro de capilla, don Francisco Hernández Yllana, «havía padecido una peligrosa enfermedad la que lo había debilitado tanto las fuerzas que se halla con imposibilidad de asistir en todo este mes de septiembre a su ministerio, en cuia attenzión y a serle perjudicial para su recobro la asistenzia a la Iglesia» hubo de batallar para lograr la «baja laboral» que, por derecho, le pertenecía. 55

El canónigo Verde Sañudo no colaboró mucho en el afán de edulcorar el ambiente -secuelas de «hallarse relaxado de una Cadera»-. Los sucesivos memoriales llegados al Cabildo en julio de 1714 solicitaban «salir diez y ocho leguas de esta Ciudad a la curazión de un golpe que dho Sr recivió en una Cadera».56 Tras un viaje, a resultas «del qual se hallaba postrado en Cama»,57 puso a sus compadres en dificultades, como era habitual en su proceder. ${ }^{58}$

En la etapa 1735-1760 -gráficos I, II, III y IV- se produjo un descenso significativo en la intensidad de las peticiones de PQ y de sus prórrogas, pasándose desde las 10 solicitudes de 1735 hasta la más absoluta carencia de indisposiciones de 1743 y un período posterior de actividad escasa, con excepción de breves y fugaces años de cierta intensificación (1747-1748), relacionados con crisis climáticas, productivas y bélicas.

${ }^{54}$ ACC. AC. LR0 102, Cabildo del 25 de septiembre de 1733, folio 310.

55 ACC. AC. LR 102, Cabildo del 7 de septiembre de 1733, folio 293. De hecho en la votación las habas fueron todas blancas. Del asunto se desprende que existieron notorias discrepancias previamente, quizá por el carácter unipersonal, singular e intransferible de su cargo. Hernández Yllana dio muchos problemas al Cabildo y sufrió en sus carnes múltiples patologías. Sobre conflictos similares véase Gómez Pintor, M.A. 1997. «Acciones jurídicas en un cabildo catedralicio: los racioneros en defensa de su posición social frente al maestro de capilla». Anuario musical: Revista de musicología del CSIC 52: 77-100.

56 ACC. AC. LR 96, Cabildo del 24 de julio de 1714, folio 344.

57 Sobre lechos y camas en el siglo XVIII, y sus utilidades y servidumbres, Sanz de la Higuera, F. J. 2009. «Pajas, catres, cujas, camas,... El lecho cotidiano en el Antiguo Régimen. Burgos (17401780)». Cuadernos de Investigaciones Históricas 26: 435-499.

${ }^{58}$ Se encuentra en proceso de evaluación un trabajo, que pretendo aparezca en su momento publicado en Historia y Genealogía, si así lo decide su Consejo de Redacción, titulado «¿Qué había debajo del «solideo con orejeras» del canónigo Verde Sañudo? (Burgos, 1707-1718)», Córdoba. En él se evalúan las problemáticas profesionales y humanas de un prebendado polémico, padre de, al menos, 4 hijos, estudioso furibundo y encarnizado polemista y crispado «compadre» de los demás canónigos del Cabildo catedralicio, con algunos de los cuales llegó a la agresión física y el insulto más escandaloso. Sus patologías clínicas, sus salidas de tono y su paso por las cárceles de la Catedral perfilan un carácter colérico y problemático que se empeñó en quebrar casi todas las normas de conducta más elementales y esenciales en sus relaciones humanas y profesionales. 
El promedio de solicitudes y prórrogas del período, 4.42 y 0.88 , delatan, por contraste con las etapas anterior (1700-1734) y posterior (1761 en adelante) el cambio de tendencia y, en último extremo, la mejora climática y económica. De nuevo, la concordancia con la mortalidad general de la ciudad es, salvo ligeras excepciones, nítida - gráfico $\mathrm{V}$-.

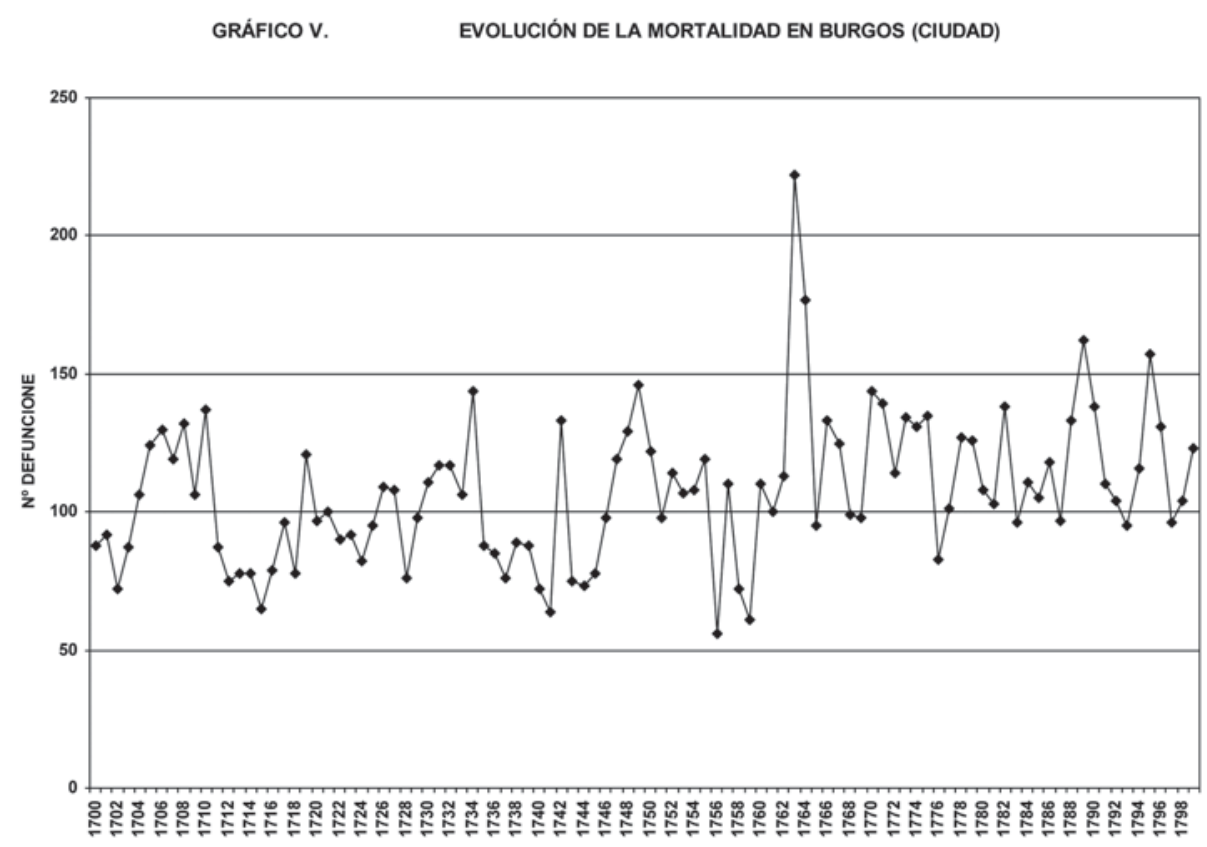

El peso relativo de las patologías que aquejaban a los capitulares se transformó substancialmente. El descenso de las «quartanas», desde el 67.9 al 44.9\%, quedó compensado con el incremento en el volumen de «tercianas», que alcanzaron el $14.5 \%$, las afecciones reumáticas y artríticas (13.7\%) y las derivadas de la gota y su manifestación más traumática, la podagra -que pasan desde el raquítico $1.4 \%$ del momento anterior hasta un substancioso $5.8 \%$ de este período-. Las «otras» enfermedades apenas experimentan modificación -gráfico III-.

El siglo del paludismo comenzaba a reflejarse en las patologías de los componentes del Cabildo catedralicio burgalés. Las «otras» enfermedades -perlesías, erisipelas, tabardillos, afecciones oculares, diarreas, reumas, tumores, etcétera-, inducen a pensar, igualmente, en un lento pero progresivo e imparable proceso de relajación y en una diversificación paulatina de los motivos para la «baja laboral». 
Aunque 1735-1760 es una etapa bisagra, de descenso en las enfermedades entre los miembros del Cabildo, las patologías sufridas no fueron menos perturbadoras. El maestro de capilla y canónigo Hernández Yllana, en enero de 1735, «se hallaba con el accidente de Quartanas que le davan con vastante Rigor»,59 El médico tenía por preciso y conveniente para su recobro el que hiciese ejercicio y se retirase de la residencia del coro.

El frío en la Catedral era, como se atestigua a través de las certificaciones de los profesionales de la salud, y en especial, de las reflexiones del médico titular del Cabildo, uno de los ingredientes esenciales en la etiología de los trastornos de los capitulares. El consumo de combustibles, en especial de carbón, va a crecer, durante el Setecientos, a un ritmo similar al del PQ -gráfico VI-. La climatología y las necesidades de los capitulares obligaban a un mayor desembolso económico a un mejor ajuste de las «bajas laborales». Paliar la destemplanza en la Catedral suponía adquirir más carbón. ${ }^{60}$

GRÁFICO VI. CONSUMO DE CARBÓN (CATEDRAL)

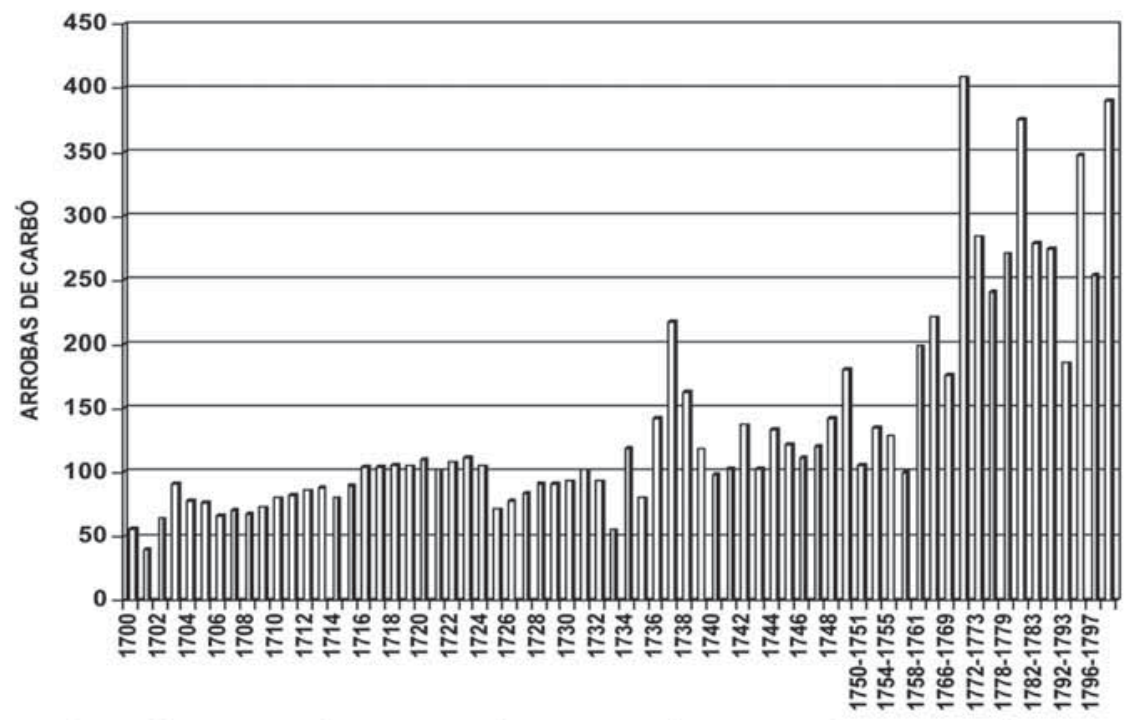

${ }^{59}$ ACC. AC. LR 102, Cabildo del 7 de enero de 1735, folio 680.

${ }^{60}$ Un estudio sobre el consumo de carbón vegetal y leña en la ciudad de Burgos durante el siglo XVIII verá la luz en breve. El volumen de gasto de tales combustibles es un poderoso «barómetro «del devenir climático, aspecto en el que hasta ahora se ha considerado como esenciales el tratamiento de la evolución de los cereales y del viñedo. Los combustibles vegetales del Antiguo Régimen aparecen, a mi entender, como una de las «cenicientas» de la reconstrucción del abastecimiento y del consumo del acontecer humano y económico. 
Las ocurrencias fueron múltiples y los ejemplos son curiosos. Descuellan las afecciones sufridas por el canónigo Manuel Calleja, quien, en mayo de 1736, «avía siete meses estaba padeciendo un tumor excirroso en el Vazo, el que junto con algunas Calenturas que le han sobrevenido le tenían summamente debilitado y siéndole notoriamente perjudicial la residencia de la Iglesia para su curazión y mui conduzente al exerçicio». Los médicos señalaban se tomara un mes ó dos de «baja».61

Un canónigo agradable, cumplidor y afectuoso como Calleja no suscitaba la animadversión de nadie. El Cabildo apoyó las recomendaciones médicas y las habas fueron todas blancas. El canónigo Manuel del Regato, «haviendo padeçido diberssos achaques y accidentes y experimentado en ellos algún alibio, neçesitaba para su perfecto recobro retirarse de la Residençia de la Iglesia y haçer algún Exerçicio». En diciembre de 1735 hablaron las habas y la votación en el Cabildo deparó la aparición de 8 negras y 23 blancas, ${ }^{62}$ en mayo de 1736, 3 negras y 21 blancas ${ }^{63}$ y en septiembre del mismo año 5 negras y 15 blancas. ${ }^{64}$ En noviembre se volvió a este asunto, puesto que «después de una grave peligrosa enfermedad que avía padecido le continuaban con tanto rigor sus achaques que le imposibilitaban muchas veces salir de la Cama». En el Cabildo «se suszitó la duda de si la concesión de este Punctto debía correr desde oi día de la fha ó empezar después de concluirse el antecedente concedido». ${ }^{65}$

Las «bajas laborales» de muy larga duración enconaban los debates y aguzaban las cautelas para evitar los fraudes, y más cuando tras el PQ se ocultaban turbias manipulaciones y engaños. Así el canónigo Núñez Gamarra, aquejado de «unas terzianas complicadas con Erisipela», comprobó, en octubre de 1737, cómo se le suspendió la determinación del PQ por no venir jurada. ${ }^{66}$ Don Manuel del Regato fue consciente, a la postre, de lo perverso de la praxis de enemistarse con los capitulares. En junio de 1738, quiso prorrogar su «baja». «Se confirió y votó in voce y por el deán se mandaron dar abas, declarando que por la blanca se le Conzedía y la negra se le denegaba y dadas y reguladas parezieron 17 blancas y 17 negras, por lo que se resolvió se diesen nuebamente y pasase a segundo escrutinio y dho Sr Deán mandó se diesen, declarando en la misma forma que por la blanca se conzedía dho punctto de quartanario y por la negra se denegaba, y dadas y reguladas parezieron 17 blancas y 17 negras».67

\footnotetext{
${ }^{61}$ ACC. AC. LR 103, Cabildo del 11 de mayo de 1736, folio 176.

62 ACC. AC. LR 103, Cabildo del 12 de diciembre de 1735, folio 110.

${ }^{63}$ ACC. AC. LR 103, Cabildo del 18 de mayo de 1736, folio 182.

${ }^{64}$ ACC. AC. LR 103, Cabildo del 17 de septiembre de 1736, folio 257.

${ }_{65}$ ACC. AC. LR 103, Cabildo del 12 de noviembre de 1736, folio 295.

${ }_{66}$ ACC. AC. LR 103, Cabildo del 2 de octubre de 1737, folio 512.

${ }^{67}$ ACC. AC. LR 103, Cabildo del 23 de junio de 1738, folio 701.
} 
No importa tanto el desenlace cuanto el empantanamiento en las decisiones y la crispación de fondo en el seno del Cabildo. ${ }^{68}$ Situaciones tan tensas como la vivida entre los capitulares y el canónigo Regato no eran habituales. Por lo general, los prebendados daban, con todas las habas blancas, el consentimiento para que los enfermos más graves recuperaran su salud. Así, el racionero y prior Sebastián de Cosío, según señalaba, en octubre de 1737, el cirujano que le atendió, «havrá dos meses está padeziendo un dolor reumático en la Caveza que le quita el poder Comer y dormir, no haviendo podido lograr su alivio con diferentes medizinas». Aconsejaba prescribir al clérigo que «pase a tomar los aires a su País». ${ }^{69}$

Todas las votaciones de esa época fueron al $100 \%$ comprensivas, solidarias y de habas blancas, no sólo porque la certificación del cirujano o del médico «Venía en forma» cuanto porque el capitular, gravemente afectados por las enfermedades, jamás había dado motivos de queja al Cabildo, salvo los casos de Verde Sañudo, Calderón o Regato Sota. ${ }^{70}$

El canónigo Juan José Jiménez Moreno, en marzo de 1748, solicitó la «baja», aquejado de unas «quartanas que lo mortificaron bastantamente». ${ }^{71} \mathrm{El}$ deán Calderón de la Barca sufrió, en agosto de 1748, unas «tercianas mui molestas» ${ }^{72}$ patología que compartió con el canónigo lectoral, Prieto Bustamante. Este, en octubre del mismo año, exponía en un «memorial» «aver padecido una larga enfermedad y tercianas diarias que le han ocasionado bastante molestia $y$ debilidad». ${ }^{73}$

68 ACC. AC. LR 103, Cabildo del 2 de agosto de 1737, folios 472-481. La secuencia «histórica» de las patologías de Regato permite entrever el sufrimiento del prebendado y el estado de ánimo de sus «compadres» que asistían, quizá impertérritos, a sus largas, aunque justificadas, ausencias. Una carta del canónigo es sintomática de tales circunstancias: «...que desde que llegó a esta tierra asta el día tres de septiembre [1736] pudo vestirse todos los Días y andar alguna Cosa aunque con bastante trabaxo y dho día tres de septiembre».

${ }^{69}$ ACC. AC. LR 103, Cabildo del 11 de octubre de 1737, folio 518. Sobre la percepción del tiempo y el clima según diferentes personas véase Sanz de la Higuera, F. J. 2002. «Alojamiento de tropas en Burgos a mediados del siglo XVIII. Cuarteles, alquileres y hospitales para el Regimiento de Inválidos de Cataluña (1748-1753)», Milicia y sociedad ilustrada en España y América (1750-1800), Actas de las XI Jornadas Nacionales de Historia Militar: Tomo I, 343 (335-360), Sevilla.

70 Véase, por ejemplo, ACC. AC. LR 103, Cabildo del 11 de octubre de 1737, folio 518.

${ }^{71}$ ACC. AC. LR 105, Cabildo del 28 de marzo de 1748, folio 609. La votación con habas deparó que fueran «todas blancas».

72 ACC. AC. LR 105, Cabildo del 19 de agosto de 1748, folio 667.

${ }^{73}$ ACC. AC. LR 105, Cabildo del 11 de octubre de 1748, folio 687. En ambos casos, las habas fueron «todas blancas». Unos años antes, en 1743, deán y lectoral no habían compartido precisamente un mismo plato de alubias sino más bien todo lo contrario, enfrentados de una forma disparatada por el control de una de las instituciones docentes de la ciudad. Véase Sanz de la Higuera, F. J. 2006.«Seminario de San Nicolás (Burgos, 1743): una rectoría apetecible, un litigio aborrecible». BIFG 232: 149-177. 
«Dolores reumáticos» eran la causa de la desazón del canónigo Ramos, «imposibilitado [en noviembre de 1748] de poder venir a residir su Prevenda sin grave detrimento de su salud». ${ }^{74}$ En marzo de 1751, el medio racionero Diego de la Peña ponía en conocimiento del Cabildo que se encontraba muy afectado por una «fiebre Catarral la mayor parte del Ybierno». ${ }^{75}$ Este mismo individuo, en el mes de junio, advertía a los capitulares que sus achaques se habían agravado notablemente «por aversele sobrevenido un fluxo de sangre, repetido Zinco Vezes, en cuia consequenzia está mui débil y Valdado de los Brazos, a causa del Reumatismo que le molesta». ${ }^{76} \mathrm{El}$ sochantre Navarrete, dictaminaron los médicos en febrero de 1751, «ha padezido una larga diarrea de la que ha resultado edema en una pierna». ${ }^{77}$

Frente a la baja actividad del período anterior (1735-1760), entre 1761-1773 se aprecia una tendencia diferente, que se mantendrá el resto del siglo. Con un promedio de casi 9 solicitudes por año -gráficos I y IV-, el doble que en épocas anteriores, y con un promedio de 5 prórrogas/año - gráfico II-, pasamos desde cero (1760) los 19 de 1772, con la gran epidemia de tercianas de 1766 como causa principal de enfermedad y de muerte. El $57.1 \%$ de las «bajas» de ese año acaecieron por esta patología.

1761-1773 supone un descenso significativo de las «quartanas», hasta el $17.3 \%$ desde el $44.9 \%$ de la etapa anterior -gráfico III-. Hay también un incremento substancial de las «tercianas» hasta el $14.6 \%$, no menos importante que el de las afecciones por reuma, artrosis y artritis $(12.4 \%)$ y las «otras» enfermedades $(50.3 \%)$. La gota y la podagra sufren un ligero retroceso. Fueron solo un $5.4 \%$. Frío y humedad pasaron en este período factura a los prebendados catedralicios, causando asma, problemas pulmonares y dolores articulares.

Hay muchos ejemplos. Los más significativos son pruebas fehacientes de cómo se transita desde una estricta exigencia inicial, con la demostración de la enfermedad que dio nombre al «Punctto», es decir, las «quartanas», hasta una visión más abierta y permisiva de la «baja laboral» catedralicia, en la que se aducían padecimientos novedosos y diversos. De hecho, se disparó el volumen de los PQ, y sus prórrogas, y también, de una manera aparentemente contradictoria, la oposición de algunos capitulares, con las habas negras como herramientas frente a este relajamiento. Los procesos a los deanes Rubín de Celis y Calderón de la Barca, al abad de San Quirce, Ramón de Larrínaga, y los canónigos Haedo, Carreras, Méndez y Carrillo Acuña, son signos evidentes de que

\footnotetext{
74 ACC. AC. LR 105, Cabildo del 27 de noviembre de 1748, folio 709. Dicho canónigo se encontraba postrado en su lecho de Oviedo, sin posibilidad de regresar a Burgos.

75 ACC. AC. LR 106, Cabildo del 29 de marzo de 1751, folio 300.

76 ACC. AC. LR 105, Cabildo del 9 de junio de 1751, folio 333. Habas «todas blancas».

77 ACC. AC. LR 107, Cabildo del 28 de febrero de 1757, folio 167.
} 
el «Punctto de Quartanario» estaba desembocando en manifiestos procesos que superaban la mera «baja laboral» transitoria y se convertían en incapacidad laboral permanente. La jubilación, tras 30 años de residencia, se solapaba con la imposibilidad de acudir físicamente a la Catedral.

Algunos capitulares alcanzaron, en la práctica, el PQ perpetuo, cuya fecha de caducidad implicaba inexcusablemente el óbito del clérigo. Otros hubieron de conformarse con situaciones bastante más severas y las prórrogas se encadenaban unas con otras.

Descuella el canónigo Juan Manuel del Río, obligado en febrero de 1767, a pedir el «Punctto de Quartanario» y varias prórrogas por los sufrimientos causados por unas «peligrosas quartanas». ${ }^{78}$ Se hallaba en igual situación Ortíz de Taranco. El médico señalaba, en el otoño de 1763, que «en los próximos meses pasados de Agosto y Septtiembre ha padecido unas tercianas y le han repettido en dibersas ocasiones, añadiéndose a estto ottros perniciosos efectos de hipocondría (...) necesitando para su Combalezencia precaberse de ttoda humedad y frialdad y hazer ejercicio a oras Compettentes». ${ }^{79}$

El racionero Agustín Arnaiz estuvo aquejado, en el otoño de 1764, de una «gravísima inflamazión de intestinos». ${ }^{80}$ En febrero del año siguiente los médicos le trataban de una «enfermedad de diez días de Calentura continua y hallándose con la edad de 70 años y una estilazión ardiente» se temía por su vida.$^{81}$ El canónigo Garro, a través de un memorial leído en el Cabildo en diciembre de 1765 «expone haver padecido un gravísimo cólico nephrítico con supresión de orina», a resultas del cual «está mui débil y mal Convalecido y

${ }^{78}$ ACC. AC. LR 110, Cabildo del 20 de febrero de 1767, folio 80. Se le concedió prórroga en mayo «en attención a sentirse con pocas fuerzas y bastante quebrado de salud (...) [dado que] ha padecido largo tiempo una Quartanas perniciosas de que se halla alguna cosa aliviado pero para su perfecto restablecimiento necesita salir a hacer algún exercicio a horas cómodas y abstenerse de la asistencia al Choro, que le será mui perjudicial».

${ }^{79}$ ACC. AC. LR 108, Cabildo del 24 de octubre de 1763, folio 483 y del 31 de octubre de 1763, folio 485. Las habas obtenidas en la ineludible votación fueron 2 negras y 27 blancas.

${ }^{80}$ ACC. AC. LR 109, Cabildo del 17 de septiembre de 1764, folio 89.

${ }^{81}$ ACC. AC. LR 109, Cabildo del 17 de febrero de 1766, folio 385. En septiembre de 1770 se le diagnosticó un «apostema de pulmón con fiebre aguda de la que ha quedado extremadamente débil». ACC. AC. LR 111, Cabildo del 3 de septiembre de 1770, folio 624. En mayo de 1772, se dolía de «graves inflamaciones en las piernas con algunas llagüelas de escamas en su circunferencia, quedando bastante debilidad de ellas». ACC. AC. LR 112, Cabildo del 8 de mayo de 1772, folio 281. En marzo de 1773 el cirujano Villalba señaló que «aún prosigue una efusión o evacuación de materia serosa linfática por la que ha libertado de aquella opresión y carga al Pecho que solía padecer, la que nezesita se conserbe por lo que debe huir de estazión fría como causa apta para producir un methastasis o transtación de dha evacuación, el que podría ocasionar grave ruina en su salud y vida». ACC. AC. LR 112, Cabildo del 29 de marzo de 1773, folios 503-504. En septiembre de 1764, sufrió una «gravísima inflamación de intestinos». ACC. AC. LR 109, folio 89. 
para su restablecimiento y precauzión de un nuevo insulto tiene por preciso [el médico que la atendía] que salga de casa y haga algún exercicio a horas commodas (...) absteniéndose de la asistenzia a Choro, que le será perjudizial mientras no se recobre perfectamente». ${ }^{82}$

El canónigo Bartolomé Huidobro Garoña tuvo graves problemas pulmonares. Hubo de solicitar la «baja laboral» por «el accidente que ha padecido este Ymbierno, por cuio motibo necesita tomar medicinas, hacer exercicio y abstenerse de la asistencia a la Yglesia», dado que se hallaba dolorosamente afectado por «una destilación furiosa al pecho, de cuia resulta ha quedado el pulmón tan débil que a qualquier movimiento violento o subida a lugar alto se fatiga demasiado y le amenaza la sofocación, por lo que necesita medicinarse y hacer exercicio a pie y a caballo a horas cómodas, entendiéndose este tpo desde las seis de la mañana hasta las nueve, absteniéndose interín de la asistencia a la Iglesia, cuia intemperie es totalmente opuesta a la curación [y] se expone a contraher una asthma incurable».83

Del canónigo Castro se dice, en julio de 1766, «haver padecido un lettargo con proximidad a ultimarse en apoplejía». ${ }^{84} \mathrm{El}$ arcediano de Burgos Pedro Tomé Carrera tenía, entre otras debilidades, ${ }^{85}$ un profundo sufrimiento, especialmente intenso al final del invierno de 1768 , con «el afecto de podagra que padece y antes de ahora ha padecido», por lo que los médicos aconsejaban «para su total restablecimiento guardar en este tiempo la Cama por la mañana y hacer algún exercicio moderado de pasear por las tardes».86 A su tío, herma-

${ }^{82}$ ACC. AC. LR 109, Cabildo del 16 de diciembre de 1765, folios 353-354.

${ }^{83}$ ACC. AC. LR 111, Cabildo del 8 de junio de 1770, folio 564. En este mismo derrotero se hallaba el racionero sochantre Fernando Pablos, aquejado de un «afecto de Asma espasmódico convulsivo con retoque de Corazón (...) que quasi le impide la respirazión y sosiego». ACC. AC. LR 112, Cabildo del 29 de marzo de 1773, folio 496. Sobre la influencia de la climatología en múltiples aspectos de la economía y la salud, véase Alberola Romá, A. 2010. Quan la pluja no sap ploure. Sequeres i riuades al País Valencia en l'edat moderna, Valencia y del mismo autor 2010. «»No puedo sujetar la pluma de puro frío, porque son extremados los yelos»: el clima en la España de los reinados de Felipe V y Fernando VI a través de la correspondencia de algunos ilustrados». Investigaciones Geográficas, 49: 65-88. Véase también Fernández García, A. 1991. «La enfermedad como indicador social. Consideraciones metodológicas», en Castillo, S. (Coord.), La historia social en España. Actualidad y perspectivas. Actas del I Congreso de la Asociación de Historia Social: 401-428, Madrid.

${ }^{84}$ ACC. AC. LR 109, Cabildo del 11 de julio de 1766, folio 506.

85 Véase Sanz de la Higuera, F. J. 2009. «Carrera eclesiástica y algunos deslices de Felipe del Hoyo y Pedro Celestino Tomé, arcedianos de Burgos (1731-1784)». Hispania Sacra 124: 649-690. La deshonestidad de algunos componentes del Cabildo catedralicio era manifiesta y conocida, criticada y denunciada por sus vecinos y «compadres» clérigos. Se trata de clérigos que lo eran sin querer serlo y que traicionaban conscientemente sus obligaciones.

${ }^{86}$ ACC. AC. LR 110, Cabildo del 15 de febrero de 1768, folio 395. En septiembre de 1759 ya había sufrido una «larga y prolongada artthética»-ACC. AC. LR 107, Cabildo del 17 de septiembre de 1759, folio 598- y julio de 1773 sufrirá «unos Dolores Reumáticos articulares (...) [que] por su rebeldía y mo-

Hispania Sacra, LXIV

130, julio-diciembre 2012, 661-719, ISSN: 0018-215X, doi: 10.3989/hs.2012.020 
no de su madre, doña Josefa, el canónigo Felipe Carrera, se le concede, en junio de 1761, el «Punctto de Quartanario perpetuo por ymposibilidad de acudir a la Iglesia y en attenzión a ttener Quarenta años de Iglesia y allarse en hedad abanzada como la de Settenta años».87

El deán Calderón de la Barca, aquejado, en el verano de 1761, de «una summa devilidad de caveza y otros síntomas por los que se está medizinando», suspiraba por un estatus similar, pero murió sin conseguirlo. ${ }^{88}$ No fue el único. En mayo de 1773, el racionero Agustín Arnaiz persistía en sus males anteriores, agravados con una «evacuazión seroso limphática [que] puede ocasionarle detrimento de la vida o cerrados los poros y por ello impedida la evacuazión un estrago grande en la pierna por lo que debe huir de todo aire y estación fría». Los médicos y «los Zirujanos Dicen que la fluxión durará el tiempo que durase la vida y por no molestar a VS a menudo suplica que, si fuere de su agrado, le conceda el Punctto de Quartanario perpetuo». El 10 de septiembre de 1773 el Cabildo no estaba por la labor y la democracia de las habas indicó, por 2 blancas y 17 negras, que se le negaba el PQ perpetuo. ${ }^{89}$ Quien sí accedió al PQ sin limitación de tiempo - aunque con la «calidad de que al empezar a ganarse la Prebenda de cada un año presente Certificazión deel Médico que acredite subsistir las mismas causas que ahora» - fue el maestre escuela Río Cantolla. En enero de 1773 sufrió un «desenfreno de destilazión al pecho de que está alivia-

lestia le han inducido tan mala disposición que sólo una dieta prudente podrá precaver la recaída y tiene por preciso salga de Casa a hacer exercicio a horas cómodas». ACC. AC. LR 112, Cabildo del 23 de julio de 1773, folios 553-554. La ingesta de carnero, vianda «principal en la dieta de un eclesiástico noble» generaba, en algunas familias, graves ataques de gota. Véanse los comentarios de Cabeza Rodríguez, A. 1996. Clérigos y señores. Política y religión en Palencia en el Siglo de Oro: 327, Palencia. Los Pedro Tomé, padre e hijo, estuvieron aquejados de podagra gran parte de su existencia. Lo agrio de su carácter y múltiples episodios de malhumor y de enfado mayúsculo lo atestiguan. Véase también Pérez Samper, M. A. 1997. «Fiesta y alimentación en la España Moderna: el banquete como imagen festiva de abundancia y refinamiento». Espacio, Tiempo y Forma 10: 55 (53-98).

${ }^{87}$ ACC. AC. LR 108, Cabildo del 22 de junio de 1761, folio 124. Como se recalcará de forma más pormenorizada en el próximo apartado, a Felipe Carrera se le concedió el PQ perpetuo «sin limitación de tiempo a Claustro deel Cavildo y asistiendo a aquellas oras que pueda, según le dicte su conciencia sin perjuizio de su Salud». La concesión del PQ perpetuo a los canónigos Carrera y Castañeda llevaba añadida la condición anual de persistir la enfermedad y «que solamente ganasen distribución desde noviembre hasta mayo inclusive, encargándoles sobre su conciencia la asistencia quando se la permittiessen sus dolencias», punto que Castañeda «protextó» enérgica y airadamente. ACC. AC. LR 108, Cabildo del 6 de junio de 1776, folios 655-656. El canónigo Castañeda se había jubilado en junio de 1764 «en tan abanzada hedad como la de 85 años, bastante ajado de salud, habiendo residido más de 73 años su Prebenda con la punttualidad que es ttan notoria». ACC. AC. LR 109, Cabildo del 1 de junio de 1764, folio 31 .

${ }^{88}$ ACC. AC. LR 108, Cabildo del 3 de julio de 1761, folio 131.

${ }^{89}$ ACC. AC. LR 112, Cabildo del 5 de mayo de 1773, folios 511-512 y 10 de septiembre de 1773, folio 654 
do pero de resulta se ha aumentado la indisposizión antiguo de la vista».90 Un mes más tarde, le fue prorrogada la «baja» «sin haver experimentado alivio en su dolencia, antes bien aumento de disminución en la vista que le impide el gusto de asistir al Coro», indisposición ocular «la que cada día va en aumento y amenaza una Ceguera total». ${ }^{91}$

Entre 1774-1784 se pasa a una aparente tranquilidad, desde las 18 y 19 solicitudes -29 y 35 si contamos también las prórrogas- de 1772 y 1773 hasta las 2 peticiones de 1784. El comportamiento clínico del Cabildo y de la mortalidad en la población burgalesa, después del dramático episodio de 1763, presentan una tendencia similar - gráficos I y V-, característico de un compás de espera o período de suavización tras la catástrofe. El final del siglo fue bastante calamitoso. El promedio de solicitudes de «baja laboral» se disparó hasta casi 11 por año, con un número similar de prórrogas/año. Se estabilizaron las afecciones por «otras» enfermedades ${ }^{92}$ ( $43.8 \%$ de las patologías). Decrecieron, de nuevo, las «quartanas» (hasta el $10.9 \%$ ) y de manera elocuente la gota $(0.4 \%)$ pero repuntaron, y mucho las «tercianas» $(31.1 \%)$ y las problemáticas relacionadas con el reuma, las artritis y las artrosis $(31.1 \%)$-gráfico III-.

El canónigo Portillo protagonizó una «baja laboral» en junio de 1775 por «unas tercianas fuertes que en su invasión fueron sencillas y repitieron dobles y aunque se halla libre de ellas, a beneficio de la Quina, para convalecerse juzga preciso salga de Casa a hacer moderado egercicio» ${ }^{93}$. El racionero y cura de Santiago de la Capilla José Manzanedo se vio aquejado de unas «tercianas malignas [de que] se halla en una convalescencia muy tarda y penosa (...) tercianas petinaces a cuia consequencia experimenta conocido atraso de fuerzas» ${ }^{94}$.

90 ACC. AC. LR 112, Cabildo del 29 de enero de 1773, folio 466.

91 ACC. AC. LR 112, Cabildo del 19 de febrero de 1773, folio 474. En junio de 1774 persistía en su patología ocular - ACC. AC. LR 113, Cabildo de 1 de junio de 1774, folios 99-100. Véase Sanz de la Higuera, F. J. 2012. «Aproximación a los problemas de visión y el uso de anteojos en el Burgos de mediados del siglo XVIII». El Futuro del Pasado 3: 371-401.

92 Catarros, constipados, asma y afecciones pulmonares, erisipelas, perlesías, tumores, problemas en los riñones, bocio, etcétera.

93 ACC. AC. LR 113, Cabildo del 9 de junio de 1775, folio 352. Eran para él una enfermedad contumaz. En agosto de 1772, estuvo aquejado de unas «tercianas subintrantes perniciosas»-ACC. AC. LR 112, Cabildo del 14 de agosto de 1772, folio 333-; en octubre había empeorado bastante, al haber «reincidido en las tercianas dobles»-ACC. AC. LR 112, Cabildo del 26 de octubre de 1772, folio 388y en enero de 1773 continuaba en la «convalecencia de las indisposiciones penosas y tercas de que antes tiene certificado»-ACC. AC. LR 113, Cabildo del 25 de enero de 1773, folio 454-.

94 ACC. AC. LR 113, Cabildo del 7 de julio de 1775, folio 376. En julio de 1776 se complicó exponencialmente su existencia al verse aquejado de «unas Calenturas con dolores Reumáticos que le han dejado bastante debilitado»-ACC. AC. LR 114, Cabildo del 5 de julio de 1776, folio 15-. En marzo de 1789, y ascendido ya a maestro de capilla, sufrió «una destemplanza de caveza con destilazión acre y grande pervigilio»-ACC. AC. LR 119, Cabildo del 23 de marzo de 1789, folio 377-, que en diciembre de 1792 era «una determinación quantiosa de humor acre en la superficie de la Caveza»

Hispania Sacra, LXIV

130, julio-diciembre 2012, 661-719, ISSN: 0018-215X, doi: 10.3989/hs.2012.020 
Afectado de «quartanas dobles», en el otoño de 1782, se encontraba el maestro de capilla y racionero Antonio Abadía, quien, a pesar de su «licuación serosa nocturna, precedida de una orripilación o rigorcillo vespertino, repetidos en dos días seguidos, con algún respeto a tendencia a las quartanas dobles» ${ }^{95}$ [según diagnosticaba el galeno zaragozano Antonio Gargallo, médico del Hospital General y Militar de Nuestra Señora de Gracia], aún le quedaba tiempo para actuaciones deshonestas ${ }^{96}$.

El maestro de capilla Hernández Yllana, jubilado desde octubre de 1774, tras 44 años de residencia, ${ }^{97}$ hilaba una patología tras otra. Si en febrero de 1775 la truculencia era «un copioso fluxo de sangre de narices, el que se ha causado una destemplaza grande (...) [y] notable debilidad de caveza», 98 en diciembre de 1775, el problema era «una Perlesía imperfecta de lengua con amagos de hacerse universal y perfecta» $99 \mathrm{y}$, en junio de 1777 , persistía «la debilidad de Nervios y flaqueza en las Piernas». 100 Un «accidente de Vocio» fue diagnosticado por José Victoriano Gómez ${ }^{101}$ al racionero sochantre Santiago

-ACC. AC. LR 120, Cabildo del 10 de diciembre de 1792, folios 485-486- y en marzo de 1796 le había llevado a sufrir «reciamente un dolor de cabeza periódico que pide la mayor atención»-ACC. AC. LR 122, Cabildo del 10 de marzo de 1796, folio 191-.

95 ACC. AC. LR 117, Cabildo del 30 de septiembre de 1782, folio 37. El diagnóstico fue realizado por el galeno zaragozano Antonio Gargallo, médico del Hospital General y Militar de Nuestra Señora de Gracia. Las «quartanas dobles» fueron tratadas con quina. Véase, entre otras muchas, Frías Núñez, M. 2003.«El discurso médico a propósito de las fiebres y de la quina en el Tratado de las calenturas (1751) de Andrés Piquer». Asclepio 55/1: 215-233, Fronfría Díaz, J., Jiménez Artacho, C. y Fernández Pérez, J. 2001. «La corteza de la quina. Un remedio universal», Estudios de Historia das Ciencias e das Técnicas: tomo II, 837-846, Pontevedra, Hernando, T. 1982. «La quina en el siglo XVII», Dos estudios históricos (Vieja y Nueva Medicina): 171-223, Madrid y Alberola Romá, A. y Bernabé Gil, D. 1998-1999...95-112. Véase también la bibliografía sobre paludismo en la nota 23. Descuellan también, el excelente, imprescindible y ya clásico trabajo de Peset Reig, M. y J. L. 1978... 7-28, Guerra, F. 1977.«El descubrimiento de la quina» Medicina e Historia 69: 7-26 y el no menos brillante aunque lamentablemente bastante desconocido Núñez Roldán, F. 1988. «Enfermedades, hospitalidad y terapéutica en las comarcas onubenses a fines del Antiguo Régimen». Huelva en su historia 2: 451-490, modelo de metodología, indagación de archivo y saber hacer historia.

${ }^{96}$ ACC. Libro 135, folio 123. «Mro Capilla: Criminal sobretrato con mugeres». Véase Sanz de la Higuera, F. J. 2006. «En casa [, cama] y compañía». Yacer a lomos del XVIII en los hogares eclesiásticos burgaleses». Hispania Sacra 118: 545-577 y Sanz de la Higuera, F. J. 2009...649-690.

97 ACC. AC. LR 113, Cabildo del 24 de octubre de 1774, folio 187.

98 ACC. AC. LR 113, Cabildo del 1 de febrero de 1775, folio 258.

99 ACC.AC. LR 113, Cabildo del 15 de diciembre de 1775, folio 518. La enfermedad le ocasionaba una notable «devilidad de Caveza y nervios».

100 ACC. AC. LR 114, Cabildo del 23 de junio de 1777, folio 275. «... aunque a beneficio del tiempo se halla menos mal y para que consiga el alivio posible conviene que salga algunos ratos de Casa y se abstenga de la asistencia a la Iglesia, pues de lo contrario está pronto a imposibilitarse totalmente». El maestro de capilla Hernández Yllana falleció el 9 de mayo de 1780. ACC. Libro 39. Posesiones.

${ }^{101}$ López Gómez, J. M. 1996. Cirugía ilustrada en Burgos: la figura y la obra de José Victoriano Gómez (1773-1819), Burgos. 
Martínez como afección que le imposibilitaba y requería de la «baja laboral» y de múltiples prórrogas posteriores. ${ }^{102}$

El también racionero y músico Antonio de Diego padecía, en julio de 1776, «una úlcera virulenta en ambas piernas con grave inchazón edematoso acre en ellas acompañada de fuerte escozor y dolor» ${ }^{103}$ y el canónigo Carrillo Gutiérrez, en julio de 1777, «... unas flusiones Rheumáticas, especialmente en el Pecho y estomágo para cuia curación necesita tomar leche de cabra».104 «Insultos epilépticos o de Alferecía en el espacio de tres meses, cuyo accidente es por naturaleza temible, periódico y pide más profunda acción» era el leit motiv de la «baja laboral» del canónigo Méndez en septiembre de 1777.105

En mayo de 1778, el racionero López Merino esgrimía como aval para la «baja» haber padecido una «grave herisipela en la Cara y Cabeza de cuya resulta le ha quedado ésta débil y ofendida con influxión inflamatoria al ojo derecho y parte de la frente». ${ }^{106}$ En diciembre de 1783, el racionero Ordóñez alegaba «una hernia sarcocele cuyo volumen y peso le ocasionaba vivos dolores e inflamación, de cuyos accidentes ha estado en Cama 40 días». ${ }^{107}$

Los años comprendidos entre 1785 y 1799 reflejan las tendencias manifestadas a lo largo de la centuria. Se alcanzan los máximos paroxismos en el PQ -el máximo del siglo XVIII- en las 29 solicitudes de 1790, que fueron 68 actuaciones si también contemplamos las 39 prórrogas solicitadas y ajustadas -gráfico I y II- y los más profundos desplomes. En 1794, las peticiones iniciales fueron únicamente 8.108

Desde una perspectiva general, el promedio fue escalofriante, con 15 PQ iniciales y 18 prórrogas/año, datos que consolidan la reflexión sobre el incremento de los memoriales de súplica y las concesiones de las «bajas laborales»- gráfico IV -. En Córdoba, hubo una tendencia similar. «Desde la década postrera del setecientos se redoblaron las solicitudes de licencia», lo que determinó que no fuera casual «que poco después se restringiera de forma considerable». ${ }^{09}$

102 ACC. AC. LR 113, Cabildo del 14 de junio de 1776, folio 651.

${ }^{103}$ ACC. AC. LR 114, Cabildo del 29 de julio de 1776, folio 25.

104 ACC. AC. LR 114, Cabildo del 14 de julio de 1777, 286. Además conveniente, según dictaminaban los médicos «... hacer exercicio en horas commodas para lo qual es incompatible la continua asistencia a dha Iglesia, particularmente por las mañanas».

105 ACC. AC. LR 114, Cabildo del 15 de septiembre de 1777, folio 331. «... franqueándose las salidas de su Casa o ausencias de la Ciudad que tenga por oportunas y porque requiere conservar un ánimo quieto y tranquilo sin mezclarse en asuntos de consideración...».

106 ACC. AC. LR 114, Cabildo del 22 de mayo de 1778, folios 547-548.

107 ACC. AC. LR 117, Cabildo del 5 de diciembre de 1783, folios 377-378.

${ }^{108}$ Bien es cierto que en ese año se alcanzó el máximo de prórrogas, nada menos que 44.

${ }^{109}$ García-Cuevas Ventura, J. 1996: 36. 
El reparto del peso específico y relativo de las patologías sufridas por los prebendados depara una nítida aseveración de los análisis esgrimidos en las etapas anteriores. Las «quartanas» alcanzan su mínimo histórico en el siglo, con un modesto $11.1 \%$, la gota repunta poderosamente hasta el $4.2 \%$ y las «tercianas», las afecciones reumáticas y las «otras» enfermedades se asientan alrededor del 20.3 y el $34.8 \%$, respectivamente -gráfico III-.

El enorme incremento en las súplicas de PQ y sus correspondientes prórrogas hizo que el Cabildo, a partir de mayo de 1790, votara por separado la concesión de la «baja laboral» y la asistencia o no a las horas canónicas. El fermento de esta novedosa herramienta de control vino de la mano de la problemática médica generada por «la Rheuma crónica» que aquejaba al canónigo Cacho, a quien se concedió el PQ con todas las habas blancas a principios de noviembre de 1789 pero se denegó, en mayo del año siguiente «la dispensa para mientras las horas de choro». En otras palabras, las 15 habas negras ridiculizaron a las 4 habas blancas e impedían que los ejercicios fuera de casa en horas cómodas se extendieran también a las horas canónicas. ${ }^{110}$

Hubo también casos especialmente rigurosos, que avalan nuestra hipótesis Descuellan los «vicios orgánicos en el esóphago que a tiempos le impiden la deglución» que traían por la calle de la amargura, en los inicios del verano de 1786, al canónigo Lino de Frías, ${ }^{111}$ los padecimientos del arcediano de Lara, Juan Antonio de Salamanca, afectado, en el invierno de 1789, de «una calentura linphática por destemplanza del celebro con desenfreno de la destilación», ${ }^{112}$ las horribles consecuencias que se derivaban de la «Cicatriz de la grande Herida que rezivió en la Cabeza (...) Contrahidos los Músculos del Cuello» sufrida por el racionero y sochantre de día García del Río en el verano de $1790,{ }^{113}$ «la ardiente destilación ulcerosa que le cahe a la garganta» del canónigo Lapeña en enero de 1791,114 el «infarto bilioso en las entrañas del baxo bientre» del racionero Vicente de la Puente en el verano de $1795^{115}$ o la «diatesis atrabiliaria a los ypocondrios» del racionero Varona en septiembre de 1799. 116

110 Por mucho que lo dijeran los médicos en sus certificados -dichos profesionales seguían apostando por ocupar las horas de coro-, el Cabildo entendía todo lo contrario y así lo legisló. ACC. AC. LR 119, Cabildo del 4 de noviembre de 1789, folio 509 y Cabildo del 31 de mayo de 1790, folio 2.

111 ACC. AC. LR 118, Cabildo del 7 de junio de 1786, folio 375. En abril de 1785, dicho canónigo había padecido «una fiebre limphatica con decubito al pecho» de notable gravedad -ACC. AC. LR 118, Cabildo del 22 de abril de 1785, folio 206-.

112 ACC. AC. LR 119, Cabildo del 10 de diciembre de 1789, folio 531.

113 ACC. AC. LR 120, Cabildo del 27 de agosto de 1790, folio 41.

${ }_{114}$ ACC. AC. LR 120, Cabildo del 11 de noviembre de 1790, folio 74.

115 ACC. AC. LR 122, Cabildo del 8 de junio de 1795, folio 77.

116 ACC. AC. LR 122, Cabildo del 5 de julio de 1795, folio 90. 
Finalmente, y para cerrar este relato, veamos el caso del canónigo José Redondo Portillo, a quien se le diagnostica «una Cólera morbo vehemente con afecto convulsivo de cuyas resultas ha quedado muy débil», ${ }^{117}$ patología que anuncia el final del predominio de las «tercianas», de la enfermedad capital del Setecientos, y el surgimiento de las primeras ocurrencias de las patologías hegemónicas del siglo XIX, con el cólera y la fiebre amarilla como «chairas» imprescindibles de la guadaña letal de la historia contemporánea.

La década de los 90, al final del XVIII, estuvo preñada, al igual que la primera, de debates y decisiones sobre los modos y maneras de cumplimentar el PQ y sus prórrogas. En mayo de 1790, se revisaba «la facultad a los Quartanarios de salir de casa interín las horas canónicas», señalándose que ello «no debía hacerse sin urgentísima e inevitable causa» y que «en el caso de que vengan a la Iglesia [léase Catedral], aún a decir misa, están obligados después a entrar en el Coro y no lo haciendo deben perder su Punctto», ${ }^{118} \mathrm{Al}$ año siguiente, en julio de 1791, y ante la avalancha de «bajas», se replanteó igualmente el «quando debe empezar a contar el término de los Quartanarios», en especial de algunos capitulares con 2 meses de «baja». Las habas, con 17 blancas y 1 negra, determinaron que «debe correrse el uso del Punctto de Quartanario desde el citado día de Cavildo ordinario, aunque no se tenga por ocurrencia de festividad u otro motivo, presentándose en lo sucesibo la Certificación a este fin al Sr Deán o Presidente», 119

En enero de 1793, los archivistas y el Doctoral hubieron de encargarse, a petición del Cabildo, de indagar sobre «si los que piden Punto de Quartanario para fuera de la Ciudad deben apuntarse las Horas de los días que se detengan en ella [sin salir]». Reconocido el Archivo, «no se hallaba ejemplar alguno de que assí se hubiese determinado ni tratado», circunstancia que evidencia lo novedoso de todo el proceso, ${ }^{120} \mathrm{El}$ asunto había emergido meses antes, en noviembre de 1792, cuando, merced a un memorial de un canónigo, reverdecía el debate «sobre lo que se debe ganar para fuera no saliendo por algún tiempo». Campo Quevedo suplicaba se le aclarase qué ocurría «quando algún Señor pide para fuera de la Ciudad y no camina inmediatamente».

¿Qué sucedía esos días y qué pasaba con la porción de prebenda y las distribuciones de ese momento?, ${ }^{121}$ En febrero de 1793, escuchadas todas las partes,

\footnotetext{
117 ACC. AC. LR 119, Cabildo del 26 de septiembre de 1788, folios 265-266.

118 ACC. AC. LR 119, Cabildo del 14 de mayo de 1790, folios 598-599.

${ }^{119}$ ACC. AC. LR 120, Cabildo del 15 de julio de 1791, folio 203.

${ }_{120}$ ACC. AC. LR 120, Cabildo del 11 de enero de 1793, folios 520-521.

${ }^{121}$ ACC. AC. LR 120, Cabildo del 12 de noviembre de 1792. Al margen de las Actas de ese día se lee, en dicho apunte, la siguiente llamada de atención: «Sobre lo que se debe ganar para fuera no saliendo por algún tiempo».
} 
se resolvió «Que quando a algún Señor se conceda Puncto de Quartanario para fuera de la Ciudad y se detubiese en salir algunos días, si en la actualidad estubiese gozando el Puncto para dentro gane las Distribuciones los días que le resten de ese Punto de adentro tan solamente, con tal que cumpla lo que previenen los Estatutos». ${ }^{122}$

La problemática era peliaguda y, en la práctica, se innovaba sobre la marcha. Ello creaba resquemores y tensiones. De hecho, en agosto de 1797, retornó al plenario capitular el debate sobre «el modo de concederse», es decir, «si el Puncto de Quartanario se ha empezar a gozar precisamente desde el día que se concede el Use por el Cavildo según costumbre antigua o ha de empezar el goze desde la fecha de la Certificación o desde que se pone el Memorial en poder del Señor Deán». El tono posibilista y escolástico era aterrador. El Cabildo dudaba y, como era lo habitual, se aplazó la toma de decisiones hasta que los Archivistas y Apuntadores no recorrieran, de nuevo, los libros de Actas en busca de jurisprudencia, es decir, ese «histórico» en el que «se observe el últtimo estado si ocurriese algún caso de estta natturaleza». ${ }^{123} \mathrm{El}$ silencio de las Actas capitulares es sintomático de la hartura que causaban tales contenciosos y el gasto de energías que suponía.

\section{DEANES, ABADES Y CANÓNIGOS CON ACHAQUES HABITUALES.}

Un recorrido sistemático y detenido por las ausencias de varios miembros eminentes del Cabildo catedralicio burgalés patentiza algunas de las diferentes patologías sufridas por sus prebendados y los «Punctos de Quartanario» que gozaban. Las «bajas» evitaron que las enfermedades les dejaran en la indigen-

122 ACC. AC. LR 120, Cabildo del 25 de febrero de 1793, folio 535. Al margen se advierte «Quartanarios para fuera, se declara los que deben ganar». El protocolo capitular exigía efectuar un «Cotejo de los Punttos Mayores y Menores e informasen de la práctica en orden a lo que deben ganar» quienes tuvieran PQ para fuera. El «affaire» estaba ligado directamente a la petición de «baja laboral» solicitada por el canónigo Isla el 25 de junio de 1790, aquejado de problemas renales y reumatismo, que le habían obligado a ir «a tomar las aguas de Belascuain [Navarra] -ACC. AC. LR 120, Cabildo del 25 de junio de 1790, folio 17-. Los días 25 y 26 de junio «le apuntan horas, en el 27 y Siguientes no le apuntan las horas menores, pero se anota que en los Once días antteriores está apunttado con una $Q$ de Punctto de Quarttanario para adentro, no obstante que según resulta del Libro Redondo sólo tenía prorrogación deel hasta el día 13». Similares situaciones se repiten posteriormente con él y otros capitulares. Por ejemplo, el canónigo Lapeña -aquejado de ulceraciones en la garganta-, quien el 7 de enero de 1791 pidió «punto para fuera, en el 6 y 7 gana Prebenda y distribuciones y en el 8 y 9 pierde Prebenda y en el 10 se le apunta con Punctto de Quartanario y pierde Distribuciones».

${ }^{123}$ ACC. AC. LR 122, Cabildo del 9 de agosto de 1797, folio 461. De manera reiterada, obsesiva e insistente, ante el exceso de peticiones, nos topamos en las Actas capitulares con llamadas del siguiente tenor: «Punctto de Quartanario, sobre el modo de concederse». 
cia y el desamparo. La institución les aseguraba la percepción de sus prebendas. ${ }^{124}$ Durante su ausencia justificada del Coro y de las reuniones semanales, en la convalecencia cumplían las prescripciones médicas, hacían ejercicios fisioterapéuticos, acudían a los balnearios a tomar las aguas...lejos de las frialdades y las incomodidades de su trabajo.

Examinaré algunos casos especialmente conflictivos. Dos de ellos fueron deanes y canónigos, don Bernabé Rubín de Celis (1713-1736) y don Alonso Calderón de la Barca (1736-1773). ${ }^{125}$ Don Ramón de Larrínaga y Arteaga fue canónigo y dignidad capitular, abad de San Quirce (1727-1773). Don Felipe Carrera (1744-1771), don Diego de Haedo (1744-1780), don Miguel Méndez (1776-1782) y don Alonso Carrillo y Acuña (1738-1779) fueron canónigos y don Antonio de Diego (1731-1782) fue racionero. Trataré además de las patologías y vicisitudes de otros capitulares, en especial de los que, por unas razones u otras, estuvieron aquejados enfermedades y su comportamiento afectó al Cabildo, a veces de forma traumática. ${ }^{126}$

Don Bernabé Rubín de Celis se posesionó del deanato, en calidad de coadjutor, en 1713 de manos de su tío don Pedro Rubín de Noriega (1703-1713), individuo «de bastante edad y con muchos achaques». ${ }^{127}$ En 1736, contando con

${ }^{124}$ Barrio Gozalo, M. 2005. Iglesia y sociedad en Segovia. Siglos XVI-XIX, Valladolid y Bartolomé Martínez, G. 2010. Los clérigos a la greña: 177-196, Alicante. Véase también Irigoyen López, A. 2000. Entre el cielo y la tierra, entre la familia y la institución. El Cabildo de la Catedral de Murcia en el siglo XVII, Murcia.

125 Sobre deanes, véase, entre otras, las reflexiones de Rodríguez Sánchez, A. 2000. «La clientela capitular del deán de Coria a finales del siglo XVI», en Aranda Pérez, F. J. (Coord.), Sociedad y élites...: 47-75, Cuenca, Soler Pascual, E. 1994. «Perfil biográfico de Miguel Javier de Beramendi y Eleta, deán de la Catedral de Valencia (1782-1833)», en Martínez Ruiz, E. y Suárez Grimón, V. (Eds.), Iglesia y sociedad en el Antiguo Régimen, III Reunión científica de la asociación Española de Historia Moderna, Las Palmas de Gran Canaria, 1994, vol. I, 197-203 y Díaz Rodríguez, A. J. 2009. «Las casas del deán don Juan de Córdoba: Lujo y clientela en torno a un capitular del Renacimiento». Hispania Sacra 123: 77-104.

126 Sus estancias y ausencias marcaron de una manera extraordinaria la vida colegiada de los componentes de dicha institución. Sus problemáticas influyeron en el «imaginario social» de la Catedral burgalesa. Véanse los excelentes análisis de Álvarez Santaló, L. C. 2000. «»Vivir como un cura». Algunas precisiones cuantitativas respecto al imaginario social sobre el clero en el siglo XVIII», en Aranda Pérez, F. J. (Coord.), Sociedad y élites... 101-147, Cuenca.

127 Blanco Díez, A. 1945-1946. «Los deanes de la Catedral de Burgos». Boletín de la Comisión Provincial de Monumentos» 90-94: 546-547. ACC. AC. LR 102. Cabildo del 21 de agosto de 1733, folio 274. El deanato pasa en propiedad a don Bernabé Rubín de Celis, «canónigo y coadjutor de don Pedro Rubín de Noriega, en virtud de Bullas Apostólicas, con futura sucesión en él a dho don Bernabé a causa de hallarse con 64 años de hedad y muchos achaques que le impiden la residencia y ser dho dn Bernabé Pariente mui cercano, sugetto de toda calidad y consideración, graduado de Bachiller y con 18 años de estudios mayores en la Universidad de Valladolid y recibido de Abogado en los Reales Consejos».

Hispania Sacra, LXIV

130, julio-diciembre 2012, 661-719, ISSN: 0018-215X, doi: 10.3989/hs.2012.020 
setenta años de edad y 23 como deán, «viéndose sumamente delicado de salud por la enfermedad de gota que le aquejaba, y que le imposibilitaba cumplir con las cargas de su alta dignidad», solicitó y obtuvo licencia para conferir el Deanato en Coadjutoría. Lo ejecutó su sucesor D. Alfonso (sic) Calderón de la Barca». ${ }^{128}$ Los momentos críticos fueron múltiples y cada vez más próximos. En 1725, 1732, 1734, 1735, 1736, 1737 y 1738, don Bernabé sufrió graves y frecuentes quebrantos en su salud y solicitó el QP por «la necesidad con que se halla de hazer algún exercicio para su recobro». ${ }^{129}$

En agosto, de 1734, habiéndosele concedido anteriormente el PQ el 18 de junio para 2 meses, le acometió un «nuevo accidente de tercianas dobles», patología que aumentaba los sufrimientos de la gota. Esperando mejorar, se trasladó a Valladolid, donde hubo de guardar cama, «medicinándose continuamente». Era un «riguroso enfermo». La debilidad «no le permitía mudar de estación para la convalecencia», circunstancia que, por la lejanía y el vacío real de poder en el Cabildo, enervó las pasiones de los otros capitulares. ${ }^{130}$

${ }^{128}$ Blanco Díez, A. «Los deanes...». Para la relación tío-sobrino en los procedimientos de cesión de prebendas capitulares, véase Benito Aguado, M. T. 2001... 125-128, Peñafiel Ramón, A. 1995. «Iglesia, poder y perpetuación en la España del siglo XVIII: la escuela de niños de Villanueva del Campo», en Hernández Franco, J., Familia y poder. Sistemas de reproducción social en España (siglos XVI al XVIII): 127-138, Murcia, Morgado García, A. 2000. «Vida de canónigo. Percepción, origen y status de vida del alto clero durante el Antiguo Régimen», en Aranda Pérez, F. J. (Coord.): 77-100, Díaz Rodríguez, A. J. 2006. «Entre parientes. Modelos de formación de dinastías familiares en el Cabildo catedralicio cordobés (ss. XVI-XIX)», en Congreso Internacional «Las élites en la Época Moderna: La Monarquía Española»: 255-274, Córdoba, Aldea Vaquero, Q. «Iglesia y Estado en la época del Barroco», en Menéndez Pelayo, R. (Dir.), La España de Felipe IV: tomo 25, 558-633, Madrid, Coronas Vida, L. J. 1986-1987. «Los miembros del Cabildo de la Catedral de Jaén (1700-1737)» Chrónica Nova 15: 105-108 y el 1777. Dictionnaire ecclésiastique et canonique portatit: tomo I, 381-382 y tomo II, 534-537, París y Irigoyen López, A. 2000: 49-91, Cabeza Rodríguez, A. 1996: 252-252 y Vázquez Lesmes, R. 1987: 73.

129 ACC. AC. LR 102. Cabildo del 12 de abril de 1734, folio 494, Cabildo del 16 de junio de 1734, folio 536 y Cabildo del 18 de agosto de 1734, folio 569. Para 1725, ACC. AC. LR 99. Cabildo del 15 de octubre de 1725 , folio 557

130 ACC. AC. LR 102. Cabildo del 18 de agosto de 1734, folio 569. El encargado de diagnosticar, recetar y vigilar los padecimientos del deán fue don Juan Calderón, médico y catedrático de Prima de Medicina de la Universidad de Valladolid. En el maravilloso ACC. Libro 108 del archivo de la Catedral burgalesa disponemos de varias certificaciones del citado doctor. En mayo de 1737, atestiguaba «que le asaltó una irritante destemplanza (...) que precisó a la evacuación de Sangre en los vasos mayores y no haviendo alcanzado mejoría se repitió la Sanguijuela por haverle postrado lo acre del humor inmóvil en la cama y para facilitar la transpiración, dilatación y alivio de tan grabe ocurrencia se le van prosiguiendo diferentes medicamentos» (folio 629). El mal de gota que le afectaba le producía «la fluxión de humores implicados a brazos, codos, rodillas y pies, a cuyo fin habiendo dado principio en el presente mes a usar de los medicamentos lenitivos y purgantes, se prosigue en ellos y ottros apósitos conducentes a la avilitazión de las articulaciones y arterias ocupadas, que le impiden dejar la cama y poder hazer el exercicio que necesita para su restablezimiento». ACC. Libro 108. Certificación del 15 
Las quejas no eran nuevas. En abril de 1734, el deán Rubín, ante «el quebranto que ha padecido en su salud y la necesidad con que se halla de hazer algún exercicio para su recobro», solicitó el PQ, sabedor o no de que existían irregularidades.

«Se trató sobre si se debía conceder o no dho puntto vajo del concepto de quartanario, así por no hallarse des apuntado de enfermo dho Señor como por estar en la primera residencia de su Dignidad». Hechas las averiguaciones pertinentes, se descubren en la jurisprudencia capitular «dos Exemplares de averse concedido el punto de Quartanario a los Sres Arcediano de Burgos y Dn Gabriel de Crispijana no obstante hallarse en primera residencia». Rememoradas las decisiones del 16 de noviembre de 1722, «que trata del modo y circunstancia con que se deben conceder los puntos de Quartanario para evitar los abussos introducidos», la votación, 1 negra y 31 blancas, no dejaba lugar a dudas: el Cabildo aceptaba que, desapuntándose de enfermo, «ussase del referido punto», es decir, de la «baja» a pesar de todo. ${ }^{131}$

En abril de de 1735, Rubín de Celis aún permanecía en Valladolid, pues «estando para ponerse en Camino para esta Ziudad [se refiere a Burgos] le sobrevino el Accidente de Gota y le redujo [de nuevo] a la Cama (...) y en tan penosa inopinada coyuntura recurría a su acreditada piadosa clemencia para que sirbiéndose continuarla». ${ }^{132}$ Sus frecuentes recaídas, su suma debilidad y el sentir de los médicos ${ }^{133}$ le retenían.

El enfado iba en aumento. Para paliar la animadversión hacia él, en una carta, enviada desde Valladolid, el 15 de diciembre de 1736 informaba de que le había sobrevenido «un insulto rehumático elevado a la parte superior de la Cabeza y pecho [promovido el 22 de noviembre], originándose una sofocante destilación al pecho e irritados los humores, y especialmente el de la Gota», imponderables que le ataban «inmóvil a la Cama, para cuio alivio avían aplicado varias mediçinas y proseguía en su curación». ${ }^{134}$

El 7 de enero de 1737 se leyó en Cabildo otra misiva del 30 de diciembre 1736. En ella reiteraba su intención de volver, «aunque fuese accidentado». De hecho, «escasamente convalecido, executó el Viaje por Evitar notiçias opuestas

de junio de 1737, folio 635. Ya en diciembre de 1736 se había encontrado mal de sus patologías, incrementadas «por el rigor de fríos y heladas que han prececido», de forma que le asaltó una «nueva constipación de humores, complicados con el de la gota y algunas obstrucciones». ACC. Libro 108. 18 de enero de 1737, folio 664. Véase León Gómez, P. 2002. «La consulta médica...». Dynamis 22: 279-302.

131 ACC. AC. LR 98, Cabildo del 16 de noviembre de 1722, folio 495.

132 ACC. AC. LR 102, Cabildo del 14 de abril de 1735, folios 703-704.

133 No asumían los galenos la responsabilidad del viaje desde Valladolid a Burgos por ser muy arriesgado, «hallándose con la prohibición de poder salir de casa para ello». Ibídem.

134 ACC. AC. LR 103, Cabildo del 17 de diciembre de 1736, folio 330.

Hispania Sacra, LXIV

130, julio-diciembre 2012, 661-719, ISSN: 0018-215X, doi: 10.3989/hs.2012.020 
a la Realidad». Era consciente de «la notoria publicidad que tiene en aquella Ziudad» su situación personal, su lejanía de la Catedral y de la residencia de sus prebendas. Aunque quebrado y penoso por sus reiteradas patologías, estaba obligado a desvanecer las «conjeturas» que sobre él gravitaban y, por supuesto, las molestias ocasionadas al Cabildo ${ }^{135}$. No todos opinaban igual y así se lo hicieron saber.

En junio de 1737 aún se encontraba, enfermo, en Valladolid, sin «emplearse en servicio del Cavildo que fue siempre su principal Ojeto». ${ }^{136}$ En octubre persistían sus achaques, agravados con una erisipela y la notoria, y permanente, enfermedad de gota. El Cabildo mostraba abiertamente su falta de simpatía, sobre todo, «por [su] ausencia, por no querer o no poder residir y serbir su dignidad» y dejarla en manos de su coadjutor, don Alonso Calderón de la Barca.

Era ya demasiada larga la ausencia. En el Cabildo se planteó si era posible aplicarle con rigor el derecho canónico y las disposiciones del Concilio de Trento. El prolongado alejamiento de Rubín de Celis ponía en tela de juicio, cuando no impugnaba totalmente, «la Causa final y principal motibo de concederse» el punto de quartanario, que era, según sus palabras, «la necesidad de la Iglesia o evidente utilidad de su mayor serbizio y aumento del Culto Divino». En atención a todo ello «eran del parecer dhos Señores no deberse conzeder a dho Señor Bernabé Rubin el punto de quartanario que pide». La irritación fue mayúscula cuando quedó claro que «el Cavildo no tenía facultad alguna en esa razón (...) por cláusula expresa, voluntad y ley con que su Santidad le avía concedido» la «baja». 137

Don Alonso Calderón de la Barca, en 1739, fecha del comienzo de su dignidad como titular, sin coadjutoría, asistió al 100\% de los Cabildos y en los períodos $1739-1747$ y $1752-1754$ y en 1760 a un promedio muy elevado, del $89 \%$ de las llamadas capitulares. En 1748-1751 y 1761-1769 las asistencias rozaron el $60 \%$. Los momentos de absentismo, forzoso o no, más significativos se produjeron en los períodos 1755-1758 -con un promedio de ausencias del 52\%- y los últimos años de su existencia, en 1771-1773, en que las asistencias (18.9\%) superaron abiertamente a las ausencias (81.1\%). Puede verse en el gráfico VII.

135 ACC. AC. LR 103, Cabildo del 7 de enero de 1737, folio 334.

136 ACC. AC. LR 103, Cabildo del 29 de junio de 1737, folio 426.

${ }^{137}$ ACC. AC. LR 103, Cabildo del 3 de octubre de 1738, folio 758. A pesar de todo, el Cabildo burgalés en el momento del óbito de Rubín de Celis, ocurrido el 31 de mayo de 1743 en Valladolid, remitió a su homólogo capitular una Carta en la que le reprochaba no haber asistido a su entierro, lo cual redundaba «en deshonor nuestro y aún de las demás Stas Iglesias el que una Dignidad, canónigo o Racionero de qualquiera de ellas no tubiesse esta honorífica distinción de los demás clérigos». ACC. Libro 110, Carta al Cabildo de Valladolid del 17 de junio de 1743, folio 140. 
GRÁFICO VII ASISTENCIAACABILDOS: DEÁN CALDERON

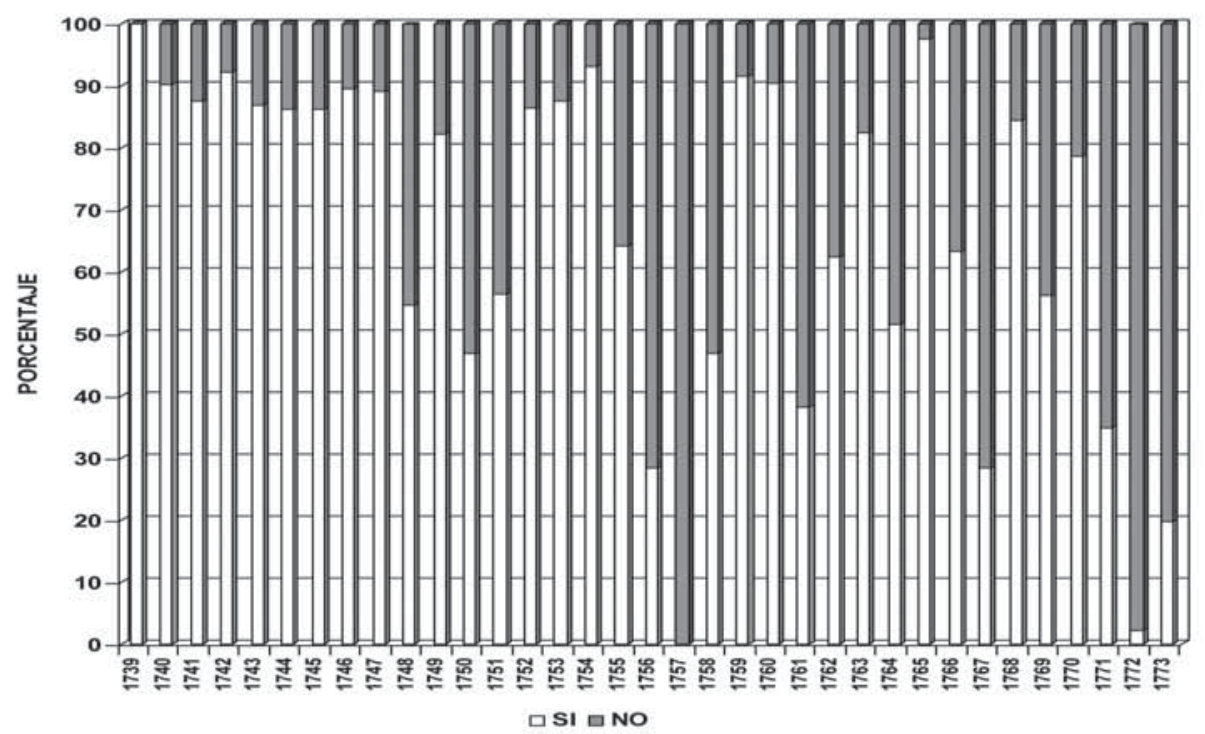

La primera aparición de Calderón de la Barca como deán titular se produjo el 2 de marzo de 1739.138 En agosto de 1748 solicitó, por vez primera, el PQ al sufrir unas «tercianas bastantemente molestas». ${ }^{139}$ En 1751 disponemos de una carta al Cabildo en la que señalaba «no estar restablecido del Quebranto de su Salud», si bien no pidió el PQ. ${ }^{140}$

138 ACC. AC. LR 104, Cabildo del 2 marzo de 1739, folio 4. Algunos hitos esenciales de su existencia en Sanz de la Higuera, F. J. 2002. «»Un capellán que sirve la mesa» y otros menesteres. Burgos a mediados del siglo XVIII». Studia Historica, Historia Moderna 24: 354, Sanz de la Higuera, F. J. 2005. «Cebadas, mulas, caballos, carruajes y habas. La Catedral de Burgos en el Setecientos». Hispania Sacra 116: 581-584 y 588 y Sanz de la Higuera, F. J. 2006.«Seminario de San Nicolás (Burgos, 1743): una rectoría apetecible, un litigio aborrecible». BIFG 232:149-177. Aprovecho estas páginas para reivindicar el buen hacer de Vaquero Lastrés, B. 1986. «La hidalguía en Betanzos en el s. XVIII: La familia y la vivienda». Anuario Brigantino, 9: 60, a quien lamentablemente olvidé citar en el artículo de Studia Historica.

139 ACC. AC. LR 105, Cabildo del 19 de agosto de 1748, folio 667. Todas las habas fueron blancas. Sus «compadres» aún le tenían un gran aprecio y confianza. En 1748 sus asistencias (54.6\%) y sus ausencias $(45.3 \%)$ a los Cabildos estuvieron casi equiparadas. En ese momento rubrica el primer testamento del que tenemos noticia. Su estado de ánimo - «estando de pie aunque con algunos achaques abituales y en mi cabal Juizio»- y los sufrimientos de la enfermedad aconsejaban preparar, con prontitud, el advenimiento de un presunto fallecimiento. Archivo Histórico Provincial de Burgos. Protocolos Notariales (en lo sucesivo AHPB. PN). Francisco de Villafranca. Legajo 7087 (21 de agosto de 1748), folios 212-217.

140 ACC. AC. LR 106, Cabildo del 22 de enero de 1751, folio 267.

Hispania Sacra, LXIV

130, julio-diciembre 2012, 661-719, ISSN: 0018-215X, doi: 10.3989/hs.2012.020 
El siguiente episodio que le obligó a pedir la «baja laboral» se registra en julio de 1761. Los médicos le diagnosticaron «una suma devilidad de caveza y otros síntomas por lo que se ha medicinado». ${ }^{141} \mathrm{El}$ deán Calderón anunciaba a sus «compadres, en junio de 1764, «hallarse enfermo e imposibilitado para la asistencia deel chorro y Dibinos oficios» y solicitaba varias prórrogas «por continuar en la indisposición y la Hipocondría y nezesittar insistir en el paseo y exercicio a oras proporcionadas». ${ }^{142}$ Sus patología comenzaron a ser mucho más graves después del destierro (1766-1767) que hubo de cumplir por sus enfrentamientos con las autoridades borbónicas, tanto eclesiásticas como laicas. ${ }^{143}$ En agosto de 1767, las habas blancas del Cabildo refrendaban las certificaciones de los médicos que le hallaban «con una gran debilidad de Caveza y opresión de Corazón por exaltación del humor hipocondriaco». ${ }^{144}$

A partir de 1769, Calderón de la Barca se debatió habitualmente entre la razón y la sin razón-«en su indisposición aún no se halla la Cabeza recobrada»-, siendo las ausencias el ingrediente esencial, pues faltó en el $81.1 \%$ de los Cabildos celebrados. En septiembre de 1769 los médicos dictaminaron que se hallaba sistemáticamente instalado «en el insulto de la exaltazión de la Melancolía Hypochrondriaca». ${ }^{145}$

En enero de 1770, solicitó del Cabildo el «Punctto de Quartana perpetuo». Basó su petición en que «se halla en edad de 61 años y en la residencia de la misma desde el año de 1738 inclusive», en su trabajo incansable «para evacuar varios encargos que le ocurrieron en la Cortte», siempre con el porvenir del Cabildo en su punto de mira -«en todas ocasiones ha procurado acreditar su Zelo y justo reconocimiento a tales honras como al cumplimiento de su obligación en quanto han alcanzado sus cortas facultades»-, «aunque con grave quebranto de su salud y con algunos [muchos] sinsabores». El Cabildo, a pesar de la suma «debilidad de Cabeza» del deán, se limitó a conservarle el punto de en-

141 ACC. AC. LR 108, Cabildo del 3 de julio de 1761, folio 131. Las habas fueron todas blancas. En 1761 las ausencias (el $61.8 \%$ de los Cabildos no fueron presididos por él) superaron ampliamente a la asistencia $(38.2 \%)$.

${ }^{142}$ ACC. AC. LR 109, Cabildo del 6 junio de 1764, folio 33 y del 6 de julio de 1764, folio 49.

143 Véase Sanz de la Higuera, F. J. 2005. «Cebada, mulas, caballos...» Hispania Sacra 116: 583-584. ACC.AC. LR 110, Cabildo del 6 de marzo de 1767, folio 111.

144 ACC. AC. LR 110, Cabildo del 12 de agosto de 1767, folio 226. En dicho año, las prolongadas ausencias $(71.7 \%)$ laminaron a las presencias $(28.3 \%)$.

145 ACC. AC. LR 111, Cabildo del $1^{\circ}$ de septiembre de 1769, folio 325. Pérez Galdós hilvanó para La Zaína una descripción que le cuadra bien al deán Calderón. «Un mal que nadie conoce ni se ha visto otro parecido, pues unos lo tienen por locura; otros por consunción; éstos, por reumatismo, y aquellos, por melancolía. Lo cierto es que se muere sin remedio y ahora ha dado en llorar, después de dos días en que no ha hecho más que morderse, arrancarse los cabellos e insultar a todos, a mí principalmente, llamándome necio y mentecato». Pérez Galdós, B. 1894. «Napoleón en Chamartín», Obras completas, tomo VIII, Episodios Nacionales: Capitulo XXVI, 454, Madrid. 
fermo y de «Quartanario» sin autorizar, sin embargo, la invalidez absoluta, dado que era «temible [sic] que, si se abriera la puerta, podría experimentarse abuso de la de otros». ${ }^{146}$ Sus achaques persistieron año tras año (1771-1773). ${ }^{147}$

Desde abril de 1773 se encontraba consumido por un «afecto Capital que le imposibilitó salir de Casa todo dho mes». ${ }^{148}$ Los médicos, en agosto, afirmaban que estaba algo recuperado y le encarecían a tomar baños sulfúreos, «de los que no ha podido usar a causa de la inconstancia del tiempo». ${ }^{149}$ En un post-mortem, lamentablemente sin tasaciones para sus enseres domésticos, que efectuó en febrero de 1774 se infirma de sus postreras horas. En noviembre de 1773, 150 «se hallaba agonizando y destituido del uso de sus Sentidos, en fuerza de un accidente de perlesía y apoplejía que le havía acometido fuera de la Casa de su habitación». . $^{151}$

Del abad de San Quirce y canónigo Ramón de Larrínaga hay constancia de sus enfermedades en las Actas capitulares y en buen número de testamentos que rubricó, nada menos que 8 -con mucho el más prolífico de la ciudad-. Véase el grafico VIII.

A grandes rasgos, se observan 4 etapas bien caracterizadas. La fase 17321738 , con un $70.9 \%$ de asistencias. Entre 1739-1754 con un 56.6\% de ausencias. En el período 1755-1760 con una ligera tendencia a no estar ausente, con el 59.2\% de asistencias y, a la postre, en el de 1761-1773, apenas asistió a los Cabildos, con un 76.4\% de ausencias - en concreto, descuellan 1771 (16.3\% de asistencias), 1771 (¡i5.1\%!!) y 1772 (8.6\%). En 1773, Larrínaga Arteaga no pisó la Catedral.

Sus patologías más graves comienzan en agosto de 1734, fecha en la que «avía padezido una Calentura aguda con una especie de Garrotillo que le havia prezisado a medicarse y dejado una molesta destilazión al pecho». ${ }^{152}$ En

146 ACC. AC. LR 111, Cabildo del 19 de enero de 1770, folio 448 y Cabildo del 12 de febrero de 1770, folios 470-471. El 4 de enero de 1770 firmó otras últimas voluntades, a la postre el testamento bajo cuya letra falleció. AHPB. PN. Legajo 7098/2. Francisco de Villafranca (4 de enero de 1770), folios 325-331.

147 ACC. AC. LR 112, Cabildo del 22 de mayo de 1771, folio 68 -las habas todas blancas-, Cabildo del 23 de agosto de 1771, folio 141 y Cabildo del 19 de junio de 1772, folio 299. El deán se encontraba aquejado de su «acostumbrada exaltación de la melancolía hypocondriaca y debilidad consiguiente de Cabeza»-2 habas negras y 10 blancas-.

148 ACC. AC. LR 112, Cabildo del 28 de mayo de 1773, folio 524 y Cabildo del 4 junio de 1773, folio 528. Se le dieron 2 meses de prórroga con 3 habas negras y 16 habas blancas.

149 ACC. AC. LR 112, Cabildo del 9 de agosto de 1773, folio 560.

150 ACC. Libro 39, Posesiones en el Cabildo catedralicio de Burgos: Libro de entradas y salidas de prebendados, folio 6 .

151 ACC. Libro 98 (1773). Abintestato de don Alonso Calderón de la Barca, folios 1009-1035. En 1773, el $80.3 \%$ de los Cabildos se habían celebrado sin su presencia física.

152 ACC. AC. LR 102, Cabildo del 18 de agosto de 1734, folio 570. 


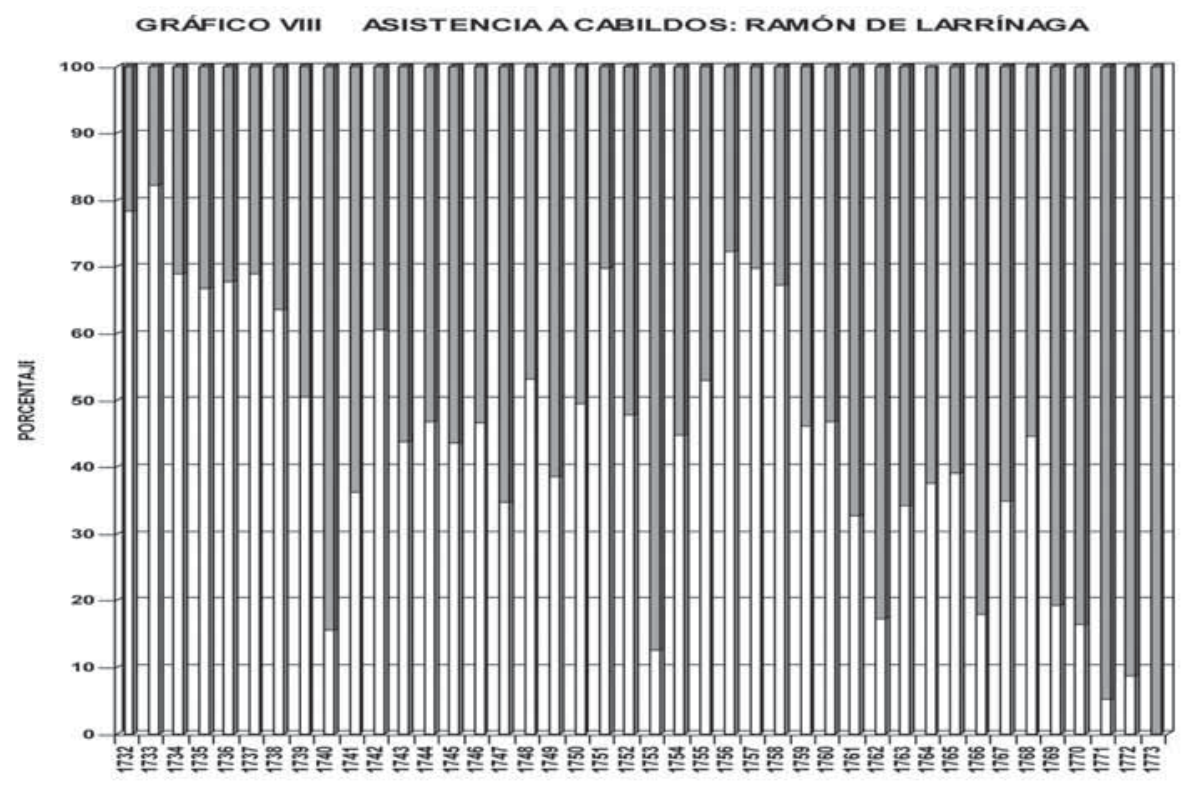

口

abril de 1746 sufrió «una molesta enfermedad que le ha dejado con bastante debilidad», 153 achaque que confirmaba el aparecido en el pasado marzo y para el cual el médico había dispuesto ser imprescindible «tomar algunas medicinas y aguas minerales y a sus tiempos hazer un moderado exercicio».

El doctor Herce, médico del hospital de San Juan, emitió una certificación jurada en la que diagnosticaba los males de don Ramón como «fiebre Reumática conttinua con la durazión de cattorze días», afección que le deterioraba gravemente el hígado. La Catedral, por su «situación sumamente fría y Umeda», era lugar poco recomendable para esta «indisposizión reumática». ${ }^{154}$ Hemos de esperar a febrero de 1766 para una nueva petición de un PQ. Se trata de una «Calentura inflamatoria con otros achaques habituales». ${ }^{155}$ La secuencia de los días que estuvo enfermo se recoge en el gráfico IX.

153 ACC. AC. LR 105, Cabildo del 31 de abril de 1746, folio 384.

154 ACC. AC. LR 108, Cabildo del 30 de marzo de 1746, folios 329-330. En 1747 comenzó el maratoniano rubricar testamentos de don Ramón, en muchos casos redactados al hilo del agravamiento de sus enfermedades. AHPB. PN. Jacinto del Río. Legajo 7053/1 (6 de mayo de 1747), folios 68-69 y Jacinto del Río. Legajo 7053/1 (17 de julio de 1748), folios 405-406.

155 ACC. AC. LR 109, Cabildo del 5 de febrero de 1766, folio 379. Previamente había emitido otros testamentos en marzo de 1761 - AHPB. PN. Bernardo Alonso de Illera. Legajo 7188 (20 de marzo de 1761), folios 513-517 y en noviembre de 1763 - AHPB. PN. Bernardo Alonso de Illera. Legajo 7189. 
El 11 de mayo de 1770 solicitó la «baja». Los médicos atestiguaban que Larrínaga padecía «habitualmente, de más de 15 años a esta parte, los accidentes de rheuma artrítico y [mal de] piedra, cuia expulsión le ha puesto en dos ocasiones en grave estrecho y espezialmente el año 66. Como este accidente es incurable radicalmente y sólo puede solicitarse la precauzión de más frecuentes insultos», aconsejaba «exercicio moderado en el campo a horas cómodas» y el alejamiento de la intemperie de la Catedral, en la que por mucho carbón y leña que se consumiese siempre hacía bastante frío y humedad. Don Ramón podría sufrir «un afecto mortal».156

Los años más aciagos fueron 1772 y 1773 , dejando a parte el momento de la muerte de su madre, cuando contaba con 4 años de edad. En octubre de 1772 fue sangrado repetidas veces «a causa de haverse exaltado el humor herpético que habitualmente le molesta, de cuya resulta ha quedado con mayor carga y debilidad en las piernas». ${ }^{157}$ Entre septiembre y diciembre de 1773 tuvo un gradual deterioro de su salud, que acabó en su muerte. Procuraba por todos los medios «esforzarse por residir su Coro, le ha sido imposible, aún en el verano del presente año, a causa de las herpes que tiene en ambas piernas y provenirle una suma debilidad que no le permite andar sólo». Que existía un «inminente peligro» lo pone de manifiesto que tres meses después falleció. ${ }^{158}$

Los canónigos Carrera y Haedo buscaron el PQ perpetuo. Sus afecciones les incapacitaban para cumplir sus obligaciones capitulares.

Felipe Carrera presenta un ritmo de asistencia dividido en dos etapas bien definidas. La de 1744-1754, su asistencia rozaba el 60\%. En de 1755-1770, hay solo un $2.9 \%$ de asistencias a los Cabildos, como puede verse en el gráfico X.

En su etapa como coadjutor de la canonjía que comenzó a ocupar como titular a partir de 1744, Felipe Carrera sufrió, entre junio y octubre de 1733, dos afecciones diferentes. En junio, se hallaba «sumamente debilitado y con un dolor vehemente en el pecho y espalda, resulta de una peligrosa enfermedad que

(23 de noviembre de 1763), folios 199-202. Véanse Sanz de la Higuera, F. J. 2006. «La temible f(r)actura de la muerte. Fallecer en el Burgos del Setecientos». Cuadernos de Investigación Histórica 23: 251-283 y Sanz de la Higuera, F. J. 2007.«Aristocracia eclesial «en carrera de salbación». Las dignidades catedralicias burgalesas entre la vida y la muerte a mediados del Setecientos». Cuadernos de Investigación Histórica 24: 355-413.

${ }_{156}$ ACC. AC. LR 111, Cabildo del 11 de mayo de 1770, folio 534.

${ }^{157}$ ACC. AC. LR 112, Cabildo del 5 de octubre de 1772, folios 371-372. En noviembre persistían los problemas - ACC. AC. LR 112, Cabildo del 9 de noviembre de 1772, folio 451. Desde su jubilación en octubre de 1761, tras 30 años de servicios - ACC. AC. LR 108, Cabildo del 9 de octubre de 1761, folio 189 -, don Ramón asistió bastante poco al coro catedralicio.

158 ACC. AC. LR 112, Cabildo del 24 de septiembre de 1773, folio 580-581. El anuncio de su óbito llegó al Cabildo el 10 de diciembre - ACC. AC. LR 113, Cabildo del 10 de diciembre de 1773, folios 2-3. 
GRÁFICO IX. DIAS DE ENFERMO. RAMÓN DE LARRÍNAGA

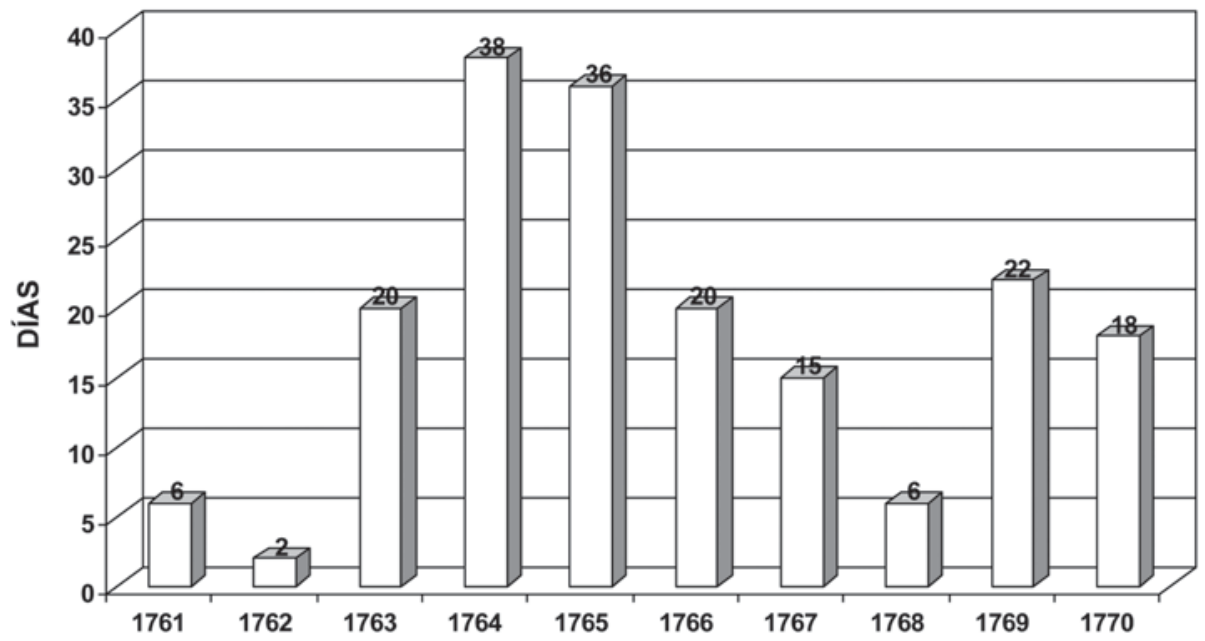

GRAFICO X. ASISTENCIA A CABILDOS: CANONIGO CARRERA

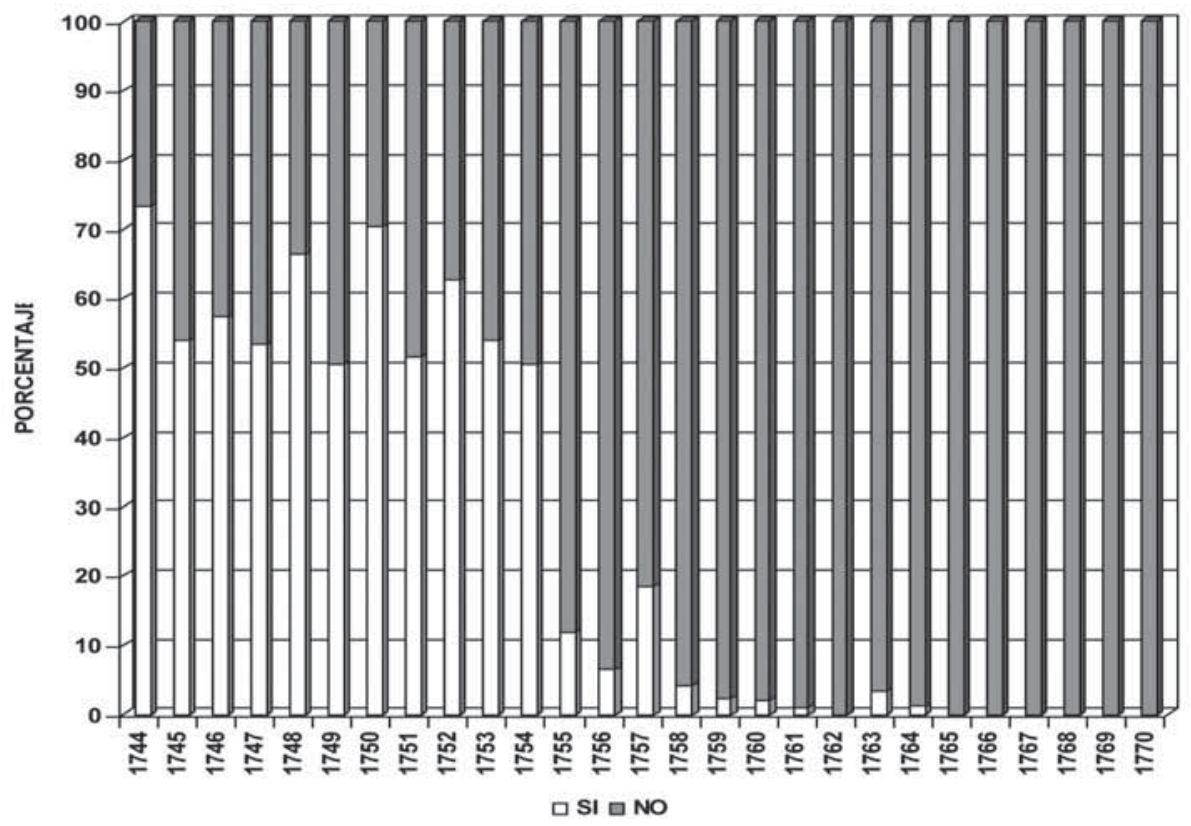


padeció en la villa de Madrid». ${ }^{159}$ En octubre, quizá como consecuencia de la debilidad que arrastraba, contrajo «unas perniziosas tercianas». ${ }^{160} \mathrm{Su}$ salud no fue nunca excesivamente buena. En abril de 1754, exponía ante el Cabildo «averse hallado enfermo dilatado tiempo». ${ }^{161}$ Esa patología es, sin duda, una «grave enfermedad de Reomatismo, la que le ha dejado Vastantte debilita$d o » 162$ y que se encuentra en la base de la consecución del PQ perpetuo que el Cabildo se concede, atentos los capitulares a la «ymposibilidad de acudir a la Iglesia [por sus disfunciones corporales] y en attenzión a ttener Quarentta años de Iglesia [léase residencia] y allarse en hedad abanzada como la de Settentta años». El PQ perpetuo se le otorgaba «sin limitación de tiempo a Claustro deel Cavildo y asistiendo a aquellas oras que pueda, según le dicte su concienzia sin perjuizio de Su Salud». ${ }^{163}$

A partir de septiembre de 1763, y hasta su fallecimiento, ${ }^{164}$ todas las anotaciones están sesgadas exclusivamente por sus afecciones reumáticas persistentes. Los médicos exponían en sus certificaciones juradas que no se acreditaba «haber Nobedad Expecial en sus habituales Dolencias» o que continuaba «con la misma enfermedad pero mucho más agravada a Causa de que desde el próximo mes de Noviembre [1763] ha sufrido tres Recios insultos que le han deteriorado enormente, especialmente el último del que aún Combaleze». ${ }^{165}$

Diego Haedo tuvo reuma y artritis, pero no consiguió el PQ perpetuo. También en su trayectoria hay cuatro etapas, como puede verse en el cuatro XI. Una primera, 1744-1751, con un promedio de asistencia muy notable, el $73.7 \%$. Una segunda, 1752-1762, en el que las ausencias se dispararon de manera rotunda, en especial en los años 1755 y 1761. Una tercera, 1763-1770, en que las asistencias llegan al 68.3\%. Finalmente, una cuarta, 1771-1780, sobre todo a partir de 1772 , en su asistencia es de $3.1 \%$.

159 ACC. AC. LR 102, Cabildo del 5 de junio de 1733, folio 207. Don Felipe Carrera actuó como lugarteniente de su cuñado, don Pedro Tomé González, administrador general de la Santa Cruzada de la ciudad y del Arzobispado, excepcional empresario lanero y miembro, prior y cónsul del Consulado de Burgos, en múltiples gestiones realizadas, por su mandato, en La Corte, en especial con don Juan de Lastiri, administrador general de dicha gracia, en marzo de 1733. Véase Sanz de la Higuera, F. J. 2003.«Pólvoras, municiones, lanas, granos, bulas y papel sellado (1704-1764). Don Pedro Tomé González y la hora Navarra en el Burgos del siglo XVIII». BIFG 227: 405 (375-411).

160 ACC. AC. LR 102, Cabildo del 16 de octubre de 1733, folio 324.

161 ACC. AC. LR 106, Cabildo del 11 de abril de 1754, folio 825.

162 ACC. AC. LR 106, Cabildo del 11 de agosto de 1755, folio 885. Las habas en todo momento fueron para Felipe Carrera todas blancas.

163 ACC. AC. LR 108, Cabildo del 22 de junio de 1761, folio 124.

164 Archivo Diocesano de Burgos (ADB). San Martín. Libro de difuntos. $1^{\circ}$ de agosto de 1770. Para Felipe Carrera no disponemos de testamentos ni inventario post-mortem.

165 ACC. AC. LR 109, Cabildo del 25 de mayo de 1764, folio 26.

Hispania Sacra, LXIV

130, julio-diciembre 2012, 661-719, ISSN: 0018-215X, doi: 10.3989/hs.2012.020 


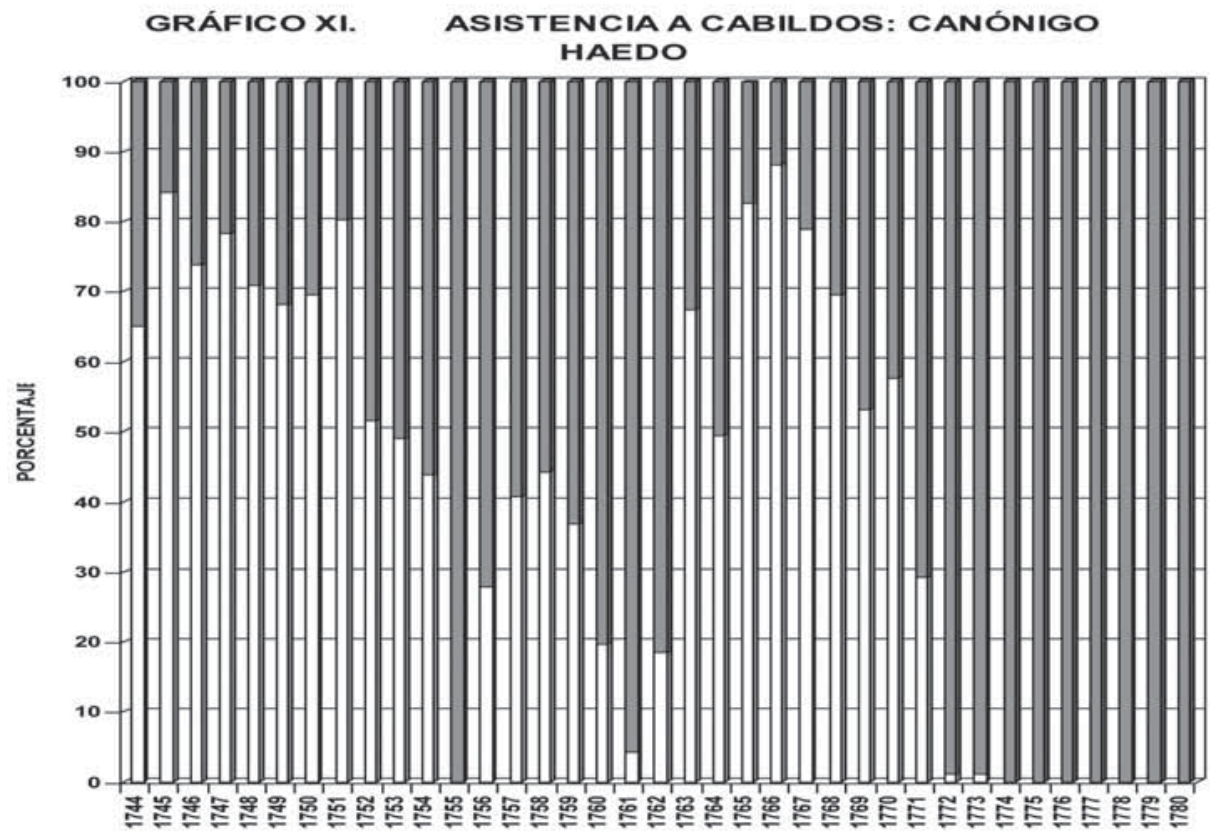

모 a NO

Sus patologías comenzaron en noviembre de 1740. Una «fiebre continua accesional que le sobre Vino a unas tercianas» le obligaron a pedir la «baja laboral». ${ }^{166}$ En septiembre de 1748 hubo de luchar, de nuevo, contra una «tercianas malignas que le han dejado con bastante debilidad». ${ }^{167}$ En noviembre aún estaba profundamente aquejado por la enfermedad, que marcó el resto de su existencia. Señalaba el médico que «se halla actualmente medicinado de una fiebre Continua Ascensional que le sobre Vino a unas tercianas». De resultas de ello, Haedo puso en conocimiento de sus «compadres» capitulares que se encontraba en disposición «de no poder salir de Casa a Causa de unos dolores reumáticos que me an aCometido».168

En 1768 reaparece pidiendo la «baja laboral». En enero, y «atenzión a el accidente reumático que ha padecido» se le incrementó el habitual «abszeso reumático que le acometió a la garganta de el pie izquierdo, su empeine y dedo grueso, causándole bastante elevazión tumorosa». Los médicos prescribieron

166 ACC. AC. LR 108, Cabildo del 7 de noviembre de 1740, folio 227.

${ }^{167}$ ACC. AC. LR 195, Cabildo del 7 de septiembre de 1748, folio 687. Todas blancas.

168 ACC. AC. LR 108, Cabildo del 7 de noviembre de 1748, folio 227. 
que se abstuviera de la residencia, «porque la rígida estazión del Ymbierno y espezialmente lo destemplado del frío de la Iglesia puede causarle alguna recaída de la parte afecta».169

A partir de noviembre de 1771, y por causa del frío habido en la Catedral, Haedo vio incrementarse sus sufrimientos. Los médicos denunciaron «un edema erisipilatoso en la pierna derecha, complicada con dolores Artétricos [sic] en la rodilla y tarso, que estos le impiden andar». ${ }^{170}$ En julio de 1772 quedó impedido «el movimiento de medio Cuerpo abaxo, con dolores intensos, espezialmente quando era necesario poner en movimiento las articulaciones». ${ }^{171}$

Entre 1773-1778 se extendió el «afecto Artético [sic]» a gran parte del cuerpo. José Monleón, cirujano del hospital de Barrantes 172 lo trató y, en abril de 1773, «empezó por las segundas falanges de primero y segundo dedo de la mano derecha y se extendió a los restantes dedos como también al metacarpio y carpo, participándose los Dolores del cúbito y húmero». ${ }^{173}$ Sus complicaciones persistieron en octubre de 1773 , febrero, julio, septiembre, hasta verse absolutamente «imposibilitado a poder por si ponerse en pie»-y octubre«... para subir y vajar las escaleras necesita valerse de un Criado que lo lleve...», dado que «prosigue en el impedimento de Piernas y oy nuevamente le ha caído la reuma a la mano derecha y causado una dolorosa inchazón»-y diciembre de $1774-.{ }^{174} \mathrm{Al}$ reuma y a la artritis, en mayo de 1775 , se añadieron los pesares proporcionados por una «indisposición podágrica». ${ }^{175}$

169 ACC. AC. LR 110. Cabildo del 8 de enero de 1768, folios 359-361. Las habas, 4 negras y 16 blancas, nos advierten de animadversiones profundas en el seno del Cabildo -folio 366-.

170 ACC. AC. LR 112. Cabildo del 29 de noviembre de 1771, folio 198

${ }^{171}$ ACC. AC. LR 112. Cabildo del 17 de Julio de 1772, folio 315. Los médicos indicaron como imprescindible librarse de la frialdad o frescura de la Catedral, hacer ejercicio a caballo en los días en los que lo permita el tiempo y que «pase a tomar los aires de su País [Santander], logrando la benignidad de aquel Clima», que logrará «la esterminazión total o a lo menos muchísimo alivio en su accidente».

172 Véase Sanz de la Higuera, F. J. 2005. «Obras en Barrantes (1747-1750)». BIFG 230: 115-147.

173 ACC. AC. LR 112, Cabildo del 19 de abril de 1773, folio 503. Era preciso, para intentar una mejoría aceptable y sostenible, realizar «exercicio en Coche, por no haverle permitido la estación fría del tiempo el de a Caballo». Véase Sanz de la Higuera, F. J. 2004. «Una estancia doméstica que se mueve. Entre las calles y las casas de Burgos a mediados del XVIII». Cuadernos de Investigación Histórica 21: 469-506. Diego Haedo era poseedor de un carruaje y formaba parte del exclusivo club de aristócratas que disponían de forlones, berlinas y carrozas entre sus enseres, circunstancia que obligaba a contratar un cochero - véase 503 -.

174 Para octubre de 1773, ACC. AC. LR 112, Cabildo del 25 de octubre de 1773, folios 606-607. Para febrero de 1774, ACC. AC. LR 112, Cabildo del 28 de febrero de 1774, folio. Para julio de 1774, ACC. AC. LR 112, Cabildo del 18 de julio de 1774, folios 123-124. Para septiembre de 1774, ACC. AC. LR 112, Cabildo del 2 de septiembre de 1774, folio 153. Para octubre de 1774, ACC. AC. LR 112, Cabildo del 21 de octubre de 1774, folios 183-184 y para diciembre de dicho año, ACC. AC. LR 113, Cabildo del 19 de diciembre de 1774 , folio 226.

175 ACC. AC. LR 113, Cabildo del 3 de abril de 1775, folio 303.

Hispania Sacra, LXIV

130, julio-diciembre 2012, 661-719, ISSN: 0018-215X, doi: 10.3989/hs.2012.020 
En mayo de 1775, pidió la jubilación, alegando estar «levantando las cargas de su Prebenda» por más de 30 años. ${ }^{176} 1776$ no mejoró, pues, se anota, que «se halla dho Señor habitualmente imposibilitado y sin curación de los efectos de sus piernas». A sus 74 años se le intentó obsequiar por parte de algunos capitulares con la posibilidad de apuntar el PQ para «la presente Prebenda y sus distribuciones quotidianas como se ha servido executar con otros Yndividuos del Cavildo en iguales términos por obviar el molestar su paciencia con doze memoriales al año». Las habas dijeron que no a «la tal concesión por un año y por Seis meses, y en la tercera que se repartieron parecieron 6 negras y 8 blancas, con que por ser estas más quedó acordado concedersele por quatro meses y con la calidad de que cada Quadrimestre la pida presentando Zertificación de facultatibo que acredite subsistir la expresada imposibilidad». ${ }^{177}$

Haedo, incurable en su enfermedad y «con una total debilidad en los nervios de las piernas», pasó todo el invierno recluido en casa, sin poder salir de la cama, 178 «donde actualmente se halla y aún en Verano». ${ }^{179}$ En agosto de 1779 resolvió, y así se lo comunicó a sus «colegas», que se marchaba «a su País, cuyo Clima benigno le sería muy conduzente a su Salud, al paso que le hera muy perjudizial el rígido y destemplado desta Ciudad [Burgos]». 180 El 28 de marzo de 1780, a las 9 de la mañana, falleció, sin testar, en Ampuero (Santander). ${ }^{181}$

Las patologías de dos canónigos y un racionero de la Catedral sirven de contrapunto a las citadas anteriormente, por su carácter excepcional y no estar exentas de cierto regusto cínico, anecdótico y peripatético.

Miguel Jerónimo Méndez se hallaba, el 24 de septiembre de 1782, «gravemente accidentado desde las ocho de la tarde del día antes (...) según el accidente de emiplexia que le havía acometido». Un criado de la Catedral, que le conocía bien por «haver asistido en diferentes ocasiones en la Casa de dho Señor», le vio «manejar cantidades de Dinero en oro, poniéndolo en varios para-

176 ACC. AC. LR 113, Cabildo del 8 de mayo de 1775, folio 328, Cabildo del 19 de mayo de 1775 , folio 337 y Cabildo del 26 de mayo de 1775, folios 343-344. Todas las habas fueron blancas.

177 ACC. AC. LR 113, Cabildo del 5 de junio de 1776, folio 648.

178 Véase Sanz de la Higuera, F. J. 2009. «Pajas, catres, cujas, camas, ... El lecho cotidiano en el Antiguo Régimen. Burgos (1740-1780)». Cuadernos de Investigación Histórica 26: 435-499.

179 ACC. AC. LR 114, Cabildo del 19 de febrero de 1775, folio 455. «... quando ha salido no ha podido moverse en Casa con las muletas sin una Persona que le sirva de alivio y para vajar las Escaleras se ha valido de Hombres...».

180 ACC. AC. LR 115, Cabildo del 23 de agosto de 1779, folios 326-327.

181 ACC. AC. LC 115, Cabildo del 31 de marzo de 1780, folio 481 . El 15 de abril de 1780 nos topamos con un «testamento: La partte de su Señoría el Deán y Cabildo desta Sta Iga por el Sor dn Diego de Haedo, Canónigo que fue de ella», merced a la potestad y «Costumbre inmemorial» del Cabildo de redactar la «últtima y postrimera Voluntad» de sus componentes. AHPB. PN. Alonso de Melo Peña. Legajo 7215 (15 de abril de 1780), folios 180-181. 
jes no seguros, exponiéndose a que igualmente que él lo huviese visto alguna otra Persona y lo pudiese extraher en la ocasión presente». ${ }^{182}$

El cirujano José Victoriano Gómez, titular del Cabildo y del hospital de Barrantes, «en la noche de el día Veinte y tres al Veinte y quatro (...) [fue] llamado para visitar al (...) Canónigo, a quién allé sobre su Cama medio vestido y enteramente postrado de todos sus miembros y con privación de los sentidos, pues, aunque movía la caveza, abría los ojos, sacaba frequentemente la lengua y vibrava el brazo y Pierna derecha, era todo en fuerza de movimientos espasmódicos que le ocasionaba una Emiplexia en que estaba Constituido, en cuia situación pasó la noche». ${ }^{183}$ El dictamen clínico se completaba con las apreciaciones del médico Pablo de las Heras, titular de la Ciudad, quien también lo encontró «perdido el Juicio y con basttante embarazo en la pronunciación, resultta todo [señalaba el galeno] (...) de un accidente epiléctico que le había acomettido la noche anterior». ${ }^{184}$

Méndez el año anterior había asistido, perplejo y asombrado, primero, amargado y encolerizado, después, a un dramático pleito en el que una de sus criadas le demandó ante la justicia por un presunto impago de salarios, la ridiculez de 165 1/2 reales, que catapultaron al capitular al oprobio público y judicial ${ }^{185}$. La ira que esto le produjo acabó pasándole factura. ¿Qué le hubiese costado abonar el mísero salario de la criada a quien tenía escondidos en las papeleras de su vivienda más de 57.000 reales? ${ }^{186}$ Aunque finalmente Méndez se restableció «perfectamente a su antiguo estado de salud», 187 el Cabildo y algunos de sus miembros quedaron en evidencia ante la opinión pública. ${ }^{188}$

La «abanzada edad y accidentes que ha padecido» habían dejado al canónigo Alonso Carrillo y Acuña «sin [las] facultades correspondientes ni para cui-

182 ACC. Libro 133, folios 530-549 (1782).

183 ACC. Libro 133, folio 331 (24 de septiembre de 1782).

184 ACC. Libro 133, folio 331 (24 de septiembre de 1782).

${ }^{185}$ En palabras del profesor Marcos Martín, siempre sagaz y ecuánime, «una sociedad pleiteadora» que resolvía con litigios, a veces absurdos pero mayúsculamente costosos, todos los flecos de la existencia material. Véase Marcos Martín, A. 2000. España en los siglos XVI, XVII y XVIII: Economía y sociedad: 312-313, Barcelona. El pleito en ACC. Libro 135, folios 1-113 (1781).

${ }^{186} \mathrm{La}$ descripción del dinero acumulado secretamente por el canónigo en ACC. Libro 133, folios 536-543. Véanse las reflexiones de Álvarez Santaló, L. C. 2000: 101-147 y Sanz de la Higuera, F. J. 2002. «Familia, hogar y vivienda en Burgos a mediados del siglo XVIII. Entre cuatro paredes, compartiendo armarios, camas, mesas y manteles». Investigaciones Históricas 22: 207-210.

187 ACC. Libro 133, folio 539 (7 de octubre de 1782).

188 Véase los trabajos editados en el VI Simposio de Historia de las mentalidades «Casa, vecindario y cultura en el siglo XVIII», 1998, entre los cuales descuellan Lozano Armendares, T. 1998.«Y es de pública voz y fama». Conflictos entre vecinos en el siglo XVIII»: 117-130 y Enciso Rojas, D. 1998. «Y dijo que lo conoce de vista, trato y comunicación». Vigilar para denunciar»: 131-142.

Hispania Sacra, LXIV

130, julio-diciembre 2012, 661-719, ISSN: 0018-215X, doi: 10.3989/hs.2012.020 
dar de si ni de la asistencia que le es indispensable en su Casa». ${ }^{189}$ ¿Qué estaba obligado el Cabildo a proveer? Los jueces capitulares pidieron informes a los médicos y cirujanos que les atendían, Félix Antón y José Victoriano Gómez, quienes, en resumen, diagnosticaron «una abolición summa, nacida de la debilidad del celebro [sic] y torpeza de espíritu, familiar a su edad decrépita, a que puede haver aiudado alguna diathesis Melancólica contrahida por la misma tristeza que, según el informe de sus familiares, le ha dominado después de la muerte de su sobrino Antonio Carrillo». ${ }^{190}$

Ante la imposibilidad de cuidar de sí mismo, de su casa y de sus bienes, el Cabildo determinó que, «atendiendo al decoro, que es tan debido a Sujeto de sus circunstancias», la persona más cercana, su sobrina carnal doña Manuela, se asistiría con el esmero y el cuidado que merece. ${ }^{191}$ Pasmados se quedaron los capitulares cuando, a través de una carta elevada al Cabildo, la susodicha les decía que «por la distancia y sitio en que havita e inclemencia de los tiempos, particularmente en Invierno, no le era posible Cuidar de su tío ni tomar a su cargo el manejo de su Casa». ${ }^{192}$

Esta negativa obligó a los capitulares a gestionar sus intereses económicos y el cuidado de su persona. ${ }^{193}$ El canónigo Alonso Carrillo falleció el 6 de diciembre de $1779 .{ }^{194}$

Antonio de Diego ejemplifica las afecciones sufridas por un racionero y músico que, lejos de las «quartanas», tendrá en las ulceraciones de sus extremidades inferiores su más grave padecimiento. Su calvario comenzó en diciembre de 1775 cuando ya era evidente que «el edema que padece a las Piernas aunque habitual en el día le impide el libre movimiento con dolor, para cuyo alivio le ha ordenado la quietud de la Cama».195

El problema se complicó extraordinariamente y, en julio de 1976, el cirujano Victoriano Gómez señalaba que padecía «una úlcera virulenta en ambas piernas con grave inchazón edematoso acre en ellas, acompañada de fuerte esco-

\footnotetext{
189 ACC. Libro 112, 11 de octubre de 1779, folio 700.

190 ACC. Libro 112, 11 de octubre de 1779, folio 701-702. El cirujano aunaba en su certificación sus padecimientos más graves: «abolición de memoria», «manía melancólica»y «divilidad decrépita de su celebro», es decir, lo que hoy llamaríamos demencia senil.

191 ACC. Libro 112, 13 de octubre de 1779, folio 704.

192 ACC. Libro 112, 13 de octubre de 1779, folio 706.

193 ACC. Libro 112, 23 de octubre de 1779, folios 708-709.

194 ACC. Libro 112, 6 de diciembre de 1779, folio 709. El 27 de enero de 1779 rubricó su tercer y último testamento, «estando como estoy bueno, empie aunque con bastantes achaques por mi Abanzada hedad y con mi Sano Juicio y entendimiento natural». La heredera universal de todos sus bienes fue su escurridiza sobrina - AHPB. PN. Alonso de Melo Peña. Legajo 7214 (27 de enero de 1779), folios 60-63.

195 ACC. AC. LR 113, Cabildo del 22 de diciembre de 1775, folio 522.
} 
zor y dolor». ${ }^{196}$ En octubre de 1779, el médico Pablo de las Heras le animaba a tomar la «baja laboral» para «convalecer de la fiebre de grave riesgo con unos dolores reumáticos lumbagos que aún no se ha quitado del todo», afección que le sumió en una notoria debilidad y que se le había extendido a los brazos, patología «mui propia de la estación fría nebulosa». ${ }^{197}$

Para finalizar, unos breves apuntes sobre el diferente grado de incidencia de la «baja laboral» entre los capitulares según fuera su rango. ${ }^{198}$ En 1751, los canónigos y los medio racioneros eran los más propensos a solicitar y disfrutar de la «baja laboral» hasta el punto de que 8 de cada 10 recurrió al PQ para huir de la intemperie de la Catedral. Las dignidades se encontraban a medio camino entre éstos y los racioneros, que era el colectivo catedralicio mejor dotado, aparentemente, de salud. Visto desde la óptica de cuántos «Puncttos de Quartanario» suplicaban los componentes del Cabildo, hallamos que eran los más humildes, es decir, los medio racioneros, racioneros y sochantres -en otras palabras, los músicos y «proletarios» capitulares- quienes en menor medida exigían de su «empresa» la «baja laboral», 199 mientras la aristocracia clerical, dignidades y canónigos, acumulaban múltiples solicitudes y en muchas ocasiones. Eran los privilegios del poder, el rango y la apariencia. ${ }^{200}$ Pueden verse los gráficos XII y XIII.

196 ACC. AC. LR 114, Cabildo del 29 de julio de 1776, folio 25. En ACC. AC. LR 114, Cabildo del 22 de septiembre de 1777, folio 340, seguía con los mismos síntomas y padecimientos.

197 ACC. AC. LR 115, Cabildo del 1 de octubre de 1779, folio 353 y del 17 de enero de 1780, folio 426. En julio de 1780 persistía en «sus antiguos dolores y llagas de las piernas» lo que obligó a concederle a partir de ese momento 24 prórrogas (entre el 31 de julio de 1780 y el 2 de agosto de 1782).

198 Tomo el año 1751 como modelo de trabajo dado que es el año en que, merced a confección del Catastro de Ensenada, dispongo de un censo completo de los componentes del Cabildo catedralicio.

199 Una excepción paradójica es que los medio-racioneros acumularan, sin embargo, el porcentaje de PQ superior a 15 más elevado, dado que el $11.1 \%$ de ellos se encontraba en dicha tesitura.

200 Aunque son muchos, y muy buenos, los trabajos sobre tipos de clérigos en la España del Antiguo Régimen, recomiendo la lectura de Bravo Lozano, J. 2005.«Cura rico/cura pobre. Notas sobre rentas eclesiásticas en el Madrid de fines del siglo XVII», en Suárez Grimón, V., Lobo Cabrera, M. y Martínez Ruiz, E. (Coords.), Iglesia y sociedad en el Antiguo Régimen, Actas de la III Reunión Científica de Historia Moderna de la Asociación Española de Historia Moderna: vol. 1, 129-140, Las Palmas de Gran Canaria.

Hispania Sacra, LXIV

130, julio-diciembre 2012, 661-719, ISSN: 0018-215X, doi: 10.3989/hs.2012.020 
GRÁFICO XII. CAPITULARES (1751) CON ALGUNA BAJA

LABORAL

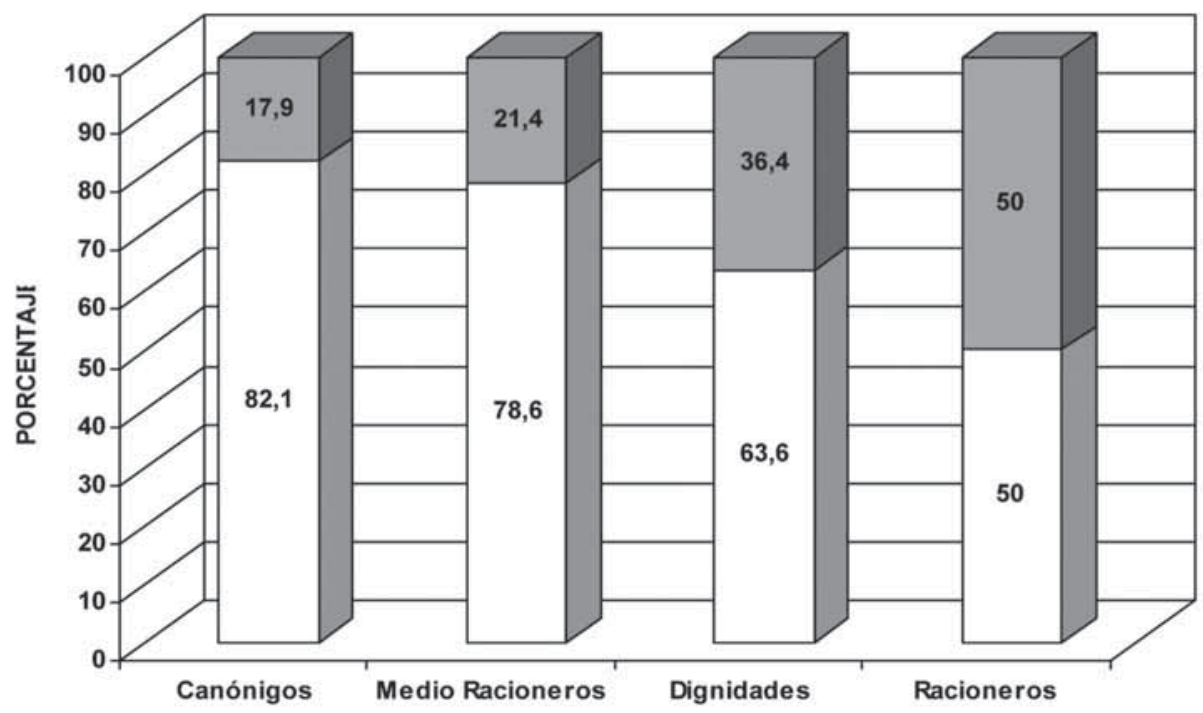

$\square$ SI NO

GRÁFICO XIII. BAJA LABORAL: CATEDRAL BURGOS (1730-1799)

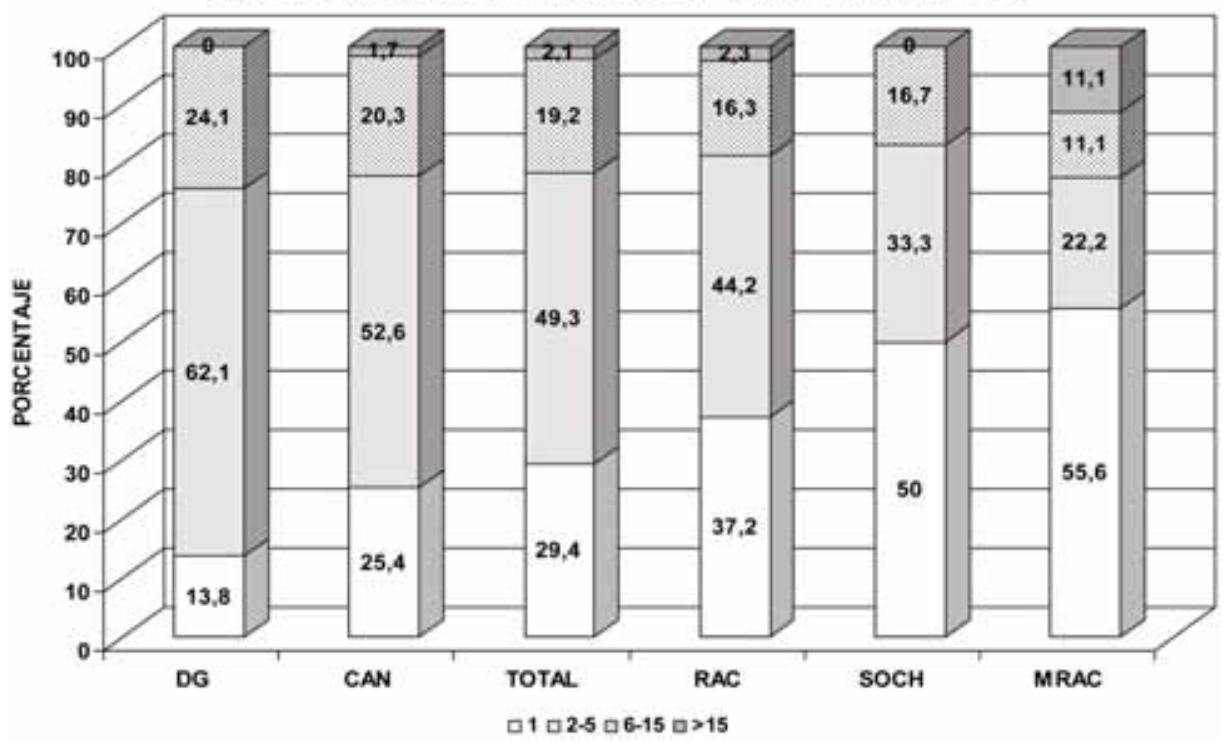

Hispania Sacra, LXIV

130, julio-diciembre 2012, 661-719, ISSN: 0018-215X, doi: 10.3989/hs.2012.020 
A MODO DE CONCLUSIÓN.

Se quedan fuera temas como un tratamiento pormenorizado de las terapias recomendadas por los profesionales de la salud en el Burgos del Setecientos o el seguimiento del ritmo estacional de las «bajas laborales» de los capitulares y las peculiaridades que adoptaban los «Puncttos de Quarttanario» según se tratara de «quartanas», «tercianas» u otras afecciones.

Los clérigos, los privilegiados en general, estaban aquejados de enfermedades que afectaban, tanto en morbilidad como en mortalidad, de una forma diferencial, a las «clases» sociales de mayor alcurnia. ${ }^{201}$

Queda demostrado, de manera argumental, documental y cuantitativa, que el clero catedralicio disfrutaba de privilegios tan «modernos» como la asistencia por un médico de cabecera -galeno titular del Cabildo- y de la existencia del «Punctto de enfermo» 202 y del «Punctto de Quartanario», ${ }^{203}$ derechos que ni siquiera los médicos que les atendían, de manera tan privativa y exclusivista, gozaban en la práctica. La enfermedad dispensaba forzosamente de trabajar al estado llano y pechero pero no abonaba salarios ni generaba ganancias para mantener el hogar sino todo lo contrario. Los gastos en médicos, boticarios, sangradores y medicinas se comían, literalmente, gran parte del nivel de fortuna de muchos vecinos. ${ }^{204}$

La mayoría de la población estaba supeditada a condiciones de vida ajenas a la de los miembros de los Cabildos catedralicios o parroquiales, pues se encuentran fórmulas de «baja laboral» similares en, por ejemplo, la parroquial de San Lesmes, donde el 6 de enero de 1760 aparece la siguiente anotación en sus Actas: «... en el nombramiento de oficios para el buen régimen y gobierno, entre otras cosas propuso el Sr. Dn Francisco Santamaría, Prior, como al Sr Dn Esteban Pasqual, beneficiado más antiguo, atendiendo a su abanzada hedad, la suma asistencia que siempre ha tenido, se le relebase de la Semanería en lo cantado, a cuia propuesta respondieron todos los Indibiduos consentían gustosos, nemime discrepante ...». ${ }^{205} \mathrm{La}$ «mancha de aceite» de la «baja laboral» se

201 Véase Fernández García, A. 1991. «La enfermedad como indicador social. Consideraciones metodológicas», en Castillo, S. (Coord.), La historia social en España. Actualidad y perspectivas: 401428, Madrid, Peter, J. P. 1972 : 135-170 y Perrenoud, A. 1975. «L'inégalité sociale devant la mort a Genève au XVIIe siècle». Population (French Edition) 30: 221-243.

202 Para justificar la ausencia a sus puestos de trabajo de forma puntual, con afecciones de pocos días, era imprescindible apuntarse o desapuntarse de enfermo para lograr el PQ.

203 Procedimiento por el que, para restablecerse de graves y prolongadas enfermedades, se ausentaban por períodos de 15 días ó 1, 2 ó más meses, asegurándose la percepción completa de sus prebendas.

204 Sanz de la Higuera, F. J. 2006: 251-283.

205 Archivo Diocesano de Burgos (ADB). San Lesmes. Libro de Actas del Cabildo. Legajo 39/5. Cabildo del 6 de enero de 1770 , folio 3 .

Hispania Sacra, LXIV

130, julio-diciembre 2012, 661-719, ISSN: 0018-215X, doi: 10.3989/hs.2012.020 
extendía por la ciudad entre los clérigos de rango inferior, aunque aún de manera titubeante. En 1797, se repite una situación más o menos similar, del siguiente tenor: "... se conferenciaron y se determinó que el Señor que entrase de Semana de cantado, aunque tenga precisión de salir fuera de la Ciudad la Semana antes o anteriores, aya de tener el cuidado de encargarla y no se altere el turno; y que esta disposición y cuidado de encargar su Semana no se entienda con los enfermos, y que el que sigue aya de entrar en el turno de enfermo quando se puso enfermo antes de entrar en su turno de Semana, y en el caso de accidente o enfermedad le coja en la actual semana ésta se lebantará por los demás señores, alternando los días».206

También nos topamos con el «Punctto de Quarttanario» en la Congregación de la Criaçon en 1783 y 1787207 y en la parroquia de San Lorenzo a principios del Setecientos. ${ }^{208}$ La situación no era, sin embargo, novedosa en la ciudad. Otros clérigos también disfrutaban de tales sinecuras. En el Hospital del Rey se constata otro ejemplo bien perfilado. Con la indicación al margen «ampliación de enfermería», leemos en sus Actas que «En ese mismo Cavildo se determinó que si algún Sr Capitular, por enfermedad que Dios nro Sr le diese, estubiesse en enfermería y le restasen algunos días al fin de año, se aVisto no espirar dha enfermería sino que se le conceda en el año siguiente hasta concluir y acabar los que le conceden las difiniciones; moviosse estta questión por estar al presente en enfermería el dho Sr Gerónimo Amurrio, y el Cavildo determinó lo que llevo referido». ${ }^{209}$

Este análisis de la «baja laboral» en la Catedral de Burgos supone, en la práctica, el estudio de un caso que pretendemos sea, si se considera oportuno, modélico. La sugerencia de fondo es ver plasmadas en otras realidades catedralicias de Castilla y León, o en otros territorios más lejanos, similares reconstrucciones. Resulta evidente la necesidad de extrapolarlo, tanto en lo geográfico como en lo cronológico, a la realidad capitular burgalesa durante todo el Anti-

206 ADB. San Lesmes. Libro de Actas del Cabildo. Legajo 39/5. Cabildo del 24 de septiembre de 1797 , folio 50 .

${ }^{207}$ ADB. San Lorenzo. Congregación de la Criaçon. Libro de punto y acuerdos de la Comunidad y Congregación (1772-1844). Legajo 2. Cabildo del 30 de junio de 1783, folio 105 y Cabildo del 14 de junio de 1787, folio 142. «Certificación dada por Dn Joseph Vitoriano [Gómez], Cirujano del Cavildo Catedral (...) en la que dixera [ser] mui necesario y útil para la enfermedad habitual que el dho $\mathrm{Sr}$ Prior, Eustaquio Huidobro, padecía, se le concediese por esta Comunidad el punto de Quartanario de treinta días para ir a tomar las aguas de Belascuayn».

208 ADB. San Lorenzo. Libro de acuerdos del Cabildo. Legajo 16. Cabildo del 4 de noviembre de 1701, folio 142. «El Rector mandó juntar a Cavildo (...) [y] propuso que los enfermos abían de ganar en lo distributivo i concordaron todos los Señores de dho Cavildo que se diesen todas las distribuciones a los que estaban enfermos».

${ }^{209}$ Archivo General de Palacio (AGP). Madrid. Patronatos. Hospital del Rey. Libro 7595. Libro de Actas. Cabildo del 31 de diciembre de 1702, folio 42. 
guo Régimen y la extensión del análisis del fenómeno del patitur a la totalidad de las Catedrales castellanas. Los sistemas de protección corporativa capitular en caso de enfermedad se generalizaron a partir del Concilio de Trento, aunque ya era habituales incluso desde mucho antes del siglo XVI. Este primer acercamiento constituye, a la postre, una primera zambullida en esa apasionante temática del «Punctto de Quartanario» y desata más interrogantes que respuestas y más problemáticas que soluciones. La privilegiada y rica documentación de las Actas capitulares burgalesas merecían esta primera aproximación. Queda mucho por hacer y se hará en breve.

\section{BIBLIOGRAFÍA}

Alberola Romá, A. 1985. «Una enfermedad de carácter epidémico en el Alicante del XVIII: las fiebres tercianas». Revista de Historia Moderna 5.

Alberola Romá, A. 1985. «Fiebres, ciencia médica y política sanitaria en el Alicante del Setecientos». Canelobre 4.

Alberola Romá, A. y Bernabé Gil, D. 1998-1999. «Tercianas y calenturas en tierras meridionales valencianas: una aproximación a la realidad médica y social del siglo XVIII». Revista de Historia Moderna 17.

Aldea Vaquero, Q. «Iglesia y Estado en la época del Barroco», en Menéndez Pelayo, R. (Dir.), La España de Felipe IV: Madrid.

Álvarez Santaló, L. C. 2000. ««Vivir como un cura». Algunas precisiones cuantitativas respecto al imaginario social sobre el clero en el siglo XVIII», en Aranda Pérez, F. J. (Coord.), Sociedad y élites..: 101-147, Cuenca.

Alzate Echeverri, A. A. 2008. «Militares, marineros y pobres enfermos. Contribución a la historia del Hospital de San Juan de Dios de Cartagena de Indias (siglo XVIII)». Asclepio 60.

Barrio Gozalo, M. 2005. Iglesia y sociedad en Segovia. Siglos XVI-XIX, Valladolid.

Bartolomé Martínez, G. 2010. Los clérigos a la greña: Alicante.

Bau, A. M. y Canavese, G. F. 2006. «Agua que cura, agua que alimenta». La dietética para sanos y el agua en la sociedad española bajomedieval y moderna». Cuadernos de Historia de España 80.

Beltrán Almazán, C. y Toledano Galera, J. 1988. «El Cabildo de la iglesia Catedral de Jaén en el siglo XVI. Organización y funcionamiento». Boletín de Estudios Giennenses 134.

Benito Aguado, M. T. 2001. La sociedad vitoriana en el siglo XVIII: el clero, espectador y protagonista: 226-229, Bilbao. 
Bernabé Gil, D. 1985.«Tercianas y prevención pública en el Siglo de las Luces: el caso del Bajo Segura». Canelobre 4.

Blanco Díez, A. 1945-1946. «Los deanes de la Catedral de Burgos». Boletín de la Comisión Provincial de Monumentos» 90-94.

Bravo Lozano, J. 2005.«Cura rico/cura pobre. Notas sobre rentas eclesiásticas en el Madrid de fines del siglo XVII», en Suárez Grimón, V., Lobo Cabrera, M. y Martínez Ruiz, E. (Coords.), Iglesia y sociedad en el Antiguo Régimen, Actas de la III Reunión Científica de Historia Moderna de la Asociación Española de Historia Moderna: vol. 1, 129-140, Las Palmas de Gran Canaria.

Brockliss, L. y Jones, C. 1997. The Medical World of Early Modern France, Cambridge, Lindemann, A. M. 1996. Health and Healing in Eighteenth Century Germany, Baltimore y Londres.

Cabeza Rodríguez, A. 1997. La vida en una Catedral del Antiguo Régimen: 54-55, Palencia.

Cabeza Rodríguez, A. 1996. Clérigos y señores. Política y religión en Palencia en el Siglo de Oro: 327, Palencia.

Canovas Botía, A. 1994. Auge y decadencia de una institución eclesial: el Cabildo Catedral de Murcia en el siglo XVIII. Iglesia y Sociedad: 199-202, Murcia.

Capel Sáez, H. 1998-1999. «Medicina y clima en la España del siglo XVIII». Revista de Geografía 32-33.

Carmona García. J. I. 2000. Crónica urbana del malvivir (s. XIV-XVII). Insalubridad, desamparo y hambre en Sevilla, Sevilla.

Carmona Urán, G. 1954. Historia de las viejas rúas burguenses: Burgos.

Caro Puértolas, B. 2003. «Pasado y presente de los Balnearios en Extremadura». Revista de Estudios Extremeños 59/1.

Chaunu, P. 1973. «Un nouveau champ pour l'histoire sérielle: le quantitatif au troisième niveau», Méthodologie de l'histoire et des sciencies humaines, Mélanges en l'honneur de Fernand Braudel: tomo II : 105-125, París.

Chaussinand-Nogaret, G. 1977. «Médecins, médecine et société en France aux XVIIIe et XIXe siècles», Annales ESC 32/5.

Cipolla, C. M. 1993. Contra un enemigo mortal e invisible, Barcelona, Crítica.

Coronas Vida, L. J. 1986-1987. «Los miembros del Cabildo de la Catedral de Jaén (1700-1737)» Chrónica Nova 15.

Díaz Pintado, J. 1991.«Epidemias de paludismo en La Mancha del XVIII». Cuadernos de Historia Moderna 12.

Díaz Rodríguez, A. J. 2009. «Las casas del deán don Juan de Córdoba: Lujo y clientela en torno a un capitular del Renacimiento». Hispania Sacra 123. 
Díaz Rodríguez, A. J. 2006. «Entre parientes. Modelos de formación de dinastías familiares en el Cabildo catedralicio cordobés (ss. XVI-XIX)», en Congreso Internacional «Las élites en la Época Moderna: La Monarquía Española»: Córdoba.

Domínguez Ortiz, A. 1964. «Absentismo eclesiástico en Canarias». Anuario de Estudios Atlánticos 10.

Fagan, B. 2009. La pequeña edad de hielo. Cómo el clima afectó a la historia de Europa, 1300-1850: Barcelona.

Fernández Doctor, A. 1997. «Médicos y cirujanos de Zaragoza en la Edad Moderna». Dynamis 17.

Fernández García, A. 1991. «La enfermedad como indicador social. Consideraciones metodológicas», en Castillo, S. (Coord.), La historia social en España. Actualidad y perspectivas: 401-428, Madrid.

Fronfría Díaz, J., Jiménez Artacho, C. y Fernández Pérez, J. 2001. «La corteza de la quina. Un remedio universal», Estudios de Historia das Ciencias e das Técnicas: tomo II, Pontevedra.

Frías Núñez, M. 2003. «El discurso médico a propósito de las fiebres y de la quina en el Tratado de las calenturas (1751) de Andrés Piquer». Asclepio 55.

Frías Núñez, M. 2003. «El discurso médico a propósito de las fiebres y de la quina en el Tratado de las calenturas (1751) de Andrés Piquer». Asclepio 55/1.

García-Cuevas Ventura, J. 1996.El Cabildo catedralicio cordobés desde la Revolución a la Restauración (1788-1882): 36-37: Córdoba.

García Guerra, D. 1985. «El ejercicio médico en el Hospital Real de Santiago en el siglo XVIII», en Peset Reig, J. L. (Ed.), La ciencia moderna y el conocimiento del Nuevo Mundo.

Gelfand, T. 1980. Professionalizing Modern Medicine, Londres.

Gómez Díaz, D. y Gómez Díaz, M. J. 2003. «Almería ante el contagio. La práctica sanitaria del siglo XVIII». Dynamis 23.

González Cruz, D. 1993. Religiosidad y ritual de la muerte en la Huelva del siglo de la Ilustración: 21-22, Huelva.

Granjel. M. 2002: «Médicos y cirujanos en Extremadura a finales del siglo XVIII».Dynamis 22.

Guerra, F. 1977. «El descubrimiento de la quina» Medicina e Historia 69.

Gutiérrez-Cortines Corral, C. 1990. «La arquitectura del Agua: Los Balnearios del Mar Menor». Imafronte 6-7.

Gutiérrez Rodilla, B. M. 1999. «Sobre la hidrología médica en la España barroca». Medicina e Historia 3. 
Hernando, T. 1982. «La quina en el siglo XVII», Dos estudios históricos (Vieja y Nueva Medicina): Madrid.

Iglesias Rouco, L. S. 1978. Arquitectura y urbanismo de Burgos bajo el reformismo ilustrado (1747-1813): Burgos.

Irigoyen López, A. 2000. Entre el cielo y la tierra, entre la familia y la institución. El Cabildo de la Catedral de Murcia en el siglo XVII: Murcia.

Lafuente, A., Puerto Sarmiento, F. J. y Calleja Folguera, M. C. 1988. «Los profesionales de la sanidad tras su identidad en la Ilustración española», en Sánchez Rón, J. M. (Ed.), Ciencia y Sociedad en España: de la Ilustración a la Guerra Civil.

León Sanz, P. 2002. «La consulta médica. Una práctica de la medicina en el siglo XVIII». Dynamis 22.

López Gómez, J. M. 1993. «Los médicos del Cabildo catedralicio de Burgos en el siglo XVIII». Boletín de la Institución Fernán González 207.

López Gómez, J. M. 1996. Cirugía ilustrada en Burgos: la figura y la obra de José Victoriano Gómez (1773-1819), Burgos, Institución Fernán González Academia Burgense de Historia y Bellas Artes.

López Gómez, J. M. 1996. Salud y enfermedad en el Burgos de la segunda mitad del siglo XVIII, Burgos.

López Gómez, J. M. 1997. «La asistencia sanitaria a militares enfermos en el Burgos del último tercio del siglo XVIII». Boletín de la Institución Fernán González 21.

López Gómez, J. M. 1998. «La enfermedad del canónigo Calderón. Una historia clínica de demencia en el Burgos de principios del siglo XVIII». Revista de la Asociación Española de Neuropsiquiatría 66.

López Gómez, J. M. 1999. «Los profesionales sanitarios de la ciudad de Burgos en 1740». Boletín de la Institución Fernán González 218.

López Gómez, J. M. 2005. «Razón y locura en el Burgos de la Ilustración. El caso del marqués de Lorca», en Estudios de Historia y Arte. Homenaje al profesor D. Alberto C. Ibáñez Pérez: 177-181, Burgos.

Mateu Tortosa, E. 1987. Arroz y paludismo. Riqueza y conflictos en la sociedad valenciana del siglo XVIII, Valencia.

Montiel, L. (Coord.), La salud en el estado de bienestar: análisis histórico: 107-131, Madrid.

Moretón Alonso, M. 1993. Las profesiones sanitarias en Castilla y León (siglo XVIII). Análisis sociológico y estadístico, Valladolid.

Morgado García, A 1989. Iglesia y sociedad en el Cádiz del siglo XVIII: 101, Cádiz. 
Morgado García, A. 2000. «Vida de canónigo. Percepción, origen y status de vida del alto clero durante el Antiguo Régimen», en Aranda Pérez, F. J. (Coord.): 77-100.

Núñez Roldán, F. 1988. «Enfermedades, hospitalidad y terapéutica en las comarcas onubenses a fines del Antiguo Régimen». Huelva en su historia 2.

Ortiz Gómez, T., Quesada Ochoa, C. y Astrain Gallart, M. 1994. «El Catastro de Ensenada como fuente para el estudio de las profesiones sanitarias en la España del siglo XVIII», en Carrillo Martos, J. L. y Olagüe de Ros, G. (Eds.), Actas del 33 Congreso Internacional de Historia de la Medicina: 712-713, Sevilla.

Ortiz Gómez, T., Quesada Ochoa, C. y Astrain Gallart, M. 1995. «Profesionales de la salud en la Almería del siglo XVIII, según el Catastro de Ensenada», Actas del II Congreso de Historia de Andalucía, Historia Moderna, tomo I: 511-520, Córdoba.

Peñafiel Ramón, A. 1995. «Iglesia, poder y perpetuación en la España del siglo XVIII: la escuela de niños de Villanueva del Campo», en Hernández Franco, J., Familia y poder. Sistemas de reproducción social en España (siglos XVI al XVIII): Murcia.

Perdiguero Gil, E. 2002. «Con medios humanos y divinos»: la lucha contra la enfermedad y la muerte en Alicante en el siglo XVIII», Dynamis 22.

Perdiguero Gil, E. y Bernabeu Mestre, J. 1995.«La asistencia médica pública en el Alicante del siglo XVIII: los médicos de la Ciudad». Canelobre 29/30.

Pérez Fernández, M. R. y Novoa Castro, B. 2002. «Historia del agua como agente terapéutico». Fisioterapia 24.

Pérez Medina, T. V. 1991. «Arròs, paludisme i població a la comarca de l'Horta. L'epidèmia de 1784». Afers 11-12.

Pérez Moreda, V. 1980. Las crisis de mortalidad en la España interior. Siglos XVI-XIX: 74-76 y 336-350.

Pérez Moreda, V. 1982. «El paludismo en España a fines del siglo XVIII: la epidemia de 1786». Asclepio 34.

Pérez Moreda, V. 1984. «Crisis demográficas y crisis agrarias: paludismo y agricultura en España a fines del siglo XVIII», en Congreso de Historia Rural. Siglos XV al XIX: 333-354, Madrid.

Pérez Samper, M. A. 1997. «Fiesta y alimentación en la España Moderna: el banquete como imagen festiva de abundancia y refinamiento». Espacio, Tiempo y Forma 10.

Perrenoud, A. 1975. «L'inégalité sociale devant la mort a Genève au XVII ${ }^{\mathrm{e}}$ siècle». Population (French Edition) 30.

Peset Reig, M. 1972. «Cultivos de arroz y paludismo en la Valencia del siglo XVIII». Hispania 121. 
Peset Reig, M. 1978. «Epidemias y sociedad en la España del fin del Antiguo Régimen». Estudios de Historia Social 4.

Peset Reig, M. y J. L. 1979. «Tercianas y ciencia médica en el Setecientos valenciano», en I Congreso de historia del País Valenciano: vol. III, 685-694: Valencia.

Peset Reig, L. L. (Dir.). 2002. Historia de la ciencia y de la técnica en la corona de Castilla, IV, Siglo XVII: Valladolid.

Peset Reig, J. L. 2008. «Clérigos y médicos ante la muerte», Vía Spiritus, 15.

Peter, J. P. 1972. «Malades et maladies à la fin du XVIIIe siècle», en Le Roy Ladurie, E., Desaive, J. P. y otros, Médecins, climat et epidémies à la fin du XVIII siècle: París.

Pons i Sierra, L. 2001. «L'epidèmia de terçanes de l'any 1785 a Agramunt». URTX, Revista cultural de l'Urgell 14.

Quintana Andrés, P. C. 2003. A Dios rogando y con el mazo dando. Fe, poder y jerarquía en la Iglesia canaria. El Cabildo Catedral de Canarias entre 1483-1820: 165-170, Las Palmas de Gran Canarias.

Quintana Andrés, P. C. 2004. Finis gloriae mundi. Ideología y sociedad en Canarias. Los prebendados del Cabildo Catedral durante el Antiguo Régimen (1483-1820): 38-40, Bilbao.

Ramsey, M. 1988. Professional and popular medicine in France, 17701830, Cambridge.

Riera Palmero, J. 1980. José Masdevall y la medicina española ilustrada. (Enseñanza, epidemia y guerra a finales del siglo XVIII), Valladolid.

Riera Palmero, J. 1974.«Organización hospitalaria militar en la España ilustrada. (Las «Ordenanzas» de 1739)» Asclepio 26-27.

Riero Palmero, J. 1984. Fiebres y paludismo en la España ilustrada: Félix Ibáñez y la epidemia de La Alcarria, 1784-1792, Valladolid.

Rodríguez Sánchez, A. 2000. «La clientela capitular del deán de Coria a finales del siglo XVI», en Aranda Pérez, F. J. (Coord.), Sociedad y élites...: Cuenca.

Rodríguez Sánchez, J. A. 2007. «Agua que aún mueve molino: aproximación a la historia balnearia». Anales de Hidrología Médica 2.

Rojo Vega, A. 1994. «Los médicos vallisoletanos del siglo XVII. Status y consideración social», en Historia y Medicina en España. Homenaje al Profesor Luis S. Granjel.

Rosa Jorge, M. C. y Mosso Romeo, M. A. 2004. «Historia de las aguas mineromedicinales en España». Observatorio Medioambiental 7. 
Rosado Batea, I. y Vidal Casero, M. C. 1985.«Paludismo en el siglo XVIII: graves epidemias de tercianas afectaron al este español en los años 1784 y 1785», en IV Congrés d'Història de la Medicina Catalana: vol. I, 325-332, Poblet.

Saavedra Fernández, P. 1979. Economía rural antigua de la montaña lucense: el Concejo de Burón: 51, Santiago de Compostela.

Sánchez Granjel, L. 1979. La medicina española del siglo XVIII, Salamanca.

Sáez Gómez, J. M. y Marset Campos, Pedro. 1993. «Profesionales sanitarios en la Murcia del siglo XVIII. Número, evolución y distribución». Asclepio 45/2.

Sáez Gómez, J. M. y Marset Campos. 2000. «Teoría académica y práctica ciudadana en el paludismo. Las causas de las enfermedades endémicas en Murcia durante el siglo XVIII desde la perspectiva de la administración local». Asclepio 52.

Sánchez González, R. 2000. Iglesia y sociedad en la Castilla Moderna: el Cabildo catedralicio de la Sede primada (siglo XVII): 47-48, Cuenca.

Sanz de la Higuera, F. J. 2012. «Aproximación a los problemas de visión y el uso de anteojos en el Burgos de mediados del siglo XVIII». El Futuro del Pasado 3.

Sanz de la Higuera, F. J. 2009. «Carrera eclesiástica y algunos deslices de Felipe del Hoyo y Pedro Celestino Tomé, arcedianos de Burgos (1731-1784)». Hispania Sacra 124.

Sanz de la Higuera, F. J. 2009. «Aproximación a la locura en el Setecientos burgalés. Cerebros, humores y economías en desequilibrio». Investigaciones Históricas 29.

Sanz de la Higuera, F. J. 2009. «La librería del canónigo lectoral Prieto Bustamante. Libros y mesas de trucos a la greña. Burgos (1749-1766)», en Álvarez Santaló, L. C. (Coord.), Estudios de Historia Moderna en homenaje al profesor Antonio García-Baquero: 639-659, Sevilla.

Sanz de la Higuera, F. J. (2009). «La temible f(r)actura de la muerte. Fallecer en el Burgos del Setecientos». Cuadernos de Investigación Histórica 23.

Sanz de la Higuera, F. J. 2006. «Seminario de San Nicolás (Burgos, 1743): una rectoría apetecible, un litigio aborrecible». Boletín de la Institución Fernán González 232.

Sanz de la Higuera, F. J. 2005. «Cebada, mulas, caballos, carruajes y habas. La Catedral de Burgos en el Setecientos». Hispania Sacra 116.

Sanz de la Higuera, F. J. 2005. «Obras en Barrantes (1747-1750)». Boletín de la Institución Fernán González 230.

Silva Prada, N. 2002. «El uso de los baños temascales en la visión de dos médicos novohispanos. Estudio introductorio y transcripción documental de los informes de 1689». Historia Mexicana 52/2. 
Sobrevía Clavera, A. 2004.«El cultivo del arroz de secano en Cataluña (17781839). Una propuesta agronómica al problema del paludismo». Asclepio 56.

Soler Pascual, E. 1994. «Perfil biográfico de Miguel Javier de Beramendi y Eleta, deán de la Catedral de Valencia (1782-1833)», en Martínez Ruiz, E. y Suárez Grimón, V. (Eds.), Iglesia y sociedad en el Antiguo Régimen, III Reunión científica de la asociación Española de Historia Moderna, v. I. Las Palmas de Gran Canaria, 1994.

Villacorta Rodríguez, T. 1974. El Cabildo Catedral de León. Estudio histórico-jurídico, siglos XIII-XIX. León.

Villacorta Rodríguez, T. 1974. «Causas que eximen de residencia y asistencia (...) c) Enfermos y convalecientes», El Cabildo Catedral de León. Estudio histórico-jurídico, siglos XII-XIX: 266-269, León.

Zarzoso i Orellana, A. 1998.1999. «¿Obligación moral o responsabilidad política? Las autoridades borbónicas en tiempo de epidemias en la Cataluña del siglo XVIII». Revista de Historia Moderna 17. 